NBER WORKING PAPER SERIES

\title{
THE ABOLITION OF IMMIGRATION RESTRICTIONS AND THE PERFORMANCE OF FIRMS AND WORKERS: EVIDENCE FROM SWITZERLAND
}

\author{
Andreas Beerli \\ Jan Ruffner \\ Michael Siegenthaler \\ Giovanni Peri \\ Working Paper 25302 \\ http://www.nber.org/papers/w25302 \\ NATIONAL BUREAU OF ECONOMIC RESEARCH \\ 1050 Massachusetts Avenue \\ Cambridge, MA 02138 \\ November 2018, Revised January 2020
}

The present study builds on the insights of two papers that were concurrently written: Beerli and Peri (2018) and Ruffner and Siegenthaler (2017). The first paper analyzed the employment, wage, mobility and occupational specialization effects of the labor market liberalization in Switzerland. The second studied the firm-level impact of the same reform, establishing its effects on the employment of foreigners within firms and on size, productivity, innovation, location and staffing decisions of firms. We are indebted to the editor and three referees for unusually helpful comments. We also thank the following for their many helpful comments and suggestions on the prior versions of this paper: Andrea Ariu, Matthias Bannert, Christoph Basten, Richard Blundell, Marius Brülhart, David Card, Matz Dahlberg, Kathrin Degen, David Dorn, Christian Dustmann, Peter Egger, Sandro Favre, Ingrid Hägele, Dominik Hangartner, Fred Henneberger, Jennifer Hunt, Boris Kaiser, Daniel Kaufmann, Felix König, Johannes Kunz, Stephan Kyburz, Rafael Lalive, Andrea Lassmann, Guy Michaels, Tobias Müller, Dina Pomeranz, Kjell Salvanes, Lukas Schmid, Daphné Skandalis, Andrin Spescha, Uta Schönberg, Andrin Spescha, Jan Stuhler, JanEgbert Sturm, Fabian Waldinger, Martin Wörter, Dean Yang, Josef Zweimüller, Alexandre Ziegler, and Fabrizio Zilibotti. The views expressed herein are those of the authors and do not necessarily reflect the views of the National Bureau of Economic Research.

NBER working papers are circulated for discussion and comment purposes. They have not been peer-reviewed or been subject to the review by the NBER Board of Directors that accompanies official NBER publications.

(C) 2018 by Andreas Beerli, Jan Ruffner, Michael Siegenthaler, and Giovanni Peri. All rights reserved. Short sections of text, not to exceed two paragraphs, may be quoted without explicit permission provided that full credit, including $\odot$ notice, is given to the source. 
The Abolition of Immigration Restrictions and the Performance of Firms and Workers: Evidence from Switzerland

Andreas Beerli, Jan Ruffner, Michael Siegenthaler, and Giovanni Peri

NBER Working Paper No. 25302

November 2018, Revised January 2020

JEL No. F22,J22,J24,J61

\section{ABSTRACT}

We study a reform that granted European cross-border workers free access to the Swiss labor market and had a stronger effect on regions close to the border. The greater availability of crossborder workers increased foreign employment substantially. Although many cross-border workers were highly educated, wages of highly educated natives increased. The reason is a simultaneous increase in labor demand: the reform increased the size, productivity, and innovation performance of skill-intensive incumbent firms and attracted new firms, creating opportunities for natives to pursue managerial jobs. These effects are mainly driven by firms that reported skill shortages before the reform.

Andreas Beerli

KOF Swiss Economic Institute ETH Zurich

Leonhardstrasse 21

CH-8092 Zurich

Switzerland

beerli@kof.ethz.ch

Jan Ruffner

KOF Swiss Economic Institute ETH Zurich

Leonhardstrasse 21

CH-8092 Zürich

Switzerland

jan_ruffner@hotmail.com
Michael Siegenthaler

KOF Swiss Economic Institute ETH Zurich

Leonhardstrasse 21

CH-8092 Zürich, Switzerland

Switzerland

siegenthaler@kof.ethz.ch

Giovanni Peri

Department of Economics

University of California, Davis

One Shields Avenue

Davis, CA 95616

and NBER

gperi@ucdavis.edu 


\section{Introduction}

Policies that open the labor market to foreigners are often opposed by natives on the ground that they could harm their labor market opportunities. Yet, free mobility of workers means more opportunities for businesses to hire a wider variety of skills. Firms usually welcome a less restricted access to foreign workers. ${ }^{1}$ If firms benefit from open borders through increased productivity and growth, this may counteract the effects of increased labor market competition and expand job opportunities for native workers. However, our knowledge on how immigration policies affect firms' success, and whether such effects shape the labor market effects of immigration, is limited. This study attempts to extend our knowledge on the labor market effects of and firms' responses to opening the border.

We study a far-reaching and controversial policy change: the complete removal of all immigration restrictions for workers from the European Union (EU) in Switzerland when the latter introduced the principle of the "free movement of persons." This principle allows EU citizens to access jobs with no restrictions within the territory of member states. This paper analyzes the consequences of one central aspect of the reform: the removal of all preexisting restrictions on European cross-border workers (CBW). CBW are employed in Switzerland, live in its neighboring countries (Italy, Germany, Austria and France), and commute across the border for work. CBW were already a sizable group in Swiss regions near the border prior to the policy changes. However, there were several administrative hurdles to hiring them. For example, CBW were subject to a bureaucratic process that aimed at ensuring that firms only hire them if they did not find an equally qualified resident worker (the so called priority requirement). These prior restrictions were gradually abolished after the announcement of the reform in 1999. The priority requirement was abolished in 2004, and CBW thus gained free access

\footnotetext{
${ }^{1}$ In a survey by BAK (2013), 75\% of all employers in Switzerland, the country analyzed in this paper, consider access to foreign workers as "important," "very important," or even "indispensable" for their competitiveness and profits.
} 
to Swiss labor markets close to the border.

How did the greater availability of CBW affect Swiss workers and firms? To study this question, we leverage the fact that the greater availability of CBW had stronger effects on firms and native workers close to the border. In locations farther than 30 minutes driving distance from the border, employment of CBW remained negligible. One reason is that CBW could not be employed outside the so-called "border region" until 2007-a clearly defined set of municipalities close to the border. Another reason is that CBW rarely work in places located far away from the border simply because they are commuters from abroad and not residents of Switzerland. Empirically, we thus compare changes in outcomes in labor markets close to the border with changes in outcomes in labor markets further away from it, distinguishing a pre-treatment (before 1999), a transitional (1999-2003), and a free movement phase (2004 onward). This Difference-in-Differences (DiD) strategy has important advantages compared to many previous studies in the immigration literature because both the increase in the availability of foreign workers and its uneven regional impact are a direct consequence of the exogenous change in the policy related to $\mathrm{CBW} .^{2}$ Our analyses are based on data from a large-scale employer survey conducted between 1994 and 2010, micro-level panel data from the Business Censuses 1991-2011 covering the universe of Swiss establishments, and a series of innovation surveys conducted between 1996 and 2013.

We first show that, between 1999 and 2010, the labor market liberalization for CBW produced a net increase of foreign workers equal to 10 percentage points of the total 1998 employment in municipalities within 15 minutes travel time to the border. The increase was most pronounced in the

\footnotetext{
${ }^{2}$ Studies on the firm and labor market effects of immigration are typically based on the so-called area approach, and isolate supply-driven variation in immigration into regional labor markets by applying a "shift-share" instrumental variable approach. The approach hinges on the assumption that historical immigrant settlement patterns are uncorrelated to the regional distribution of current unobserved labor demand shocks. This assumption is not always plausible (see Jaeger et al., 2019, for a discussion).
} 
post-2004 period and two thirds of all new CBW were highly educated. We also observe a small disproportionate increase in employment of permanent resident immigrants close to the border. While Switzerland also removed all barriers for EU immigrants when introducing free movement of persons, this aspect of the reform affected all regions uniformly, independently of their distance to the national border. The finding thus suggests that the greater availability of CBW complemented and crowded in resident immigrants from EU countries.

We then document that the greater availability of CBW did not have a statistically significant negative effect on average employment or wages of Swiss native workers. In fact, we find that the reform increased wages of highly educated native workers by around $5 \%$. If anything, their employment increased as well. As many of the incoming workers were highly educated, these results cannot be rationalized by a simple model with high- and lowskilled labor in which immigration represents a pure supply shift (as in, e.g., Borjas, 2003). They are also striking considering that CBW almost certainly generate weaker consumption-side effects (on demand for local nontradable services) than normal immigrants because they do not relocate to Switzerland.

Based on a search and matching framework with heterogeneous labor, we argue that a greater availability of CBW can have limited displacement effects because it may make it easier for firms to find certain skilled workers that were hard to find before, thus generating incentives to create new jobs for skilled workers. In such a framework, the positive wage effects on highly educated natives can be rationalized if the policy additionally increased productivity, innovation performance, or capital formation of firms.

We present four pieces of evidence in line with these predictions. First, we show that the inflow of CBW was largest in high-tech manufacturing and the knowledge-intensive business service sector - i.e. industries that depend on the availability of skilled workers. We find that the positive wage ef- 
fects on natives are nevertheless concentrated in these skill-intensive sectors because the reform increased labor productivity of incumbent firms in the sectors. Second, we show that the reform boosted firm expansion by relaxing prior constraints to recruit skilled workers. In particular, we observe substantial gains in labor productivity in incumbent firms that reported to be constrained by a lack of specialized personnel or limited by labor market regulation for foreign workers before the reform. Third, we show that the free movement policy increased R\&D employment, patent applications, and product innovations. Again, these effects are concentrated in firms that reported scarcity of R\&D workers before the reform. Fourth, we find evidence for relatively quick capital adjustments to immigration: the share of new establishments increased by 4 percentage points in the regions closest to the border. In sum, these firm effects created opportunities for natives to grow professionally and their likelihood to work in top managerial positions increased. These transitions into high-paying management explain roughly one third of the positive wage effects for highly educated natives.

We provide a large set of robustness checks that corroborate the causal interpretation of these findings. Most importantly, we show that our results are not driven by firms and industries that were most affected from the trade liberalizations between Switzerland and the EU that occurred largely simultaneously with the changes in the commuting policy. We also discuss whether regions close to the border may have partly grown at the expense of regions further away. Indeed, some of our firm-level findings are consistent with such an interpretation. However, we do not find evidence for a systematic mobility response of natives that would likely arise if one region benefited at the expense of other regions. Although these results are no ultimate empirical proof, they reduce concerns that our DiD estimates mainly reflect relative rather than absolute causal effects.

Ours is one of the first studies exploiting changes in policies for cross- 
border commuters to study the effects of immigration. ${ }^{3}$ The closest precursor to this paper is Dustmann et al. (2017) who analyze the labor market effects of the opening of Germany's labor market to Czech CBW workers in 1991. Dustmann et al. (2017) show that the inflow of Czech workers had strong negative short-run effects on native employment and smaller but significant negative effects on native wages. We believe that the strikingly different consequences for natives of the opening of the German labor market are due to differences in the design and in economic circumstances of the policy change compared to the one in Switzerland. First, the Czech inflow was mainly composed of less-educated workers hired in relatively low-skill-intensive industries. In contrast, many new CBW in the Swiss case were highly skilled, and the beneficial effects on natives arose in industries dependent on skilled workers. Second, the policy change in Germany was unexpected, affected regions that had not experienced significant immigrant inflows previously and that had a less developed industrial structure. In contrast, the Swiss policy change was announced early and phased-in gradually, and it had the strongest impact on regions that were used to foreign workers and had a more competitive industry structure. Presumably, the firms were more prepared to match the new workers to jobs in an efficient way. Finally, the episode studied by Dustmann et al. (2017) took place when both Germany and the Czech Republic underwent a major economic transition. In contrast, Switzerland opened its labor market at a time when the unemployment rate was very low and demand for skilled workers was high. Relaxing the constraints on the supply of skilled workers appears to have benefited firms that had suffered from lack of skilled labor before the reform.

This paper makes four main contributions to the literature. First, it shows that firms' responses to changes in the availability of skilled labor determine the labor market effects of opening the border. Our labor market

\footnotetext{
${ }^{3}$ The idea to exploit the changes in Switzerland's commuting policies to study the effects of immigration was also pioneered in two policy reports by Henneberger and Ziegler (2011) and Losa et al. (2014).
} 
findings can only be rationalized when accounting for firms' productivity, capital investment, innovation and specialization responses. So far, "there is very little tradition for considering firms in analyses of immigration" (Kerr et al., 2015, p. S148). In fact, very few previous papers analyzed firm and labor market effects of immigration jointly. ${ }^{4}$ Second, our study is one of the first to rigorously evaluate the consequences of a policy that permanently removed all barriers to labor market access for (a group of) foreign workers. Our variation is thus different to many other quasi-experimental papers that focus on temporary push-driven surges in immigration such as the Mariel Boatlift where a large number of immigrants are exogenously placed in specific local labor markets. In contrast, the permanent change in immigration policy analyzed here rather leads to a gradual matching of new CBW to jobs in Switzerland, and plausibly has a strong direct effect on firms' incentives to create jobs. Third, our study directly informs policy makers about the potential economic benefits of the principle of free movement of persons. This is highly relevant against the background of mounting opposition to free labor mobility in Europe, which culminated in 2016 with Britain's decision to leave the EU. Fourth, our study contributes to the literature on the impacts of skilled immigration on productivity, innovation, and production technology in the receiving country (see Kerr et al., 2015, for an overview). Studies at the regional level (e.g., Hunt and Gauthier-Loiselle, 2010; Peri et al., 2015a,b) or that focus on inventors (Moser et al., 2014) tend to find positive impacts on productivity and innovation. Firm-level studies examining these links are still rare, focus mostly on the $\mathrm{US}^{5}$, and reach conflicting conclusions. $^{6}$

\footnotetext{
${ }^{4}$ Examples of empirical papers that study the labor market and firm effects of immigration jointly include Dustmann and Glitz (2015) and Aksu et al. (2018). Waugh (2018) provides a theoretical analysis how the dynamics of the firm affect economic outcomes from changes in immigration policy.

${ }^{5}$ The exceptions are Paserman (2013), who examines how immigration from the former Soviet Union affected Israeli manufacturing firms in the 1990s, and Mitaritonna et al. (2017), who study the impact of the local concentration of immigrants on productivity of French manufacturers.

${ }^{6}$ The US studies generally focus on evaluating the effects of the H-1B program. The
} 


\section{The immigration reform}

The process of opening the Swiss labor market to citizens from the EU started with the signing of the bilateral agreements between the EU and Switzerland on June 21, 1999. The so called "Agreement on the Free Movement of Persons" (AFMP) introduced free worker mobility among the signing countries. The relevant details of this agreement were publicly announced in Switzerland in late 1998. The agreement was then discussed by the Swiss parliament. After the treaty had been signed, it required the approval of the Swiss electorate, which accepted it in a national referendum in May 2000 with an approval rate of $67.2 \%$. The European parliament and each EU member state also approved the treaty in year 2000. The AFMP was enacted in June 2002, one-and-a-half years later than planned at the time of the first announcement. Given the timing of the reform, anticipatory effects of the reform are possible from 1999 onward. $^{7}$ Given the political circumstances, it appears very unlikely that the local economic conditions of the regions most affected by the agreements were a consideration in the timing and the content of the treaty. ${ }^{8}$

Table 1 provides a time-line for the stepwise introduction of free movement of persons. The table distinguishes three reform phases (the pre-reform,

results in Ghosh et al. (2014) and Kerr and Lincoln (2010) suggest that greater access to $\mathrm{H}-1 \mathrm{~B}$ workers generally increases the size, productivity, and innovation performance of firms that rely heavily on $\mathrm{H}-1 \mathrm{~B}$ visas. Doran et al. (2015), on the other hand, find that winning an additional $\mathrm{H}-1 \mathrm{~B}$ worker has no effect on patenting and firm size but increases profits and crowds out resident workers. Kerr et al. (2015) find that hiring young skilled immigrants increases firms' skill intensity but their evidence regarding firm size is inconclusive. Similarly, Olney (2013) finds little impact of (low-skilled) immigration on employment within existing establishments.

${ }^{7}$ The relevant details of the reform were not public knowledge before 1998 and the success of the negotiations was uncertain prior to a breakthrough achieved only in 1998 . In fact, even in 1997 and early 1998, several members of the Swiss parliament expressed their concerns that the negotiations could fail.

${ }^{8}$ One reason is that the federal government, not the cantons, negotiated over the AFMP. Another reason is that introducing the free movement of persons was not championed by the Swiss government but a political concession to the EU. At the beginning of the negotiations in 1993 that led to these agreements, the Swiss government tried to avoid a full-fledged version of free worker mobility. As the EU insisted on full labor mobility, a breakthrough in the negotiations was only reached when both parties agreed that the free labor mobility would be implemented step-wise and included further safety measures. 
Table 1: The different phases of the introduction of free movement of workers

\begin{tabular}{|c|c|c|c|c|c|}
\hline \multirow[b]{2}{*}{ Phase } & \multirow[b]{2}{*}{ Year } & \multirow[b]{2}{*}{ Event } & \multicolumn{2}{|c|}{ Cross-border workers } & \multirow{2}{*}{$\begin{array}{c}\text { Immigrants } \\
\text { Both regions }\end{array}$} \\
\hline & & & Border region & Non-border region & \\
\hline \multirow[t]{4}{*}{ Pre-reform } & 1995 & & \multirow{4}{*}{$\begin{array}{l}\text { Admission process } \\
\text { (priority requirement), } \\
\text { further restrictions }\end{array}$} & \multirow[t]{4}{*}{ No access } & \multirow{7}{*}{$\begin{array}{l}\text { Admission process, } \\
\text { annual quotas, } \\
\text { further restrictions }\end{array}$} \\
\hline & 1996 & & & & \\
\hline & 1997 & & & & \\
\hline & 1998 & Announcement & & & \\
\hline \multirow{4}{*}{$\begin{array}{l}\text { Transition } \\
\text { phase }\end{array}$} & 1999 & AFMP signed & \multirow{3}{*}{$\begin{array}{l}\text { Anticipatory } \\
\text { effects possible }\end{array}$} & & \\
\hline & 2000 & Referendum & & & \\
\hline & 2001 & & & & \\
\hline & $\begin{array}{l}2002 \\
2003\end{array}$ & AFMP enacted & $\begin{array}{l}\text { Abolition of } \\
\text { further restrictions }\end{array}$ & & $\begin{array}{l}\text { Higher quotas, } \\
\text { further changes }{ }^{1}\end{array}$ \\
\hline \multirow{5}{*}{$\begin{array}{l}\text { Free movement } \\
\text { phase in border } \\
\text { region }\end{array}$} & 2004 & Liberalization & \multirow[t]{5}{*}{ Free } & & Abolition of \\
\hline & 2005 & in border region & & & admission process \\
\hline & 2006 & & & & \\
\hline & 2007 & Full liberalization & & Free & Free \\
\hline & 2008 & & & & \\
\hline
\end{tabular}

the transition, and the free movement phase) and two types of foreign workers: permanent resident immigrants (or immigrants for short) and CBW. The shading of the table highlights the restrictiveness of the regulations for the respective worker category. The table shows that permanent resident immigrants from EU countries had been subject to yearly national quotas set by the federal government before the reform and to an admission process very similar to the one for CBW detailed below. These restrictions were removed starting in 2002. EU immigrants gained free and full access to the Swiss labor market with the abolition of annual quotas in 2007. Legally, these changes affected all regions in Switzerland equally.

The table also shows the timing for lifting the barriers on hiring and employment of CBW. These changes only affected municipalities in the border region $(\mathrm{BR})$ in the years between 1999 and 2004. The reason is that employment of CBW remained restricted to BR until 2007, as it was before the reform. Figure 1 illustrates the geographical split of Switzerland into the BR (in grey) and the rest of Switzerland, the non-border region (NBR, in white). The BR had been defined in bilateral agreements between Switzerland and its neighboring countries signed between 1928 and 1973. The frontier between BR and NBR remained unchanged in the course of the reform and it does not follow cultural or religious border, nor cantonal or 
other administrative borders.

Figure 1: Municipalities in the border and non-border region and travel distance to the border

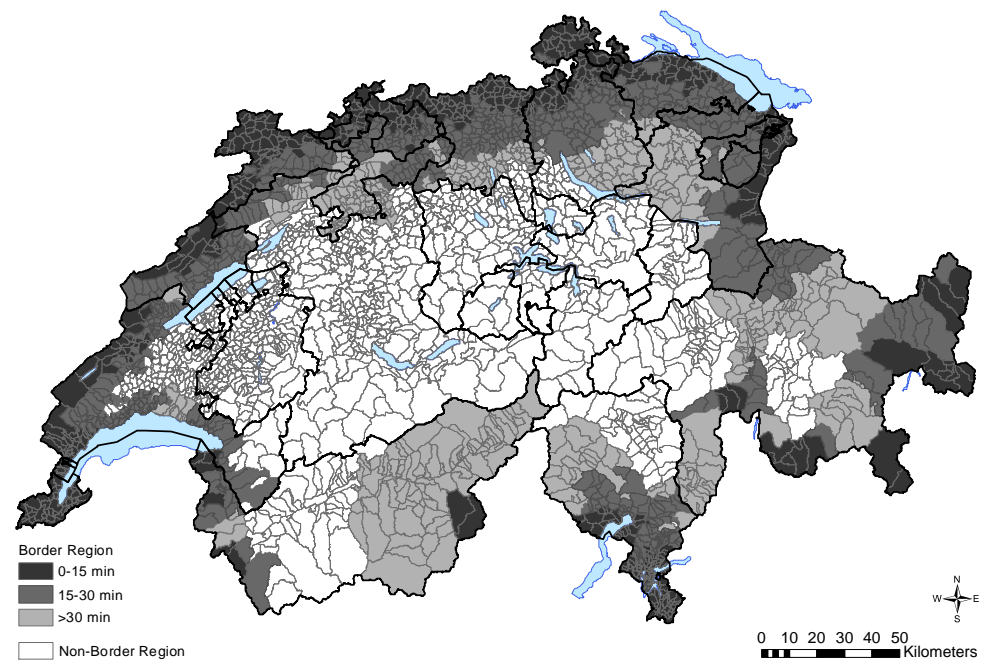

Notes: This figure depicts municipalities in the border region in three different shades of gray and those in the non-border region in white. Within the border region, we distinguish three regions according to their travel time by car to the nearest border crossing. The black lines denote cantonal borders. The border of the border region does not always overlap with cantonal borders.

The liberalizations for CBW within the BR occurred in two steps. In the transition phase that started in 1999, cantonal offices, which were responsible for handling applications for CBW, gained more discretion for doing so. Anecdotally, they exploited this to handle CBW applications in a less stringent manner. ${ }^{9}$ Several former restrictions were lifted in 2002. First, the recruitment area for CBW was expanded to the entire neighboring countries of Switzerland. Prior to 2002, Swiss firms could only hire CBW who had lived for at least six months in specific municipalities close to the border to Switzerland. Hence, the change effectively allowed workers from the interior of a neighboring country to migrate to the Swiss border to take advantage of the labor market access. Second, new cross-border permits were now generally valid for five years and no longer linked to a specific job. Before 2002, cross-border permits were formally limited to one year and ended with the

\footnotetext{
${ }^{9}$ Conversations with representatives from cantonal immigration offices revealed that there was a more relaxed handling of new CBW applications after 1999, and particularly after the national referendum on May 21, 2000, as it was clear that eventually CBW would be the first to gain unrestricted access to the BR.
} 
termination of a work contract, restricting the geographical and occupational mobility of CBW. Third, CBW were only required to commute to their place of residence weekly rather than daily. They were also granted the right to search for housing in Switzerland.

The free movement phase began in mid-2004 when firms in the BR gained full and free access to CBW. Switzerland dropped any bureaucratic admission process for CBW that had been in place before. In particular, Swiss firms had to provide evidence that they had not found, "within an appropriate period of time," resident workers who were willing and capable of filling their vacancies. This regulation called the "priority requirement" imposed a direct recruitment costs for firms hiring CBW, by requiring them to go through a relatively lengthy admission process. ${ }^{10}$ In June 2004, hiring CBW in the BR became as easy as hiring Swiss workers.

The number of CBW employed in the BR increased substantially in the years of the liberalization. Importantly, this increase in CBW was strongly concentrated in labor markets close to the border. Figure 2 uses data from the Swiss Earnings Structure Surveys to plot the share of CBW in total employment separately for the BR and the NBR. Municipalities are grouped into bins of 5 minutes travel-time by car to the nearest border crossing. The figure shows that CBW were almost exclusively employed in municipalities in the $\mathrm{BR}$ between 0 and 30 minutes from the border, both before and after the reform. The figure also reveals the change in the employment share of CBW over time. The change was very small and sometimes even negative in the pre-liberalization period (i.e. between 1994 and 1998). During the transition

\footnotetext{
${ }^{10}$ When hiring a $\mathrm{CBW}$, firms had to prepare an application detailing the job requirements of their vacancy and the working and contract conditions offered. Moreover, firms had to provide proof that they had searched unsuccessfully for a worker within Switzerland for a certain number of weeks. The application had to be sent to the cantonal and federal migration offices. The processing of the application lasted about one to three months. The migration offices evaluated each application individually, notably by comparing the job requirements with information on the qualifications of residents registered as unemployed. Today, the direct costs for Swiss firms to recruit workers from outside the EU are estimated to be about ten to twenty times larger than those for recruiting EU workers (B,S,S. Volkswirtschaftliche Beratung, 2013). This is relevant, as hiring non-EU workers is regulated similarly today as hiring $\mathrm{CBW}$ before the reform.
} 
period (1999-2003), the share increased slightly, but only in municipalities close to the border. The increase in the share is largest in the free movement phase (i.e. between 2004 and 2010), and it is larger closer to the border. It is essentially zero in municipalities that are more than 30 minutes away from the border. We also show the increase in the employment share of CBW in the NBR (panel B of Figure 2) between 2004 and 2010, but this increase is quantitatively very small.

We thus focus on firms and municipalities close to the border within the BR. Due to the limited employment of CBW in the NBR, we do not exploit the switch from no to free access for CBW in the NBR in 2007. To allow for transparent empirical analyses, we analyze the reform by partitioning Switzerland into four regions. ${ }^{11}$ Based on the evidence in Figure 2, municipalities and firms located 0-15 minutes away from the border are considered as strongly treated; those between 15 and 30 minutes as weakly treated; and firms and municipalities over 30 minutes within the BR and those in the NBR will form the two control groups NBR. Since both control areas are officially treated (one in 2004 and one in 2007), our estimates are, if anything, biased downwards if the policy had effects on regions located more than 30 minutes away from the border. In general, we present the main results using either of the two control groups because there are no strong a priori reasons to prefer one control group over the other.

Three features of the AFMP have important implications for our research design and the interpretation of our results. First, the AFMP was part of a package of seven agreements negotiated at the same time. In general, these other bilateral agreements pertained to harmonizations in specialized fields (e.g. air and land traffic, agriculture, or research cooperation) that likely had very limited effects on the outcomes that we study in this paper. ${ }^{12}$ However,

\footnotetext{
${ }^{11}$ In Beerli and Peri (2018) and Ruffner and Siegenthaler (2017), we show that the results are similar if we use finer intervals and differently defined regions, or if we exploit the continuous nature of the travel distance.

${ }^{12}$ This also holds for the agreement pertaining to research cooperation, which laid the foundation for Switzerland's full participation in the research framework programs of the
} 
Figure 2: Number of cross-border workers relative to total employment in 1998 in distance bins

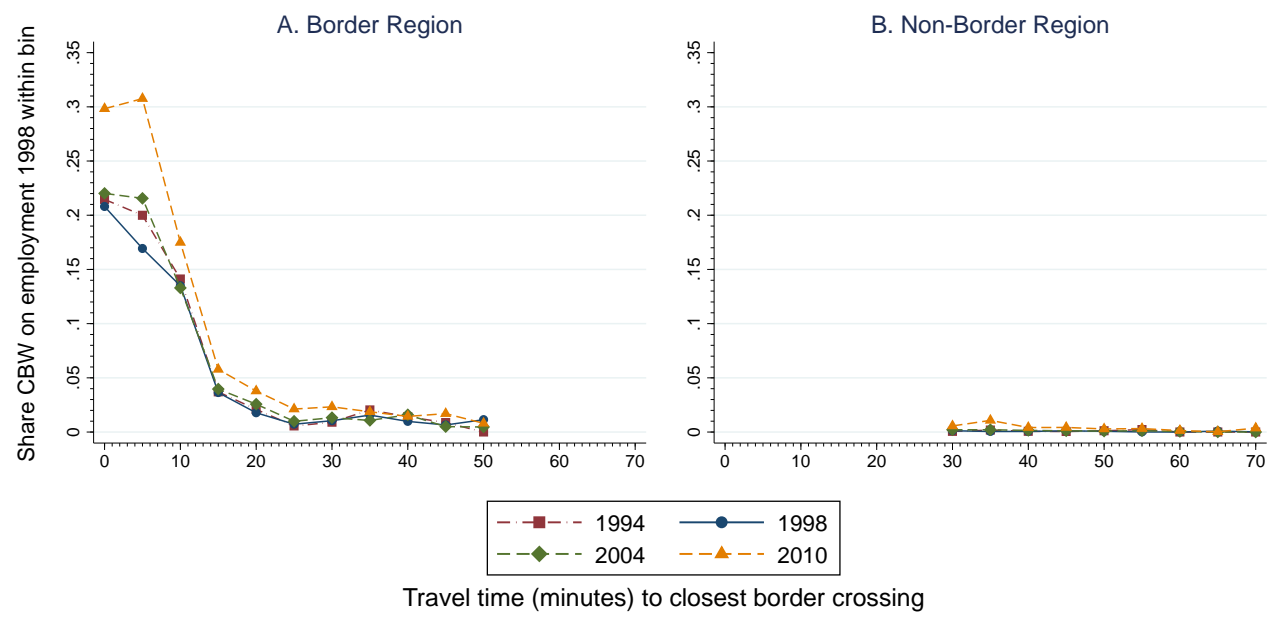

Notes: The figure plots the number of cross-border workers relative to total employment in 1994, 1998, 2004 and 2010 separately for the border region (panel A) and the non-border region (panel B). Municipalities are grouped into bins of 5 minutes according to their travel time by car to the next border crossing. Bins with very a small number of total workers are omitted, i.e. those with travel time above 50 minutes in the border region and those between 13 and 30 minutes in the non-border region. SESS data.

one agreement reduced non-tariff barriers to trade between Switzerland and the EU. It is conceivable that these trade liberalizations affected regions close to the border more than the regions further away. A central goal of our robustness checks is to demonstrate that the effects identified with our strategy are not driven by this simultaneous policy change.

Second, the AFMP also lifted all restrictions for Swiss residents to work in neighboring countries. Yet, the change in employment of CBW in Switzerland was about nine times larger than the change of CBW from Switzerland working in neighboring countries. This reflects the much higher nominal wages and cost of living in Switzerland that make it very unattractive to live in Switzerland while working abroad. ${ }^{13}$ Our analyses thus abstract from the

EU. The programs are targeted to scientific institutions. Moreover, the agreement merely formalized Switzerland's former affiliation within the program, and thus had limited impact on research contributions to Swiss institutions. The impacts of the agreement on private-sector innovation outcomes in our sample period are thus likely very limited.

${ }^{13}$ See Table A.2 in the appendix. Data from the Eurostat/OECD purchasing power parities (PPP) program suggest that consumer prices were between 23\% (France) to $34 \%$ (Germany) lower in neighboring countries compared with Switzerland in 2009. Eurostat's labor cost survey in 2012 suggests that nominal wage costs per hour are between $33 \%$ (France) to $46 \%$ (Italy) lower in neighboring countries. 
fact that the reform lifted restrictions on Swiss CBW.

Third, we interpret the reform as increasing the availability of $C B W$ in regions close to the border. This is not equivalent to interpreting the reform as an increase in the supply of CBW. The reform also plausibly affected the CBW already working in Switzerland prior to the reform, as these CBW enjoyed increased geographical and occupational mobility. Moreover, as any reform that reduces restrictions on labor mobility, the reform plausibly increased the ease with which firms could find skilled workers and reduced the probability that firms perceived to be limited by labor market regulation in hiring foreign workers, as shown below. Therefore, the reform likely had a direct impact on firms' incentives to create jobs (see section 6). Another implication is that we focus on the reduced-form effects of the reform throughout - the extent to which permanently opening the labor market for CBW affected resident workers and firms - and abstain from presenting IV estimates that scale the reduced-form effects with the effect on the employment share of CBW. Such IV estimates would entail an interpretation of the coefficients as impact of labor supply changes.

\section{Data and empirical strategy}

\subsection{Data}

Our empirical analyses are based on three data sets (Table A.1 in the appendix provides an overview). The main data sources for the labor market analysis are the Swiss Earnings Structure Surveys (SESS). The Swiss Federal Statistical Office (FSO) has conducted these surveys every two years since 1994. They are a stratified random sample of private and public firms with at least three full-time equivalent (FTE) workers from the manufacturing and service sectors, covering between 16.6\% (1996) and 50\% (2010) of total employment in Switzerland. The data include detailed information about workers, their wages and full-time equivalents, their demographic characteristics, and their place of work. We focus on individuals aged 18-65, 
working in the private sector, with non-missing information for nationality, place of work, education, wages, full-time equivalents, and some other basic demographics. ${ }^{14}$ Based on information about workers' residency permits, we distinguish between native workers - those with Swiss nationality either born in Switzerland or naturalized-, foreign-born workers with a residency permit which we call resident immigrants $I$, and CBW. Using the SSES, we analyze the reform effects on the number of cross-border and foreignborn workers as a share of total employment, and the effects on full-time equivalents and real hourly wages of natives. We define workers with tertiary education as being highly educated. Workers with completed secondary education (such an apprenticeship) and those with primary education are combined in a group of lower educated. ${ }^{15}$

Our second data source consist of seven waves of the Swiss Business Censuses (BC) conducted in 1991, 1995, 1998, 2001, 2005, 2008, and 2011 by the FSO in October. The BC constitute a panel dataset covering the universe of private and public establishments in Switzerland. Approximately 4 million employed persons in 389,000 workplaces are included in the census of 2008 . The data provide us with information on the size (FTE employment) and the exact geographical location (geographic coordinates) of all establishments in Switzerland. Until 2008, the censuses were based on mandatory surveys. In 2011, the census was constructed from register data.

The third data source is the innovation surveys (IS) of the KOF Swiss Economic Institute. These surveys were conducted among Swiss companies between 1996 and 2013 in seven waves. All surveys are based on a representative sample of private-sector firms with at least five FTE employees. The surveys are stratified with respect to firm size and two-digit industry

\footnotetext{
${ }^{14}$ Appendix B.1 contains a detailed discussion of the sample construction for the labor market analysis.

${ }^{15}$ There are some a priori reasons to show separate results for these two subgroups. This is the approach followed in Beerli and Peri (2018). For brevity and because of the similarity of the labor market results, we decided to pool the two subgroups in this version. Indeed, previous research suggests that these two subgroups are closely substitutable (Gerfin and Kaiser, 2010; Müller and Graf, 2015).
} 
affiliation. The IS provide very detailed information on the characteristics of the surveyed firms and a rich set of outcomes such as value added and the number of patent applications filed. However, the data cover only a relatively small sample of firms per wave, and have the some of the limitations of voluntary surveys such as reporting errors, attrition and non-response. The average response rate across all surveys is $35 \%$. In addition, the unit of observation is the firm, not the establishment. We thus have to assign multi-establishment firms to the location of the headquarter. ${ }^{16}$ As a result, our estimates with the IS are not very precise.

\subsection{Descriptive statistics}

Panel A of Table 2 compares the pre-reform characteristics of workers and firms of the four regions that we compare in our DiD estimations: highlytreated regions and weakly treated regions (within 15 and 15-30 minutes to the border in the BR, respectively), and the two control regions (in the BR with more than 30 minutes to the border and the NBR). The table suggests that the four groups are quite comparable in terms of labor market size, important worker characteristics, and workers' mean log hourly wages. While the employment of CBW was much larger in the treated regions before the reform, the employment share of resident immigrants was similar. The panel also suggests that neither of the two control groups is clearly more comparable to the highly treated region. Similar comments apply if we compare the characteristics of establishments (BC) and firms (IS) across regions (Panels $\mathrm{B}$ and $\mathrm{C}$ of Table 2). However, we also observe some important differences such as the fact that highly treated establishments are somewhat larger and more likely to be exporters than establishments in the two control groups.

In the appendix, we also describe the characteristics of the CBW working in the BR after 1998. Three features are noteworthy (see Table A.3). First, while CBW were on average less educated than natives before the reform,

\footnotetext{
${ }^{16}$ Appendix B.2 provides detailed discussions on how we constructed our estimation sample for the two datasets and how we assign firms to BR and NBR.
} 
Table 2: Firm and worker characteristics prior to the reform, by region

\begin{tabular}{|c|c|c|c|c|c|c|c|c|}
\hline \multirow{3}{*}{ Travel time to border } & \multicolumn{6}{|c|}{ Border region } & \multirow{2}{*}{\multicolumn{2}{|c|}{$\begin{array}{c}\text { Non-border } \\
\text { region }\end{array}$}} \\
\hline & \multicolumn{2}{|c|}{$\leq 15 \mathrm{~min}$} & \multicolumn{2}{|c|}{$15-30 \mathrm{~min}$} & \multicolumn{2}{|c|}{$>30 \mathrm{~min}$} & & \\
\hline & mean & sd & mean & sd & mean & sd & mean & sd \\
\hline \multicolumn{9}{|l|}{ A. Demographics (SESS) } \\
\hline Share highly educated & 0.18 & $(0.38)$ & 0.19 & $(0.39)$ & 0.16 & $(0.37)$ & 0.15 & $(0.36)$ \\
\hline Share lower educated & 0.82 & $(0.38)$ & 0.81 & $(0.39)$ & 0.84 & $(0.37)$ & 0.85 & $(0.36)$ \\
\hline Mean age & 39.62 & $(10.92)$ & 39.37 & $(11.30)$ & 39.11 & $(11.28)$ & 38.74 & $(11.41)$ \\
\hline Share male & 0.61 & $(0.49)$ & 0.63 & $(0.48)$ & 0.61 & $(0.49)$ & 0.61 & $(0.49)$ \\
\hline Mean tenure (in years) & 8.88 & $(8.56)$ & 8.37 & $(8.57)$ & 8.51 & $(8.59)$ & 8.63 & $(8.61)$ \\
\hline Mean log hourly wage & 3.50 & $(0.38)$ & 3.55 & $(0.37)$ & 3.46 & $(0.35)$ & 3.45 & $(0.35)$ \\
\hline Share cross-border workers & 0.18 & $(0.38)$ & 0.02 & $(0.13)$ & 0.01 & $(0.10)$ & 0.00 & $(0.02)$ \\
\hline Share resident immigrants & 0.06 & $(0.23)$ & 0.05 & $(0.22)$ & 0.07 & $(0.25)$ & 0.05 & $(0.23)$ \\
\hline No. of workers & 501,660 & & 674,040 & & 287,722 & & 495,095 & \\
\hline \multicolumn{9}{|l|}{ B. Establishments $(B C)$} \\
\hline Travel minutes to border & 7.05 & $(3.54)$ & 23.36 & $(4.07)$ & 39.95 & $(10.79)$ & 54.06 & $(13.98)$ \\
\hline Mean FTE employment & 17.84 & $(67.57)$ & 18.13 & $(60.60)$ & 15.16 & $(51.33)$ & 14.76 & $(47.58)$ \\
\hline Share exporter (1995) & 0.20 & $(0.40)$ & 0.18 & $(0.38)$ & 0.15 & $(0.36)$ & 0.13 & $(0.33)$ \\
\hline Share importer (1995) & 0.30 & $(0.46)$ & 0.29 & $(0.45)$ & 0.24 & $(0.43)$ & 0.23 & $(0.42)$ \\
\hline Share in high-tech manufacturing & 0.05 & $(0.21)$ & 0.04 & $(0.20)$ & 0.05 & $(0.21)$ & 0.04 & $(0.20)$ \\
\hline Share in low-tech manufacturing & 0.12 & $(0.32)$ & 0.11 & $(0.32)$ & 0.12 & $(0.32)$ & 0.13 & $(0.34)$ \\
\hline Share in knowl.-intensive services & 0.24 & $(0.43)$ & 0.25 & $(0.44)$ & 0.23 & $(0.42)$ & 0.21 & $(0.41)$ \\
\hline Share in not-knowl.-intensive services & 0.47 & $(0.50)$ & 0.46 & $(0.50)$ & 0.46 & $(0.50)$ & 0.47 & $(0.50)$ \\
\hline Observations & 17,234 & & 22,996 & & 11,086 & & 23,646 & \\
\hline \multicolumn{9}{|l|}{ C. Firms (IS) } \\
\hline Firm age (years) & 45.28 & $(35.30)$ & 45.44 & $(37.88)$ & 46.08 & $(36.21)$ & 51.37 & $(48.62)$ \\
\hline Firms with R\&D expenditures & 0.43 & $(0.50)$ & 0.51 & $(0.50)$ & 0.49 & $(0.50)$ & 0.42 & $(0.49)$ \\
\hline Export share in sales & 0.22 & $(0.33)$ & 0.21 & $(0.32)$ & 0.20 & $(0.31)$ & 0.17 & $(0.30)$ \\
\hline Share academics in workforce & 0.18 & $(0.22)$ & 0.19 & $(0.21)$ & 0.16 & $(0.18)$ & 0.15 & $(0.17)$ \\
\hline Total sales $(\ln )$ & 16.15 & $(1.84)$ & 16.50 & $(1.87)$ & 16.13 & $(1.84)$ & 16.11 & $(1.77)$ \\
\hline Wage per FTE worker (ln) & 11.12 & $(0.52)$ & 11.21 & $(0.53)$ & 11.13 & $(0.48)$ & 11.13 & $(0.47)$ \\
\hline Value added per FTE worker (ln) & 11.69 & $(0.56)$ & 11.82 & $(0.63)$ & 11.74 & $(0.52)$ & 11.73 & $(0.55)$ \\
\hline High skill shortage & 0.17 & $(0.37)$ & 0.18 & $(0.38)$ & 0.19 & $(0.39)$ & 0.17 & $(0.38)$ \\
\hline High R\&D shortage & 0.17 & $(0.38)$ & 0.17 & $(0.37)$ & 0.17 & $(0.37)$ & 0.15 & $(0.36)$ \\
\hline Observations & 932 & & 1428 & & 610 & & 1117 & \\
\hline
\end{tabular}

Notes: The table shows descriptive statistics in the border and non-border region. The border region is split into three groups depending on the travel duration to the nearest border crossing. Panel A shows average worker characteristics for the sample of all workers aged 18-64 employed in the private sector from the Swiss Earnings Structure Survey (SESS). Panel B shows establishments characteristics from the Business Census (BC) in 1998 (or 1995, if indicated). Panel C shows average firm characteristics using data from the KOF innovation surveys 1996 and 1999, focusing on characteristics unavailable in the BC. In this panel, entries represent averages per region of all firm-year observations in the two surveys.

we observe a large increase in the share of highly educated CBW in the 1998-2010 period (+12.6\%). Consistent with such high education levels, the employment of CBW grew most in occupations with high and intermediate wage levels. ${ }^{17}$ Second, the increase in CBW was largest in IT, R\&D, business services, real estate and, to a lesser extent, in the health sector, suggesting that many new CBW and resident immigrants were professionals in science and technology. Third, using a Mincer regression, we find that wages of CBW are similar to those of natives, after controlling for observable characteristics, suggesting that CBW have comparable labor market skills as observationally similar natives.

\footnotetext{
${ }^{17}$ Beerli et al. (2017) show that the increase in tertiary education among new immigrants in Switzerland between 1990-2010 was a response to long-term, technology-driven increase in the demand for skills.
} 


\subsection{Empirical specification and identification}

Our basic empirical specification estimates the effects of the greater availability of CBW on Swiss firms and workers by exploiting that the reform interacted with the proximity to the border. We differentiate the effects of the transition and the free movement phase of the reform by defining the dummies Transition $_{t}$ and Free $_{t}$ that are equal to one in the years $1999 \leq t<2004$ and $t \geq 2004$, respectively, and zero otherwise. We interact these reform variables with two indicators, $I\left(d_{i} \leq 15\right)$ and $I\left(15<d_{i} \leq 30\right)$, which are equal to one if unit $i$ is located within 15 minutes or at 15 to 30 minutes travel time $d_{i}$ to the nearest border crossing. ${ }^{18}$ Using these variables, we estimate the following DiD model for an outcome $y_{i, t}$ relative to unit $i$ (a municipality, an establishment, or a firm) in year $t$ :

$$
\begin{aligned}
y_{i, t}= & \beta_{d 1}^{T}\left[\text { Transition }_{t} \times I\left(d_{i} \leq 15\right)\right]+\beta_{d 2}^{T}\left[\text { Transition }_{t} \times I\left(15<d_{i} \leq 30\right)\right] \\
& +\beta_{d 1}^{F}\left[\text { Free }_{t} \times I\left(d_{i} \leq 15\right)\right]+\beta_{d 2}^{F}\left[\text { Free }_{t} \times I\left(15<d_{i} \leq 30\right)\right] \\
& +\alpha_{i}+\alpha_{t}+\gamma \text { Controls }_{i, t}+\epsilon_{i, t}
\end{aligned}
$$

In this model, $\beta_{d 1}^{\text {phase }}$ and $\beta_{d 2}^{\text {phase }}$ capture the impact of a specific phase of the reform on highly and lightly treated units, respectively, i.e. the differential evolution in the outcome $y_{i, t}$ in these groups during the transition phase and free movement phase relative to the control group. We use two different control groups: units in the BR located more than 30 minutes from the border and units in the NBR. ${ }^{19}$ The term $\alpha_{t}$ represents year fixed effects,

\footnotetext{
${ }^{18}$ The travel distance to the border is computed using information on the location of establishments (BC) and firms (IS). $d_{i}$ is time-invariant because a time varying measure could be endogenous (e.g. represent a relocation of firms in response to the commuting scheme). In the firm regressions, we assign firms to their location in 1998 throughout the estimation period. For the municipality-level specifications, we use the BC 1995 and 1998 to compute the employment-weighted average travel time to the border of the establishments in a municipality. See section B.2 in the appendix for further details.

${ }^{19}$ If we use the NBR as the control group, we exclude the very few establishments and municipalities located in the NBR within less than 30 minutes to the border. The reason is that these units may be affected by the switch from no to free access to CBW that occurred in 2007 (see Table 1).
} 
which absorb the time variation common to all units such as common changes in aggregate prices and demand and the dummies Transition and Free $_{t} . \alpha_{i}$ represent unit fixed effects that control for pre-existing differences between regions. Such differences could have been a direct consequence of the longestablished cross-border policy that restricted the hiring of CBW to the BR.

The central identifying assumption of our approach is that we would have observed a common average change in outcomes within units, conditional on controls, in the three regions absent the reform. We will test the plausibility of this assumption in several ways. Most importantly, we check how the outcomes in the three relevant regions evolved before the reform. To this end, we generalize equation (1) to an event study model. In the case of the data from the SESS, the model takes the following form:

$$
\begin{aligned}
y_{i, t}= & \alpha_{i}+\alpha_{t}+\sum_{t=1994}^{2010} \gamma_{d 1, t} I(\text { year }=t) \times\left[I\left(d_{i} \leq 15\right)\right] \\
& +\sum_{t=1994}^{2010} \gamma_{d 2, t} I(\text { year }=t) \times\left[I\left(15<d_{i} \leq 30\right)\right]+\text { SControl }_{i, t}+\epsilon_{i, t}
\end{aligned}
$$

The estimates of the coefficients $\gamma_{d 1, t}$ for $t \geq 1999$ reveal the reform effects on the highly treated units. $\gamma_{d 2, t}$ reveal the effects on lightly treated units. As the impact of the policy should be zero before its announcement, we should find that $\gamma_{d 1 t}=\gamma_{d 2, t}=0$, for $t<1998$. We standardize the effects to 0 in 1998 by dropping the indicator for that year from the regression.

Arguably, the main threat to a causal interpretation of our estimates is unobserved factors that are correlated with the timing of the reform and that affect regions differently depending on the distance to the border. Candidate confounding factors are simultaneous other reforms (e.g. due to changes in cantonal policies) and unobserved region-specific shocks to prices, demand, or productivity. We partially account for such factors by including linear time trends for each NUTS-II region in our vector of control variables, Controls $s_{i, t}$. In sections 5.2 and 7.5, we also provide several checks 
that suggest that our results are not confounded by unobserved region- or industry-specific shocks and by the simultaneous changes in trade policies.

Another remark concerns inference. We cluster standard errors at the level of commuting zones (CZ), both in the municipality- and firm-level regressions. We thus allow for arbitrary dependence, cross-sectional and over time, between units within the same CZ. In tables A.8 and A.15, we compare the standard errors based on this strategy with standard errors clustered at the unit (firm/municipality), two-digit industry, and cantonal level, and with standard errors based on the Spatial Heteroskedasticity and Autocorrelation Consistent (SHAC) variance estimator proposed by Conley (1999), also used by Dustmann et al. (2017). This estimator allows for correlation between areas that are geographically close but belong to different regional units. These alternative standard errors are often substantially smaller than our preferred ones. Our inference is thus conservative.

\section{Effects of the policy on immigration}

Our empirical strategy depends on the idea that the immigration reform affected regions close to the border more. Figure 2 provides descriptive evidence that supports this idea. Using the SESS from 1994 to 2010, we now analyze the exact dynamics of the change in total immigrant exposure in municipalities located close to the Swiss border compared to those farther away. Panel A of Figure 3 plots the coefficients $\gamma_{d 1, t}$ and $\gamma_{d 2, t}$ and their $95 \%$ confidence intervals in a regression as specified in equation (2) when either the BR $30+$ or the NBR constitutes the control group. The dependent variable is the number of total immigrant workers (CBW plus resident immigrants) in municipality $i$ and year $t$ standardized by total employment in $1998, \frac{C B W_{i, t}+I_{i, t}}{E m p_{i, 1998}} .^{20}$

Panel A reveals several important features in the evolution of immigrant

\footnotetext{
${ }^{20}$ We standardize the number of immigrants by total local employment (native and foreign workers) in the last year prior to the reform, 1998, rather than contemporaneous total employment, as immigration may affect contemporaneous total employment (Dustmann et al., 2017).
} 
Figure 3: Effect of free movement policy on the number of CBW and resident immigrants
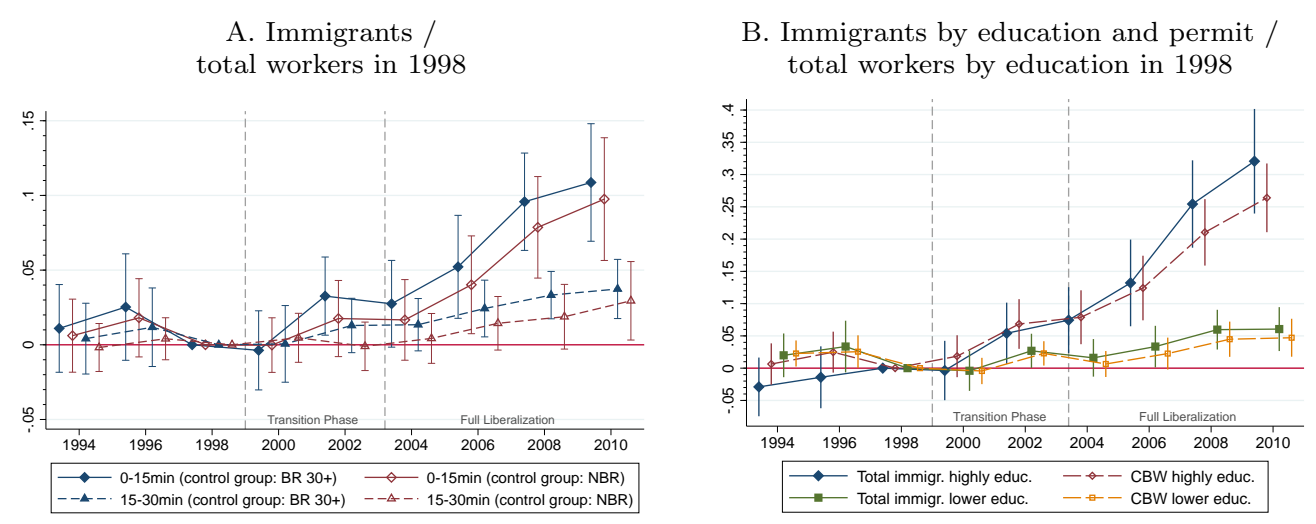

Notes: The figure shows the effect of the free movement policy on immigration. It plots the estimated reform effects and associated 95\% confidence intervals for highly treated municipalities (Panel A: and weakly treated municipalities) based on the event study model (equation (2)). In Panel A, the dependent variable is the number of immigrants relative to total employment in 1998. We present separate estimates for the two control groups (BR 30+ and NBR). In Panel B, the dependent variable is the number of highly or lower educated immigrants (or CBW only) relative to the total number of workers in the same group in 1998. In this panel, the control group is the BR 30+. Regressions are weighted using the total workforce in 1998 in a cell. All regressions account for municipality and period fixed effects, and linear trends per NUTS-II region. Standard errors are clustered on the CZ level. SESS data.

exposure by region. First, in the pre-1999 period, none of the estimates for any of the interactions is significantly different from zero at the $95 \%$ confidence level. There are thus no differences in the trends of the number of immigrants between municipalities close to the border and either control group before the reform. Second, there is a mild upward trend in the number of immigrants as a share of 1998 employment between 2000 and 2002 in highly treated municipalities. The estimated increase is between 1.5 and 3 percentage points in 2002 depending on the control group, suggesting a small reform effect on immigrant employment in the highly treated regions during the transition phase. Third and most importantly, the number of immigrants as a share of 1998 employment grows consistently in highly treated municipalities after 2004, and to a lesser extent in weakly treated municipalities. By 2010, the reform led to an increase in the share by about 10 percentage points in the highly treated regions. As expected, the estimates indicate that the reform effect was smaller-about a third-in the weakly treated regions. Fourth, the estimates based on the NBR control group are slightly lower but not statistically different from those based on the BR $30+$ con- 
trol. If we compare the average outcome in the free movement period with the entire pre-reform period, as we do in our baseline DiD model (equation (1)), we estimate an increase in the number of immigrants as a share of 1998 employment by 5.6 (using the BR 30+ as control) and 3.7 (using the NBR) percentage points, respectively (see columns 1 and 2 of Table 3 ).

The regressions in columns 3-6 of Table 3 show how different immigrant subgroups contributed to this aggregate inflow of immigrants. Columns 3 and 4 of Table 3 show that two-thirds (3.8 of 5.6 percentage points) of the total increase in immigrants in the free movement phase in highly treated regions can be attributed to inflows of CBW. In turn, part of the excess increase in the highly treated regions is attributable to resident immigrants, $I_{i, t}$. Considering the legal circumstances and the fact that the pre-reform share of resident immigrants was similar in the relevant regions (see panel A of Table 2), we would expect that the liberalizations for resident immigrants affected treated and control regions similarly. We thus interpret these findings as evidence that the greater availability of CBW attracted (crowded in) resident immigrants - an effect that is statistically significant, as shown in column 4 of Table 3 . This interpretation is consistent with the timing of the effect on resident immigrants, which follows the surge in CBW. ${ }^{21}$

Columns 5 and 6 of Table 3 show that most of the increase in CBW is attributable to inflows of highly educated CBW (3.8 of 5.6 percentage points). Indeed, Panel B of Figure 3 shows that the inflow of highly educated immigrants was very substantial relative to the pre-existing pool of highly educated native workers in 1998: by 2010, the policy increased the number of highly educated immigrants as a share of total employment of highly educated workers in 1998 by roughly 30 percentage points in the highly treated region. In contrast, the growth of immigrants within the group of lower educated workers was much lower (6 percentage points). Complementing this

\footnotetext{
${ }^{21}$ The excess increase in the number of resident immigrants close the borderillustrated in Panel B of Figure 3 by the divergence in the effects on total immigrants and CBW - starts in 2006 and thus 2-4 years after the start of the increase in the number of CBW.
} 
picture, Table A.4 shows that the largest contribution to the overall growth in the number of immigrants came from occupations with high pay, such as R\&D workers, IT specialists, analysts and consultants, and to a lesser extent from those with middle pay.

Table 3: Effect of free movement policy on the number of immigrants by permit type and educational attainment

\begin{tabular}{|c|c|c|c|c|c|c|}
\hline & \multicolumn{4}{|c|}{ Immigrants by permit type } & \multicolumn{2}{|c|}{$\begin{array}{l}\text { Total immigrants } \\
\text { by education group }\end{array}$} \\
\hline & \multicolumn{2}{|c|}{ All } & \multirow{2}{*}{$\begin{array}{c}\text { CBW } \\
(3) \\
\end{array}$} & \multirow{2}{*}{$\frac{\text { Residents }}{(4)}$} & \multirow{2}{*}{$\begin{array}{c}\text { High } \\
(5) \\
\end{array}$} & \multirow{2}{*}{$\frac{\text { Lower }}{(6)}$} \\
\hline & $(1)$ & $(2)$ & & & & \\
\hline Transition $_{t} \cdot I\left(d_{i} \leq 15\right)$ & $\begin{array}{c}0.001 \\
(0.008)\end{array}$ & $\begin{array}{l}-0.005 \\
(0.009)\end{array}$ & $\begin{array}{l}-0.001 \\
(0.008)\end{array}$ & $\begin{array}{c}0.002 \\
(0.007)\end{array}$ & $\begin{array}{c}0.007^{* * *} \\
(0.003)\end{array}$ & $\begin{array}{l}-0.006 \\
(0.007)\end{array}$ \\
\hline Transition $_{t} \cdot I\left(15<d_{i} \leq 30\right)$ & $\begin{array}{c}0.002 \\
(0.008)\end{array}$ & $\begin{array}{l}-0.003 \\
(0.008)\end{array}$ & $\begin{array}{c}0.002 \\
(0.004)\end{array}$ & $\begin{array}{l}-0.001 \\
(0.007)\end{array}$ & $\begin{array}{l}0.004^{*} \\
(0.002)\end{array}$ & $\begin{array}{l}-0.002 \\
(0.007)\end{array}$ \\
\hline Free $_{t} \cdot I\left(d_{i} \leq 15\right)$ & $\begin{array}{c}0.056^{* * *} \\
(0.014)\end{array}$ & $\begin{array}{c}0.037^{* *} \\
(0.014)\end{array}$ & $\begin{array}{c}0.038^{* * *} \\
(0.013)\end{array}$ & $\begin{array}{r}0.018^{* *} \\
(0.008)\end{array}$ & $\begin{array}{c}0.038^{* * *} \\
(0.007)\end{array}$ & $\begin{array}{c}0.018^{* *} \\
(0.009)\end{array}$ \\
\hline Freet $_{t} \cdot I\left(15<d_{i} \leq 30\right)$ & $\begin{array}{c}0.022^{* * *} \\
(0.008)\end{array}$ & $\begin{array}{c}0.007 \\
(0.010)\end{array}$ & $\begin{array}{r}0.011^{* *} \\
(0.005)\end{array}$ & $\begin{array}{l}0.012^{*} \\
(0.007)\end{array}$ & $\begin{array}{c}0.011^{* * *} \\
(0.004)\end{array}$ & $\begin{array}{l}0.012^{*} \\
(0.006)\end{array}$ \\
\hline R-squarec & 0.517 & 0.516 & 0.545 & 0.332 & 0.548 & 0.464 \\
\hline Observations & 9585 & 12051 & 9585 & 9585 & 9585 & 9585 \\
\hline \# Clusters & 72 & 95 & 72 & 72 & 72 & 72 \\
\hline $\begin{array}{l}\text { Control group: BR } 30+ \\
\text { Control group: NBR }\end{array}$ & $\sqrt{ }$ & $\sqrt{ }$ & $\sqrt{ }$ & $\sqrt{ }$ & $\sqrt{ }$ & $\sqrt{ }$ \\
\hline $\begin{array}{l}\text { Year/Area fixed effects } \\
\text { Nuts-II trends }\end{array}$ & $\begin{array}{l}\sqrt{ } \\
\sqrt{ }\end{array}$ & $\begin{array}{l}\sqrt{ } \\
\sqrt{ }\end{array}$ & $\begin{array}{l}\sqrt{ } \\
\sqrt{ }\end{array}$ & $\begin{array}{l}\sqrt{ } \\
\sqrt{ }\end{array}$ & $\begin{array}{l}\sqrt{ } \\
\sqrt{ }\end{array}$ & $\begin{array}{l}\sqrt{ } \\
\sqrt{ }\end{array}$ \\
\hline \multicolumn{7}{|c|}{$\begin{array}{l}\text { Notes: The table shows the effect of the free movement policy on the number of immigrants based on } \\
\text { equation (1). In columns } 1 \text { and } 2 \text {, the dependent variable is the number of immigrants standardized } \\
\text { with total employment in } 1998 \text {. In columns } 3 \text { and } 4 \text {, the dependent variable is the number of CBW or } \\
\text { resident immigrants, respectively, standardized with total employment in } 1998 \text {. In column } 5 \text { and } 6 \text {, the } \\
\text { dependent variable is the total number highly or lower educated immigrants, respectively, standardized } \\
\text { by total employment in } 1998 \text {. Transition } t \text { is one for the period between } 2000 \text { and } 2003 \text {, whereas Freet } \\
\text { is one from year } 2004 \text { onward. }\left(d_{i} \leq x\right) \text { and }\left(y<d_{i} \leq z\right) \text { indicate whether a municipality is located } \\
\text { less than } x \text { travel minutes or between } y \text { and } z \text { travel minutes from the next border crossing, respectively. } \\
\text { Regressions are weighted using the total workforce in } 1998 \text { in a cell. Robust standard errors, clustered by } \\
\text { commuting zone, are shown in parentheses. }{ }^{* * *},{ }^{* *},{ }^{*} \text {, denote statistical significance at the } 1 \%, 5 \% \text { and } \\
10 \% \text { level, respectively. SESS data. }\end{array}$} \\
\hline
\end{tabular}

In sum, the free movement policy increased the supply of CBW and of other resident immigrants by about 10 percentage points by 2010 in municipalities within 0-15 minutes from the border. Two thirds of the new CBW were highly educated. As expected, the increase in immigrants' supply was smaller 15-30 minutes from the border and was most pronounced after 2004, when the labor market in the BR was fully opened to CBW. 


\section{$5 \quad$ Labor market effects}

\subsection{Main results}

In this section, we investigate whether the greater availability of (mainly highly educated) CBW depressed wages or employment opportunities of (highly educated) natives. We analyze wage and employment outcomes of natives jointly as they represent different margins of adjustment to the shock, potentially heterogeneous across groups due to group-specific labor supply elasticities or wage rigidities (see Dustmann et al., 2016, for a discussion).

Part I of Figure 4 provides evidence on the wage and employment effects of the free movement policy on natives. It plots the event study estimates (equation 2) for the highly treated regions (0-15 minutes) using average log real hourly native wages (panel A) and log total native workers (panel B) as dependent variables, respectively. We present the results using both control groups separately. Table A.5 in the appendix presents the corresponding point estimates from our baseline DiD model (equation 1).

Panels A and B of Figure 4 show that natives' wages and employment evolved similarly in the treatment group and in both control groups prior to 1999. This remains true in the reform period: the estimated reform effects are never significant for both outcomes. In terms of employment of native workers, the point estimates are close to zero based on the BR $30+$ control group and slightly negative but non-significant based on the NBR control group. Hence, we neither find statistically significant evidence of a negative effect on average native wages nor a clear effect on native employment despite the substantial increase in immigrant employment in highly treated regions. Our establishment-level regressions based on data from the business censuses presented below strengthen this view: we find no evidence that the substantial increase in employment of foreigners reduced FTE employment of Swiss nationals within establishments (see Figure 5).

In panels $\mathrm{C}$ and $\mathrm{D}$ of Figure 4, we look at the impacts on highly and lower educated native workers separately. The estimates represent the "to- 
Figure 4: Effect of free movement policy on wages and employment of natives

I. Aggregate effects

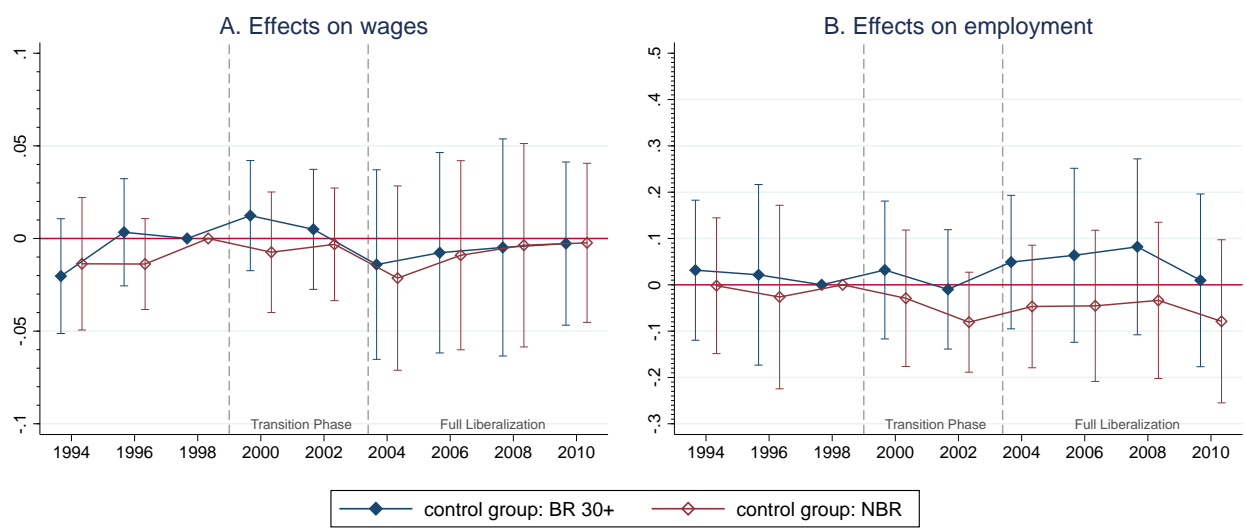

II. Effects by education group
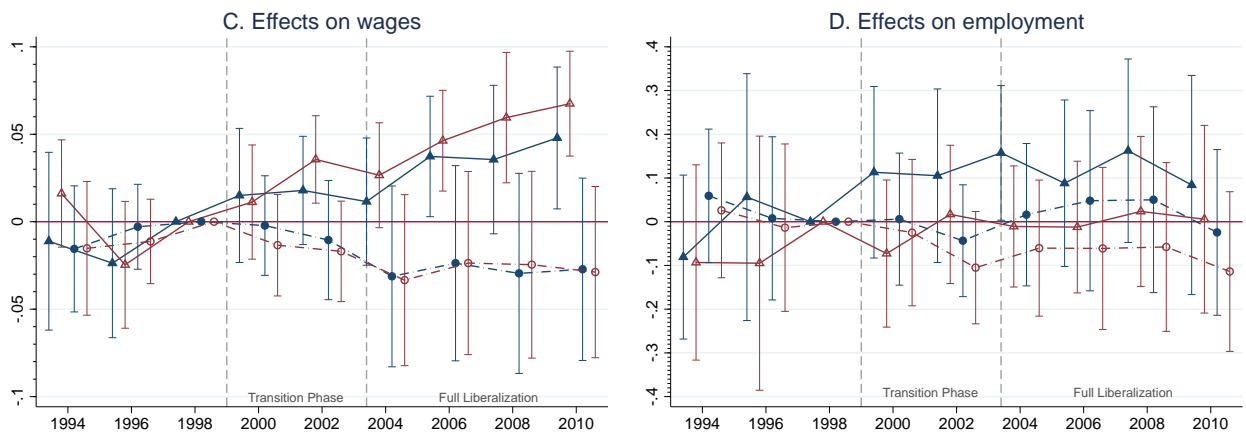



Notes: The figure shows the effects of the free movement policy on real wages and employment of native workers. It plots the event study coefficients and associated 95\% confidence intervals for the highly treated municipalities based on equation (2). The dependent variables are natives' average log hourly real wage (panel A and C) and log total workers (panel B and D) per education group. We present separate estimates for the two control groups (BR 30+ and NBR). The regressions are weighted using the number of natives in a cell. Control variables are municipality and year fixed effects and linear NUTS-II trends. Standard errors are clustered by commuting zone. SESS data.

tal" effect of immigrants on wages and employment of each education group

of natives. They capture the impact on natives both from competition with immigrants with similar skills and from complementarity to those with different skills. ${ }^{22}$ As the free movement policy produced a larger inflow of CBW with tertiary education relative to those with lower qualifications, the canonical "partial effects" model would imply downward pressure on wages and employment of highly educated natives and possibly positive effects on

\footnotetext{
${ }^{22}$ See Ottaviano and Peri (2012) for a more formal argument about the estimation of a total effect of immigrants aggregating all the direct competition and indirect complementarity effects from different skill groups.
} 
lower-educated natives through complementarity.

This is not what we find. Rather, panel $\mathrm{C}$ of Figure 4 suggests a positive effect on real wages of highly educated natives that starts in the transition phase and grows to $+4.5 \%$ in the free movement period. This positive wage effect is evident using either control group (cf. panels A and B of Table A.5), it is robust, and economically significant: real wages of highly educated natives grew by only 3\%, on average, in the BR between 1998 and 2010. The effects on employment for highly educated workers are imprecisely estimated but rule out strong negative employment effects. If anything, they are consistent with increased employment of highly educated native workers. On the other side, we find negative point estimates on some of the outcomes of low educated natives. None of the estimates, however, is consistently statistically significant, and we cannot rule out zero effects on this group. Nevertheless, these heterogeneous point estimates by education group explain why we find a zero effect in the aggregate that averages those effects.

Overall, we find that highly educated natives gained from the increased availability of mostly highly educated CBW. This evidence is difficult to explain in a competitive labor market framework where immigration represents an increase in labor supply with a fixed labor demand. We develop this point below.

\subsection{Robustness of labor market results}

First, however, we discuss a series of important robustness checks for these labor market results. As in every DiD estimation, it is a first-order concern that the effects may be caused by a failure of common trends in outcomes across regions or by unobserved confounders. Potential confounders are changes in regional policies, unobserved demand, and productivity shocks that have a regionally unequal impact e.g. due to differences in the industrial composition of regions. We address these concerns in several ways. In panel B of Table A.6, we show that the estimated labor market effects are very close to the baseline estimates across the different outcomes if we include a 
Bartik (1991) variable, which controls for region-specific, sector-driven demand trends or shocks. ${ }^{23}$ Similarly, the results are similar when we control for unobserved region-specific shocks using NUTS-II regions times year fixed effects (panel C of Table A.6), if we exclude the linear time trends contained in our baseline regression model (Panel D of Table A.6), and if we drop the most important large cities one by one (Table A.7). ${ }^{24}$ In section 7.5, we also present several pieces of evidence suggesting that our results are indeed attributable to increased labor mobility rather than caused by one of the other bilateral agreements which were signed at the same time.

Another concern with our labor market results is that they are driven by effects on the composition of native workers rather than by effects on "incumbent" workers in the regions of interest. The main concern in our case differs from the concern about native outflows in the existing literature, i.e. the fact that native workers may respond to immigrant inflows by leaving the labor market or the region (Borjas, 2006; Dustmann et al., 2017). Our main result - an increase in wages of highly educated native workers while their employment is stable - could only be rationalized with inflows of high-wage natives from the control to the treatment regions. Unfortunately, we cannot examine flows of workers with the SSES data because it does not allow following individual workers over time. We thus investigate the question using data from the Swiss Labor Force Surveys. Overall, the analysis, presented in in Appendix C, provides no evidence that the greater availability of CBW affected the flow of natives between treated and control regions. In particular, we find no evidence of an increase in job-to-job transitions from the control to the treatment region - both for all workers and highly educated workers. Consistently, we find no influence of the reform on regional population size

\footnotetext{
${ }^{23}$ The basic intuition is to control for regional changes in employment or wages (by skill group) which are due to national-level changes in industries that are strongly represented in a particular region. See Appendix B.3 on the construction of this variable.

${ }^{24}$ Omitting the linear time trends reduces the point estimate of the effect on wages highly educated natives and its precision. This point estimate, however, is not statistically different from the baseline estimate.
} 
(column 6 of Table A.11).

Beerli and Peri (2018) provide several further robustness checks. Most importantly, the paper shows that the results are similar if we only compare changes in outcomes in municipalities in the highly affected area (0-15 min) with outcomes in matched control municipalities that are similar in terms of predetermined characteristics (an approach also followed by Dustmann et al., 2017). The labor market results are also similar if skills are measured using occupation (high-, middle- and low-paying occupations) instead of educational groups.

\section{Theoretical framework}

Our empirical findings in the previous sections show that opening the labor market for $\mathrm{CBW}$ in the municipalities close to the border produced an increase in the employment of these workers, especially the highly educated ones. Nevertheless, the reform led to an increase in the wages of highly educated native workers. These findings run counter to an interpretation of the reform as an increase in the local supply of high-skilled workers in a classic supply and demand framework within a perfectly competitive labor market (as used in Borjas, 2014, Chapter 3). In such a framework, an increase in high skilled foreign workers would decrease wages for high skilled native workers, at least in the short run. Moreover, such a framework is not well suited to describe how the removal of mobility restrictions affects job creation by facilitating firms' access to a pool of highly skilled and initially scarce workers.

We thus prefer to conceptualize our findings in an imperfect labor market framework with firm-employee matching, frictional search, and job posting (e.g., Pissarides, 2000; Chassambouli and Palivos, 2014; Chassambouli and Peri, 2018). In such a model, firms post vacancies while workers with different skills search for jobs. The presence of search frictions leads to unemployment in equilibrium, and the labor market for each skill type is characterized 
by a specific ratio of vacancies to unemployment, called labor market tightness. The tighter the labor market for a particular skill type, the harder is it for firms to fill their vacancies. It is natural to assume that the labor market for certain specialized workers such as R\&D workers is tighter. ${ }^{25}$ Consequently, firms that depend more heavily on these workers will on average face a tighter labor market. These firms will experience "skill shortage."

In such a framework, the reform reduces the tightness of the labor markets for skilled workers by gradually increasing the availability of skilled CBW, i.e. more job seekers start to search for jobs in the Swiss labor market close to the border. The reform thus leads to a higher matching and vacancy-filling rate for skilled jobs with CBW. This, in turn, leads to an increase in employment of those workers and a decrease of unfilled vacancies of the firm. Given the heterogeneity between firms in the use of specialized workers, we expect that these effects are particularly pronounced in firms that were more dependent on workers that were scarce before the reform. Over time, firms will expand in response to the greater availability of CBW and the number of vacancies will increase.

Such a model, however, cannot explain the observed increase in wages of high-skilled native workers: if the production function of the firm has constant or decreasing labor productivity, as in the standard Pissarides (2000) model, then the increase in employment of skilled CBW and the decrease in unfilled vacancies in the short run would lower wages of native skilled workers both through marginal productivity effects and through reducing skill-specific labor market tightness, which worsens workers' outside options when bargaining over wages. The observed positive wage effect on skilled natives, instead, requires that the production function of the firm exhibits increasing returns to high-skilled workers. This is true if highly educated CBW have positive effects on firms' total or skill-specific productivity and/or phys-

\footnotetext{
${ }^{25}$ As skilled workers have higher productivity and thus generate a higher surplus for the firm, firms will create a large number of job postings for them. At the same time, unemployment rates for skilled workers are lower due to long tenure in jobs (low break-up rates) and high specificity of matching.
} 
ical capital. In this case, a greater availability of skilled workers can increase firms' surplus of a match, stimulate job creation, and thus lead to higher wages for high-skilled workers.

The literature suggests several channels through which a greater availability of high-skilled CBW may positively affect firms' productivity and capital accumulation. First, there may be static and dynamic productivity effects from increasing the number skilled workers in a firm due to labor pooling, knowledge spillovers, and diffusion of ideas. ${ }^{26}$ Similarly, an increase in $\mathrm{R} \& \mathrm{D}$ specialized workers could stimulate productivity because it is a direct input in the innovation process of firms and in the creation of new knowledge, either through increased patenting (Kerr, 2013; Kerr et al., 2014) or the exchange of ideas (see Hunt, 2011; Hunt and Gauthier-Loiselle, 2010).

Second, an increase in specialized workers may trigger firms to adopt technologies that are better suited for using the skills supplied by CBW, increasing the specific productivity of that group (e.g., Peri, 2012; Hornung, 2014; Lewis, 2011). If skilled CBW and natives specialize in different jobs, this would attenuate possible negative effects on the marginal productivity of skilled native workers and enhance the positive wage effects on them from productivity changes. Third, an increase in high skilled workers may attract physical capital and induce firm-creation and investment (Kerr et al., 2015; Olney, 2013). ${ }^{27}$ If capital and skilled workers are complements (Krusell et al., 2000), the resulting increase in physical capital in the area would contribute to increase wages of skilled native workers.

Overall, the combination of search frictions in the (skilled) labor market, heterogeneous firm-level dependence on these workers, and positive produc-

\footnotetext{
${ }^{26}$ Moretti (2004) and Diamond (2016), among others, show that a larger share of college educated workers increases labor productivity in US cities. Glaeser and Mare (2001) show that this may be in part due to dynamic local learning. Iranzo and Peri (2009) argue that it may be the consequence of faster technology adoption.

${ }^{27}$ Theoretically, we expect that firms' entry and location choices under nonzero profits depend upon the same quantities as those that affect firms' sales and profits (Combes and Gobillon, 2015). The prospect of hiring the right type of workers can be a strong attractor for firms and a key driver of agglomeration economies (as in Moretti, 2004).
} 
tivity effects of high-skilled CBW are the key ingredients to understand our empirical findings. These theoretical considerations lead to a series of predictions regarding the effect of the policy that we test in the following sections mainly using firm-level data from the BC and the IS.

\section{Mechanisms}

A couple of remarks on the firm-level regressions are warranted before turning to these analyses. ${ }^{28}$ First, the unit of observation in the regressions is an establishment (in the Business Census, BC) or a firm (in the Innovation Surveys, IS). Second, we focus on incumbent firms because the free movement policy changed the composition of firms by affecting establishment creation in the heavily affected regions (as shown in section 7.4). In the BC, we thus restrict the sample to a fully balanced panel by focusing on establishments that existed in all sample periods. In the IS, balancing the panel would lead to a very small sample $(n \approx 100)$, so we focus on incumbents by restricting the sample to firms that existed before 1999. As can be seen in Table A.14 in the appendix, alternatives to account for firm entry lead to very similar results. ${ }^{29}$ Third, to ensure that the sample is comparable to what we used in the labor market analysis (based on the SSES), we focus on private-sector establishments and drop those with less than three FTE workers in the first census. For the same reason, we weight regressions based on the BC by establishment's average size over the sample. In the IS, however, our preferred regressions are not weighted by firm size. ${ }^{30}$ Fourth, in both datasets,

\footnotetext{
${ }^{28}$ Section B.2 in the appendix contains a detailed discussion on the construction of our firm-/establishment level estimation samples. For ease of exposition and brevity, we mainly focus on the preferred specifications of Ruffner and Siegenthaler (2017). We refer the reader to this working paper for a full discussion how the specification choices influence the main results.

${ }^{29}$ One is to include all firms that fulfil the other sample restrictions (i.e. to allow firm entry and exit) and to account for entry using the firm/establishment fixed effects only (panel G). Another is follow a single cross-section of firms (such as those existing in 1998, panel $\mathrm{H})$.

${ }^{30}$ Weighting by firm size is unattractive in the IS because it gives a large weight to the few, large multi-establishment firms in the survey. In the IS, we assign multi-establishment firms to the location of the headquarter, which leads to mismeasurement (see section 3.1). Table A.16 compares the weighted and the unweighted regression results. The effects have
} 
we drop a very small number of extreme outliers which significantly affect the precision, but not the estimate of the coefficient of interest (as shown in Table A.14). Finally, for brevity, the control group will mainly be firms in the BR 30+ minutes away from the border. Both control groups lead to similar results with few exceptions that we discuss (Figures A.1 and Table A.14 provide a direct comparison).

\subsection{Effects by skill-intensity of industries}

This section assesses a first set of predictions from our theoretical considerations: the greater availability of workers should lead to additional hiring of CBW and stimulate the creation of additional jobs within firms. Since most new CBW are skilled, these effects should be most prevalent in firms whose production is more intensive in skilled workers. To test these predictions, we examine how the reform affected employment in establishments separately for low- and high-tech manufacturers, and knowledge-intensive (finance, business, human resource management) and more traditional service sector establishments.

The results, based on the balanced panel of establishment from the $\mathrm{BC}$, are presented in Figure 5. The dependent variable in panel A is log FTE employment (panel A). In panels B and C, the outcome is FTE employment of foreign workers (i.e., resident immigrants plus CBW) and Swiss workers, respectively. For consistency with the results in section 4 , we express these outcomes as shares of total FTE employment in 1998, but the results are comparable if we use an approximate log outcome (see Figure A.3 in the appendix). Because the $\mathrm{BC}$ in 1991 and 2011 do not contain information on workers' nationality, panels $\mathrm{B}$ and $\mathrm{C}$ are restricted to the census waves 1995-2008.

Figure 5, first, suggests that highly treated establishments and control establishments displayed a similar within-establishment change in all these outcomes in the pre-reform period. According to panel B, high-treatment

the same sign, but the former are larger and more sensitive to the choice of specification. 
incumbent establishments began to hire more foreign workers than the control group starting in the 1998-2001 period. Consistent with our theoretical considerations, the hiring mainly happens in high-tech manufacturing and the knowledge-intensive service sector. As shown by panel $\mathrm{C}$, the increased employment of foreigners in skill-intensive sectors did not lead to a reduction in employment of Swiss nationals in the firms. Instead, highly treated incumbent establishments seem to have created additional jobs for the newly hired foreigners. This happened as early as in the transition phase, simultaneously to the increase in employment of CBW. By 2011, highly treated establishments in the two skill-intensive sectors are substantially larger than control establishments in the same sector.

Overall, we find strong evidence that the greater availability of CBW led to the creation of additional jobs for the newly available foreign workers. Averaged across all sectors, the free movement policy increased foreign employment as a share of 1998 employment in highly treated establishments by $8.5 \%$ and total FTE employment by $6.2 \%$, as shown in columns 1 and 2 of Table 4. The estimated reform effect on the size of incumbent firms in the IS are even slightly larger (column 3 of Table 4). Moreover, we generally find similar results if we use firms in the NBR as control group except that the effects on establishment size in the BC are almost exclusively driven by high-tech manufacturers (see Figures A.1 and A.2 in the appendix).

Table 5 tests another implication of our theoretical considerations: if the reform's positive wage effects are due to increased productivity or capital accumulation in firms, the sectors that have the largest increase in employment of CBW should also account for natives' wage gains. The table shows that the wage increase of natives are indeed concentrated in high-tech manufacturing and the knowledge-intensive service sector. Interestingly, if we estimate the sector-specific effects separately by natives' educational attainment, we find that the wage gains in the knowledge-intensive service sector accrue to highly educated natives only. The evidence is more mixed in high- 
Figure 5: Effect of free movement policy on FTE employment of incumbent establishments

\section{A. Total FTE employment}

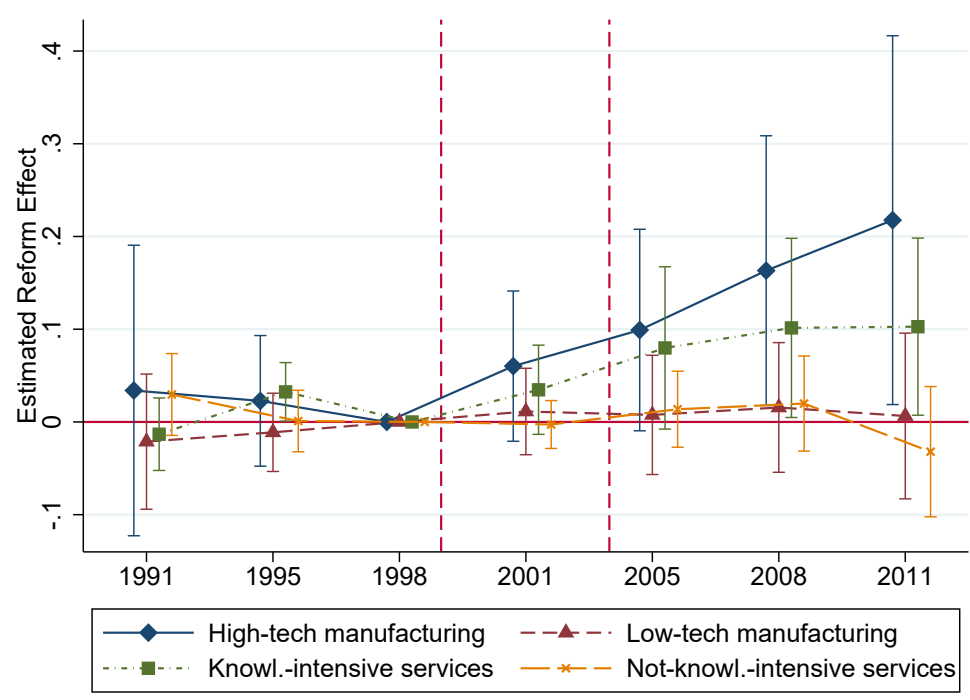

B. FTE employment of foreigners

C. FTE employment of natives relrelative to FTE employment in 1998 ative to FTE employment in 1998
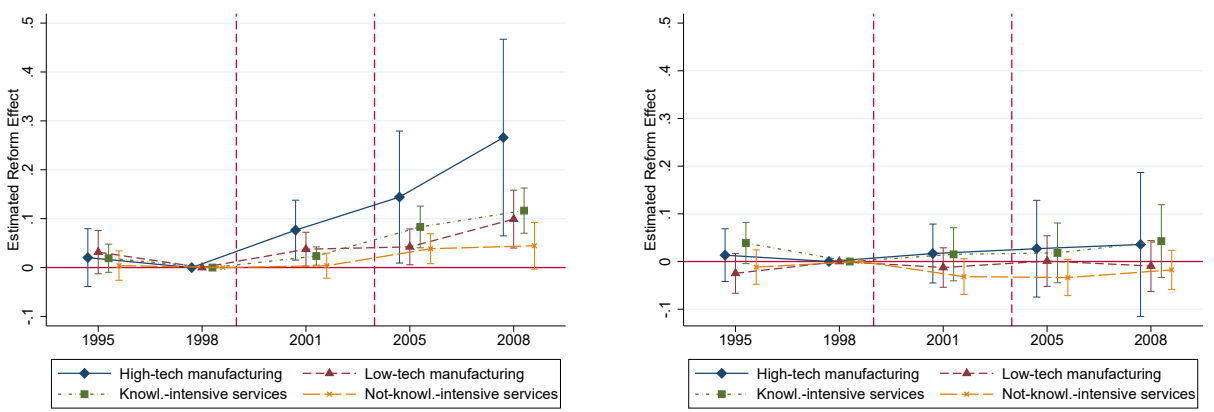

Notes: The figures show the effect of the free movement policy on FTE employment of incumbent establishments using private-sector establishment-level data from the BC. They plot event study coefficients and associated $95 \%$ confidence intervals for highly treated establishments based on equation (2), estimated separately by establishments' broad sector of economic activity. The regressions control for establishment fixed effects, year fixed effects, and linear NUTS-II trends. The control group is establishments in the BR with more than 30 minutes travel distance to the border (results using the other control group are presented in Figure A.2). In panel A, the dependent variable is log FTE employment. In panel B, it is FTE employment of foreigners as a share of total employment in 1998. In panel C, it is FTE employment of Swiss nationals as a share of total employment in 1998. (Figure A.3 provides the same regressions for an approximate log outcome.) The samples in panels B and C cover the 1995-2008 period because the BC in 1991 and 2011 do not contain information on workers' nationality. All regressions are weighted using average establishment size (in FTE). Standard errors are clustered by commuting zone. 
Table 4: Effect of free movement policy on various firm outcomes

\begin{tabular}{|c|c|c|c|c|c|c|c|}
\hline VARIABLES & $\begin{array}{c}(1) \\
\text { FE } \\
\text { Foreign } \\
\text { empl. }\end{array}$ & $\begin{array}{c}(2) \\
\mathrm{FE} \\
\text { Establ. } \\
\text { size } \\
\text { (FTE) }\end{array}$ & $\begin{array}{c}(3) \\
\text { FE } \\
\text { Firm } \\
\text { size } \\
\text { (FTE) }\end{array}$ & $\begin{array}{c}(4) \\
\text { FE } \\
\text { Sales }\end{array}$ & $\begin{array}{c}(5) \\
\text { FE } \\
\text { Produc- } \\
\text { tivity }\end{array}$ & $\begin{array}{c}(6) \\
\text { FE } \\
\text { Patent } \\
\text { appl. } \\
0 / 1\end{array}$ & $\begin{array}{c}(7) \\
\text { FE } \\
\text { Patent } \\
\text { appl. } \\
\text { count }\end{array}$ \\
\hline Transition $_{t} * I\left(d_{i} \leq 15\right)$ & $\begin{array}{c}0.025^{* * *} \\
(0.009)\end{array}$ & $\begin{array}{c}0.024 \\
(0.017)\end{array}$ & $\begin{array}{c}0.015 \\
(0.033)\end{array}$ & $\begin{array}{l}-0.004 \\
(0.036)\end{array}$ & $\begin{array}{l}-0.001 \\
(0.036)\end{array}$ & $\begin{array}{c}0.017 \\
(0.019)\end{array}$ & $\begin{array}{c}0.038 \\
(0.028)\end{array}$ \\
\hline Transition $_{t} * I\left(15<d_{i} \leq 30\right)$ & $\begin{array}{c}0.031^{* * *} \\
(0.007)\end{array}$ & $\begin{array}{c}0.049 * * * \\
(0.016)\end{array}$ & $\begin{array}{c}0.035 \\
(0.029)\end{array}$ & $\begin{array}{l}-0.008 \\
(0.033)\end{array}$ & $\begin{array}{l}-0.044 \\
(0.035)\end{array}$ & $\begin{array}{c}0.004 \\
(0.015)\end{array}$ & $\begin{array}{l}-0.022 \\
(0.028)\end{array}$ \\
\hline Free $_{t} * I\left(d_{i} \leq 15\right)$ & $\begin{array}{c}0.085^{* * *} \\
(0.020)\end{array}$ & $\begin{array}{c}0.062^{* * *} \\
(0.022)\end{array}$ & $\begin{array}{c}0.098^{* *} \\
(0.046)\end{array}$ & $\begin{array}{c}0.120^{* * *} \\
(0.050)\end{array}$ & $\begin{array}{c}0.037 \\
(0.035)\end{array}$ & $\begin{array}{c}0.064^{* *} \\
(0.027)\end{array}$ & $\begin{array}{c}0.126^{* * *} \\
(0.046)\end{array}$ \\
\hline Freet $* I\left(15<d_{i} \leq 30\right)$ & $\begin{array}{c}0.034^{* * *} \\
(0.012)\end{array}$ & $\begin{array}{c}0.055^{* *} \\
(0.023)\end{array}$ & $\begin{array}{l}0.091^{*} \\
(0.046)\end{array}$ & $\begin{array}{c}0.049 \\
(0.044)\end{array}$ & $\begin{array}{c}-0.042 \\
(0.039)\end{array}$ & $\begin{array}{l}0.018 \\
(0.024)\end{array}$ & $\begin{array}{c}0.039 \\
(0.050)\end{array}$ \\
\hline Observations & 252,962 & 358,619 & 9,250 & 8,456 & 7,107 & 9,032 & 8,901 \\
\hline R-squared & 0.616 & 0.955 & 0.965 & 0.973 & 0.729 & 0.710 & 0.820 \\
\hline Data set & $\mathrm{BC}$ & $\mathrm{BC}$ & IS & IS & IS & IS & IS \\
\hline Sample period & $95-08$ & $91-11$ & $95-12$ & $95-12$ & $95-12$ & $96-13$ & $96-13$ \\
\hline Period effects & $\sqrt{ }$ & $\sqrt{ }$ & $\sqrt{ }$ & $\sqrt{ }$ & $\sqrt{ }$ & $\sqrt{ }$ & $\sqrt{ }$ \\
\hline Firm/establishment effects & $\sqrt{ }$ & $\sqrt{ }$ & $\sqrt{ }$ & $\sqrt{ }$ & $\sqrt{ }$ & $\sqrt{ }$ & $\sqrt{ }$ \\
\hline Nuts-II trends & $\sqrt{ }$ & $\sqrt{ }$ & $\sqrt{ }$ & $\sqrt{ }$ & $\sqrt{ }$ & $\sqrt{ }$ & $\sqrt{ }$ \\
\hline Weights & $\sqrt{ }$ & $\sqrt{ }$ & & & & & \\
\hline Number of clusters & 72 & 72 & 73 & 73 & 71 & 73 & 73 \\
\hline
\end{tabular}

Notes: The table presents results of establishment- and firm-level DiD regressions using the BC (columns 1-2) and the IS (columns 3-7). The control group are firms in the BR with more than 30 minutes to the border (results using the other control group are presented in Panel B of Table A.14). The dependent variable in column 1 is full-time equivalent (FTE) employment of foreigners as a share of total employment in 1998. The dependent variable in column 2 is log FTE employment. The dependent variables in columns $3-5$ are firms' log FTE employment, log total sales, and log value added per FTE worker. The dependent variable in column 6 is a dummy equal to 1 if a firm filed at least one patent application in the year of the survey and the two years before the survey. Column 7 uses the Inverse Hyperbolic Sine (IHS) of the number of patent applications. Transition $t$ is a dummy equal to one between 1999 and 2003, whereas Freet is one from year 2004 onward. $I\left(d_{i} \leq x\right)$ and $I\left(y<d_{i} \leq z\right)$ indicate whether a firm is located less than $x$ travel minutes or between $y$ and $z$ travel minutes from the next border crossing, respectively. All regressions account for establishment (BC) or firm (IS) fixed effects, period fixed effects, and linear trends per NUTS-II region. The regressions in columns 1 and 2 are weighted using average establishment size (in FTE) as weight. ${ }^{* * *},{ }^{* *}$, *, denote statistical significance at the $1 \%, 5 \%$ and $10 \%$ level, respectively. Standard errors are clustered by commuting zone.

tech manufacturing along this dimension: the wage gains accrue to lower educated natives in the highly treated region but to highly educated natives in the weakly treated region. ${ }^{31}$ In contrast, we consistently find no wage effects on natives in the two sectors that are not skill-intensive. In fact, Table 5 provides evidence for non-negligible wage declines among the lower educated natives in non-knowledge intensive service industries. Those sectors are potentially those where capital and productivity effects were less pronounced, as technology is more traditional. Therefore, the increased labor market

${ }^{31}$ The results are similar if we use municipalities in the NBR as control group (see Table A.9 in the appendix). Why may lower educated natives have benefited from the reform in high-tech manufacturing but not in knowledge-intensive services? Differences in immigrant inflows by skills cannot explain this pattern-Table A.10 shows that the skill-ratios of immigrants are roughly similar in both sectors. One plausible answer is thus differences in complementarities in production across sectors. 
Table 5: Effect of the free movement policy on wage levels of natives by sector of employment

\begin{tabular}{|c|c|c|c|c|}
\hline \multirow[t]{3}{*}{ Category of employment } & \multicolumn{2}{|c|}{ Manufacturing } & \multicolumn{2}{|c|}{ Services } \\
\hline & High-tech & Low-tech & $\begin{array}{l}\text { Knowl.- } \\
\text { intensive }\end{array}$ & $\begin{array}{c}\text { Not-Knowl } \\
\text { intensive }\end{array}$ \\
\hline & $(1)$ & $(2)$ & $(3)$ & $(4)$ \\
\hline \multicolumn{5}{|c|}{ A. All education groups } \\
\hline Free $_{t} \cdot I\left(d_{m} \leq 15\right)$ & $\begin{array}{c}0.050^{* * *} \\
(0.016)\end{array}$ & $\begin{array}{c}0.015 \\
(0.018)\end{array}$ & $\begin{array}{l}0.040^{* *} \\
(0.017)\end{array}$ & $\begin{array}{l}-0.028 \\
(0.022)\end{array}$ \\
\hline Free $_{t} \cdot I\left(15<d_{m} \leq 30\right)$ & $\begin{array}{c}0.016 \\
(0.017)\end{array}$ & $\begin{array}{c}0.014 \\
(0.016)\end{array}$ & $\begin{array}{l}0.024^{*} \\
(0.012)\end{array}$ & $\begin{array}{l}-0.018 \\
(0.014)\end{array}$ \\
\hline
\end{tabular}

B. Highly educated

$\begin{array}{lcccc}\text { Free }_{t} \cdot I\left(d_{m} \leq 15\right) & 0.001 & -0.032 & 0.083^{* * *} & 0.031 \\ & (0.015) & (0.034) & (0.017) & (0.020) \\ \text { Free }_{t} \cdot I\left(15<d_{m} \leq 30\right) & 0.030^{* *} & -0.011 & 0.029^{*} & -0.014 \\ & (0.014) & (0.024) & (0.016) & (0.029)\end{array}$

C. Lower educated

\begin{tabular}{lcccc} 
Free $_{t} \cdot I\left(d_{m} \leq 15\right)$ & $0.042^{* * *}$ & 0.020 & 0.009 & $-0.037^{*}$ \\
& $(0.014)$ & $(0.018)$ & $(0.017)$ & $(0.020)$ \\
Free $_{t} \cdot I\left(15<d_{m} \leq 30\right)$ & 0.005 & 0.016 & 0.008 & $-0.029^{* *}$ \\
& $(0.017)$ & $(0.017)$ & $(0.012)$ & $(0.014)$ \\
\hline Year/Area fixed effects & $\sqrt{ }$ & $\sqrt{ }$ & $\sqrt{ }$ & $\sqrt{ }$ \\
Nuts-II trends & $\sqrt{ }$ & $\sqrt{ }$ & $\sqrt{ }$ & $\sqrt{ }$ \\
\hline \hline
\end{tabular}

Notes: This table shows the effects of the free movement policy on mean log hourly real wages of natives by education group and sector of employment based on equation (1). Municipalities in the BR 30+ constitute the control group (results using the other control group are presented in Table A.9). High-tech manufacturing is NACE Rev 1.1 industries 24, 29, 30, 31, 32, 33, 34 and 35 excluding 35.1. Low-tech manufacturers are the other manufacturing industries. Knowledge-intensive services are NACE Rev 1.1 industries $61,62,64,65-67,70-74,80,85,92$. Not knowledge-intensive services are the rest of the service sector industries. Freet is one from year 2004 onward. $\left(d_{i} \leq x\right)$ and $\left(y<d_{i} \leq z\right)$ indicate whether a municipality is located less than $x$ travel minutes or between $y$ and $z$ travel minutes from the next border crossing, respectively. Distance interactions with the transition phase are omitted for brevity. Regressions are weighted using the total number of natives in a cell. Robust standard errors, clustered by commuting zone, are given in parentheses. ${ }^{* *},{ }^{* *},{ }^{*}$, denote statistical significance at the $1 \%, 5 \%$ and $10 \%$ level, respectively. SESS data.

competition, especially from less-educated CBW, might have prevailed in the short run.

\subsection{Firm productivity}

Can we explain the wage increases of natives in the skill-intensive sectors established in the previous section with productivity gains in incumbent firms in these sectors, as hypothesized in section 6? As a first step to answer this question, columns 4 and 5 of Table 4 present the results of firm-level regressions of equation (1) using the log of firms' sales and value added per 
FTE worker as dependent variables. ${ }^{32}$ The data stem from the IS 19962013 but refer to the year before the survey. Column 4 suggests that the free movement policy increased sales of highly treated incumbent firms by almost $12 \%$. Despite of this sizable positive effect on sales, the liberalizations did not have a statistically significant impact on labor productivity of the average firm (column 5).

However, this average effect masks an increased productivity in the skillintensive sectors that account for the positive wage effect on natives. Panel A of Figure 6 presents the results of an augmented version of our baseline regression (column 5 of Table 4) that contains interactions between the treatment variables and dummy variables equal to one if a firm belongs to the two skill-intensive sectors. The regression controls for detailed industryperiod fixed effects so that we only compare firms in the same industry across regions. The figure suggests that the reform had a substantial positive effect on labor productivity of incumbent high-tech manufacturers in the free movement period. We also find a positive reform effect on the knowledgeintensive business service firms, but it is only statistically significant at the $10 \%$ level.

Another central prediction of our theoretical framework is that the productivity effects of the reform should be more pronounced in firms that faced particularly tight labor markets for skilled workers before the reform. We test this prediction leveraging the fact that firms in the IS were asked directly whether their innovation efforts were negatively affected by a "shortage of specialized personnel." We average the original, 5-point Likert scale survey item over the two survey waves prior to the reform for each firm and group firms into three categories, from "no shortage" to "high shortage." 33 As shown in Table 2, $17 \%$ of all highly treated firms and similar shares in the control regions experienced high skill shortages before the reform. In-

\footnotetext{
${ }^{32}$ The associated event study results are shown in Figure A.1.

${ }^{33}$ In particular, firms that have "no shortage" are firms with a less than 2, "moderate shortage" firms have a value between 2 and 4, and "high shortage" firms have a value greater than or equal to 4.
} 
terestingly, skill shortages appear to be broadly distributed across different segments of the economy: no single firm characteristic correlates strongly with firms' pre-reform problems to find skilled workers. ${ }^{34}$ If we interact the reform variables with the indicators of skill shortages - as is done in panel B of Figure 6 to test our theoretical prediction - we find strong evidence that the reform led to productivity gains in highly treated firms with skill shortages prior to the reform.

Panel $\mathrm{C}$ of Figure 6 leverages a similar subjective survey question to differentiate between firms that differed in the extent to which they reported that their innovation activities were hampered by "labor market regulation for foreigners" prior to the policy changes. Table A.22 in the appendix provides suggestive evidence that the reform reduced the probability that firms perceive to be hampered by this type of regulation. More importantly, Panel C of Figure 6 suggests that relaxing this obstacle spurred productivity growth in firms that were constrained initially.

Overall, the findings presented in this section provide support to the view that the wage gains of natives were the consequence of increased productivity in firms with high demand of skilled workers. They are also consistent with results from studies on the $\mathrm{H}-1 \mathrm{~B}$ program in the US, which typically find that changes in the number of $\mathrm{H}-1 \mathrm{~B}$ visas nationally affect productivity in firms and regions that rely strongly on H-1B workers (Ghosh et al., 2014; Kerr and Lincoln, 2010; Peri et al., 2015a).

\subsection{Innovation}

As discussed in section 6, another possible explanation for the positive wage effects of the open border policy is that the highly skilled CBW supported firms' innovation activities. To study this channel, we first analyze whether the newly hired CBW indeed play an important role in the growth of research and development (R\&D) departments of firms close to the border. Using

\footnotetext{
${ }^{34}$ See Table A.12 in the appendix. Firms that reported moderate or high shortages are slightly more likely to be manufacturers and to have R\&D expenditures.
} 
Figure 6: Effect of free movement policy on firms' sales, productivity, and innovation outcomes by dependence on skilled workers

A. Effect on sales and productivity by B. Effect on sales and productivity by broad sector pre-reform skill shortage
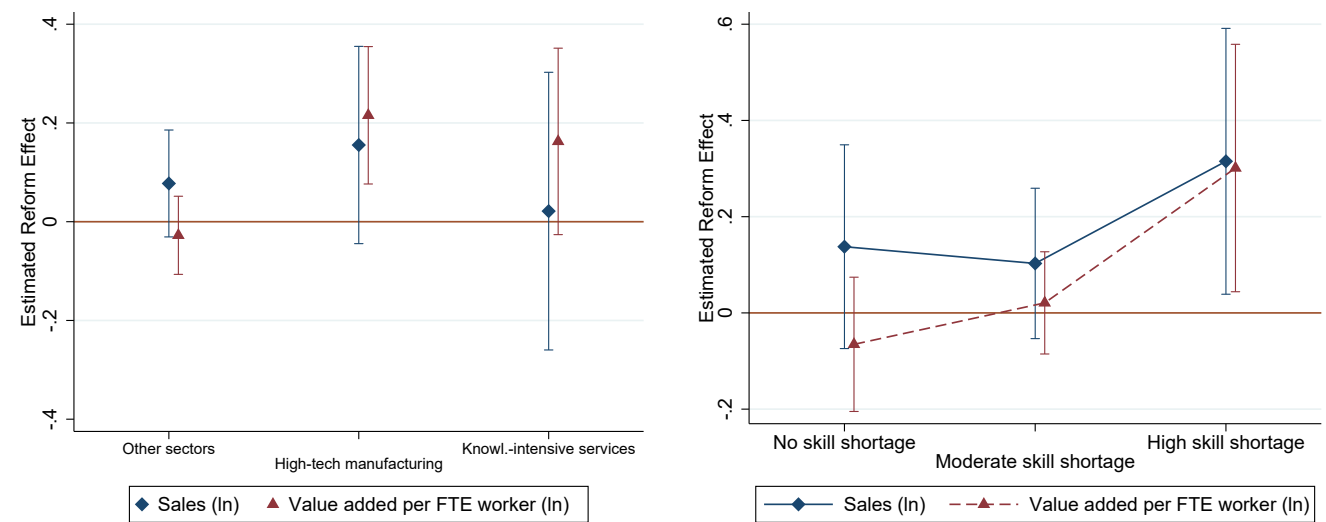

C. Effect on sales and productivity by D. Effect on innovation by pre-reform labor market regulation of foreigners R\&D shortage
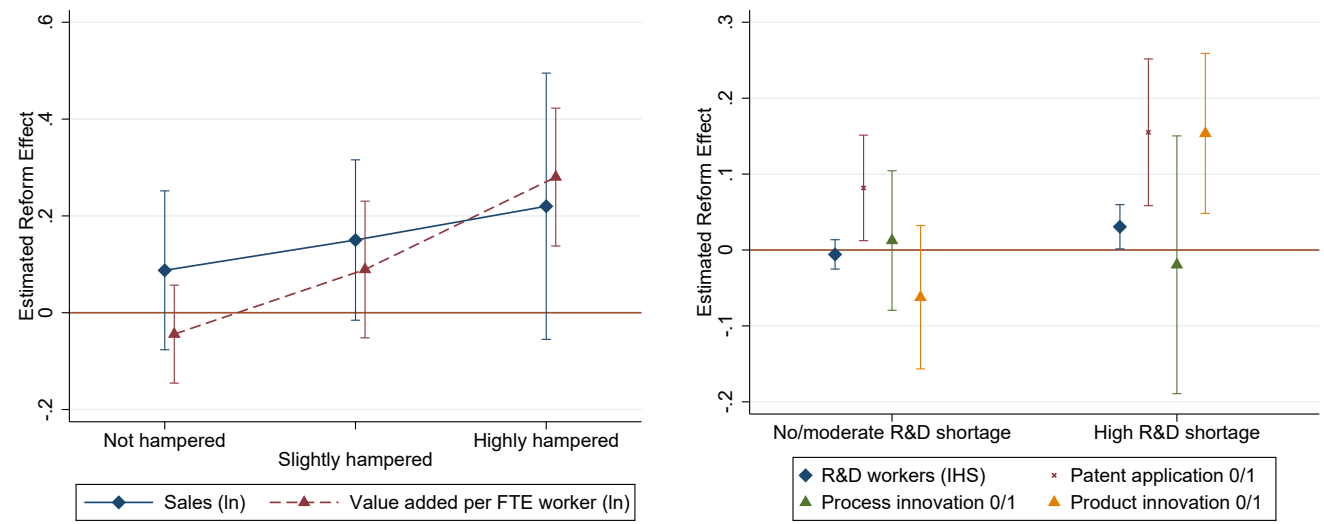

Notes: The figure examines whether the effects of the free movement policy on firms' sales, productivity and innovation depend on the skill-intensity of the sector and firms' perceptions to be constrained by labor shortages prior to the reform. All regressions are based on firm-level data from the IS 1996-2013, focus on the effects on highly treated firms in the free movement phase, and use firms in the BR located more than 30 minutes to the border as control group. The coefficients are derived from our baseline regression model (equation (1)) augmented with interactions between all reform variables and certain indicators. In panel $\mathrm{A}$, the indicators refer to knowledge-intensive service industries and high-tech manufacturers. In panels $\mathrm{B}, \mathrm{C}$ and $\mathrm{D}$, the indicators refer to firms that differed in the extent to which their innovation efforts were negatively affected by a "shortage of specialized personnel" (panel B), "labor market regulation for foreigners" (panel C), and "shortage of R\&D personnel" (panel D) in the IS 1996 and/or 1999. The dependent variables in panels A-C are log total sales and log value added per FTE worker. The dependent variables in panel D are the Inverse Hyperbolic Sine (IHS) of the number of R\&D workers, and dummies equal to 1 if a firm filed at least one patent application, reports to have introduced at least one process, or at least one product innovation in the three years preceding the survey. All regressions control for firm fixed effects, year fixed effects, and NUTS-II trends. Panel A also controls for industry-period effects. The vertical bars represent $95 \%$ confidence intervals constructed based on standard errors clustered by commuting zone. 
data from the SSES, panel A of Figure 7 plots the share of researchers in total employment depending on the travel distance to the border in 1996, 2000, and 2010. It illustrates that cross-border researchers represented almost one third of all R\&D workers in firms located within 15 minutes to the border in 2010. As for CBW in general, the presence of cross-border researchers declines strongly with distance from the border. The figure also documents an increase in the share of cross-border researchers between 2000 and 2010 that is concentrated close to the border, suggesting that the free movement policy increased the total R\&D employment share.

The regression analysis supports a causal interpretation of this effect. At the municipal level, we find that the free movement policy increased the share of immigrant researchers in total employment by about 0.6 percentage points (see Table A.4). We study the effect of the policy on total R\&D employment at the firm-level in panel D of Figure 6 using data from the IS 1996-2013. The dependent variable is the inverse hyperbolic sine (IHS) of the number of R\&D workers. ${ }^{35}$ The estimates thus reflect an approximate percentage increase. Guided by our theoretical considerations, we estimate separate effects for firms that were more or less affected by the tightness of the labor market for $R \& D$ workers prior to the reform. We distinguish firms that differed in the extent to which their innovation efforts were "hampered by lack of R\&D workers" in the IS 1996 and/or 1999. ${ }^{36}$ The latter represent 1/6 of all firms (see Table 2). The results in in panel D of Figure 6 suggest that the policy increased $R \& D$ employment in incumbent firms. As expected, the effect is driven by firms with more severe shortages of $R \& D$ workers before the reform.

Did the increase in $R \& D$ employment translate into more inventions?

\footnotetext{
${ }^{35}$ The inverse hyperbolic sine (IHS) of the number of patents accounts for the substantial amount of firms without patents and the long right tail of the distribution. The IHS of outcome $y$ is $\operatorname{IHS}(y)=\ln \left(y+\sqrt{1+y^{2}}\right)$. As argued by Doran et al. (2015), using the IHS is attractive for innovation outcomes because it approximates the log of an outcome but has the advantage that it is defined at 0 .

${ }^{36}$ Empirically, the effects for firms with no or moderate pre-reform R\&D shortage differ little, so we pool the two groups in the graph.
} 
Figure 7: Effect of free movement policy on R\&D employment and patenting

A. R\&D employment share by distance to border

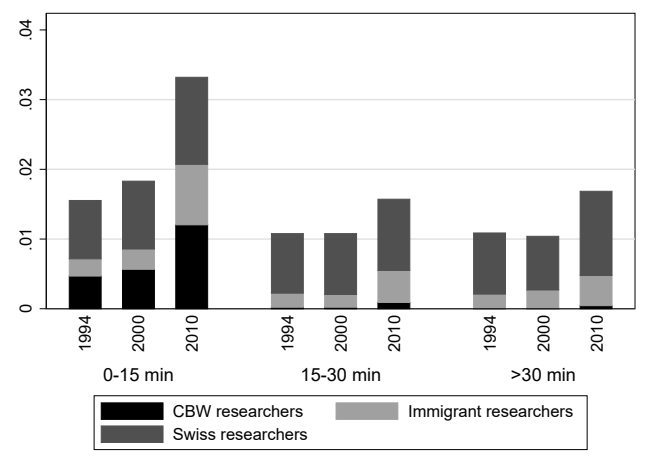

B. Effect of free movement policy on probability of patent application

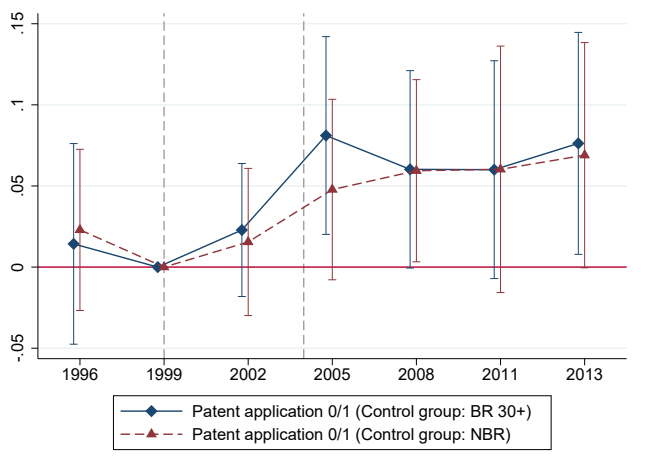

Notes: Panel A plots the employment share of workers in the occupation "research and development" by immigrant status and travel duration to the nearest border crossing, using data from the SSES in 1994, 2000, and 2010. The figure focuses on private-sector firms in the BR. Panel B plots the sequence of effects, and associated $95 \%$ confidence intervals, of the free movement policy on highly treated firms using firm-level data from the IS 1996-2013. The two event studies are based on separate regressions of equation (2) with the two control groups (municipalities in the BR located more than 30 travel minutes to the border and municipalities in the NBR). The dependent variables is a dummy equal to 1 if a firm filed at least one patent application in the year of the survey or the two years before the survey. The regression controls for firm fixed effects, year fixed effects, and NUTS-II trends. Standard errors are clustered by commuting zone.

The event study depicted in panel B of Figure 7 examines whether the reform affected the probability that highly treated firms filed at least one patent application in the three years before the IS. The figure provides robust evidence that the reform increased this probability. The estimated reform effect is approximately 6 percentage points relative to both control groups. The effect on the IHS of the count of patent applications is around 12 percent (see column 7 of Table 4). ${ }^{37}$ The difference in patent applications between firms in the highly treated and the control regions arises mainly between 2002 and 2005. Prior to the reform and from 2005 onward, the trends in patent applications are comparable. As shown in panel D of Figure 6, the effect on patenting is larger for firms that reported shortages of R\&D workers prior to the reform, consistent with the larger growth of R\&D employment in these firms.

Finally, panel D of Figure 6 also shows that the reform affected the actual output of the innovation process. In particular, we find that the reform had

\footnotetext{
${ }^{37}$ The corresponding event study is presented in panel D of Figure A.1. Table A.13 in the appendix shows heterogeneity analyses.
} 
a positive impact on the probability that firms report a product innovation in the IS. Product innovations are defined as the introduction of a good or service that is either new or a substantially improved version of a prior good or service. By contrast, we find no measurable impact on the probability to report process innovations, even among firms that lacked R\&D workers before the reform.

Overall, greater access to CBW seems to have increased employment of R\&D workers, patenting, and product innovations. These effects are concentrated among incumbent firms that declared shortages of R\&D workers before the policy implementation. Additional results reported in Ruffner and Siegenthaler (2017) show that the increase in employment of cross-border researchers had no measurable effect on employment and wages of native researchers and may have crowded in other resident immigrant researchers. These results add to an unsettled debate on whether inflows of skilled immigrants benefit high-skilled residents. Different studies on the impacts of $\mathrm{H}-1 \mathrm{~B}$ workers or foreign-born scientists reach conflicting conclusions. ${ }^{38}$ In the private sector context analyzed here, firms seem to have reacted to the greater availability of $R \& D$ workers by creating additional $R \& D$ jobs, which helped to absorb the increased supply of CBW.

\subsection{Capital adjustments}

Our theoretical considerations suggest that the increased availability of CBW could lead to higher capital formation and firm creation. If capital is complementary to high skilled workers, capital deepening could also have con-

\footnotetext{
${ }^{38}$ The results in Ghosh et al. (2014) and Kerr and Lincoln (2010) suggest that greater access to $\mathrm{H}-1 \mathrm{~B}$ workers generally increases the size, productivity, and innovation performance of firms that rely heavily on H-1B visas. Doran et al. (2015), on the other hand, find that winning an additional H-1B worker in the H-1B lotteries of 2006 and 2007 increased firms' profits, had no effect on patenting and firm size and crowded out resident workers. Similarly, Kerr et al. (2015) find that hiring young skilled immigrants increases firms' skill intensity, but their evidence regarding firm size is inconclusive. Finally, Borjas and Doran (2012) find that the strong influx of Russian mathematicians after the collapse of the Soviet Union had negative effects on the academic positions of US mathematicians. As pointed out by Card and Peri (2016), immigrant and resident mathematicians likely compete for a fixed number of positions in academia even in the medium run, which increases the scope for displacement.
} 
tributed to wage growth of highly educated workers.

We study the impacts on capital formation mainly by looking at entry and exit of establishments as observed in the $\mathrm{BC}$ data. In every census, an establishment is considered an entrant (an exiter) if its establishment identifier is new (disappears). The estimations are run at the municipal level and cover the period 1991-2008 in the case of firm entry and the period 1991-2011 in the case of firm exit. ${ }^{39}$ Figure 8 presents separate event study regressions for the two control groups based on these information. The outcome variable in panel $\mathrm{A}$ is the number of establishments entering a municipality between BC waves $t-1$ and $t$ relative to the number of establishments in 1998 . The outcome variable panel $\mathrm{B}$ is the number of establishment exits per municipality relative to the number of establishments in 1998. The regressions are weighted by the number of establishments in a municipality in 1998 .

The figure provides evidence that the reform had a positive impact on establishment entry. By 2008, the policy seems to have increased the share of new establishments in the highly treated region by roughly 4 percentage points relative to 1998. Importantly, this firm entry appears to have occurred early during the reform. It starts in the 2001-2005 period if we use municipalities in the NBR as the control group, and even in the 1998-2001 period if we use firms in the BR located far away from the border. In line with our previous results, the increase in firm-creation was most pronounced in high-tech manufacturing and in knowledge-intensive services, as shown in columns $2-5$ of Table A.19. We find no evidence that the reform affected establishment exit (panel B of Figure 8). This finding also limits the danger that our firm-level regressions are affected by survivorship bias. ${ }^{40}$

Two further results suggest that the greater availability of CBW affected

\footnotetext{
${ }^{39}$ The reason for the difference in sample coverage is given in Appendix B.2.

${ }^{40}$ This bias could mean that we attribute too much - or not enough - of the reform effect to occur within firms rather than to the change in firms' composition. Ruffner and Siegenthaler (2017) present additional robustness checks to address this concern, e.g., by constructing lower bounds on the reform effects using a trimming procedure proposed by Lee (2009).
} 
Figure 8: Effect of free movement policy on establishment entry and exit

A. Establishment entry

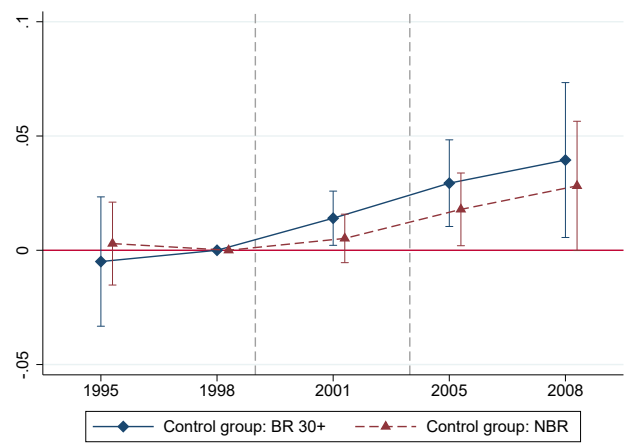

B. Establishment exit

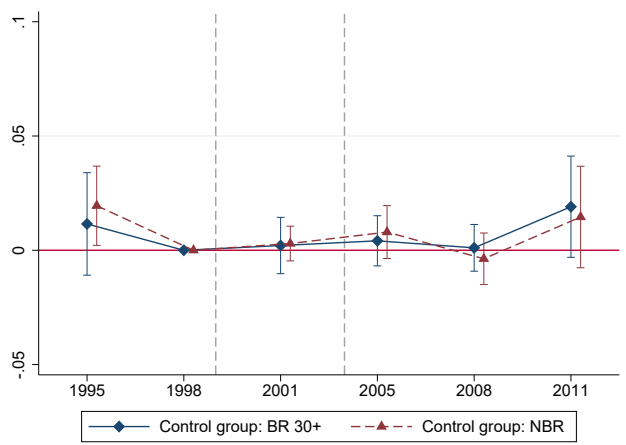

Notes: The figures plot the sequence of effects, and associated $95 \%$ confidence intervals, of the free movement policy on highly treated municipalities. The two event studies per panel are based on separate regressions of equation (2) with the two control groups (municipalities in the BR located more than 30 travel minutes to the border and municipalities in the NBR). In panel A, the dependent variable is the number of new establishments in $t$ as a fraction of the number of establishments in 1998. The estimation sample is based on municipality-level data from the BC 1991-2008. In panel B, the dependent variable is the number of establishments exiting between $t-1$ and $t$ as a fraction of the number of establishments in 1998. The estimation sample is based on the BC 1991-2011. Regressions are weighted using the number of establishments in 1998 per municipality as weight. All regressions include municipality and year fixed effects and NUTS-II trends. Standard errors are clustered by commuting zone.

firms' capital investment. First, Ruffner and Siegenthaler (2017) present suggestive evidence that the reform led to a decrease in firms' propensity to outsource production and service tasks in the BR. Second, Table A.20 in the appendix shows that the reform influenced the staffing decisions of multi-establishment firms. The table presents DiD estimates that focus on multi-establishment firms with branches in different regions. We find that the reform increased the growth of establishments located close to the border relative to establishments within the same firm in the two control regions. This suggests that the firms responded to the policy by increasing the size of establishments where CBW became more easily available.

Overall, the results indicate that the greater access to CBW encouraged capital formation. The resulting increase in labor demand appears to have taken place simultaneously with the increase in the supply of CBW, possibly because of the early announcement and permanent nature of the reform. These results are consistent with those of Olney (2013) who finds a quick response of establishment formation in low-skill intensive industries to an immigration-induced shock in low-skill labor supply. They are inconsistent, 
however, with evidence suggesting that spatial adjustments to immigration may take a long time to occur (see Jaeger et al., 2019, p. 10 f.). The results also raise the possibility that the effects identified in this study may partly represent relative rather than absolute causal effects. Without the reform, some firms that located close to the border may have located further away from it. Similarly, the growth in establishments close to the border within multi-establishment firms may have occurred at the expense of establishments further away. However, such a reallocation would likely lead to systematic flows of native workers to the highly treated and away from the control regions. Yet, we find no evidence that this happens (see Appendix C). Such a reallocation would also likely lead to a relative reduction in employment of natives in control compared to highly treated incumbent establishments. Panel $\mathrm{C}$ of Figure 5 suggests that this did not happen, either. Relative reallocation of workers and firms, therefore, if present at all, was likely quite small.

\subsection{Robustness of firm results}

We perform a similar set of robustness checks for our firm results as done for the labor market results. These checks reveal that our estimates are robust to the exclusion of the most important large cities (Table A.17) and the exclusion of the linear time trends contained in our baseline regression model (panel C of Table A.14). The estimated reform effects are also similar if we add industry-period, NUTS-II-period, and canton-period fixed effects (panels D-F of Table A.14) — controls that absorb many unobserved regionand industry-specific shocks that could confound the main results.

We paid particular attention to ensure that the estimated effects are not driven by changes in trade and market access, and, more generally, by the other bilateral agreements signed at the same time as the AFMP. ${ }^{41}$ As mentioned above, one of these agreements aimed at facilitating trade with

\footnotetext{
${ }^{41}$ In Ruffner and Siegenthaler (2017), we also check that the results are not driven by movements in the exchange rate. In general, the exchange rate remained relatively constant in the period of interest in this paper.
} 
the EU by reducing non-tariff barriers to trade. Moreover, Table 2 shows that the share of exporters and importers is slightly larger in regions close to the border. If the agreement affected firm and productivity growth in Switzerland, the effects are plausibly larger in regions close to the border.

Several pieces of evidence suggest that neither trade flows nor any of the other bilateral agreements drive our results. First, we find very limited evidence that the reform effects on firms were larger for firms that export more (see Figure A.4 and panel C of Table A.13 in the appendix). Second, we find no evidence that the reform affected firms' export status and export intensity. Rather, the results suggest that exports grew in parallel to domestic sales of treated firms (Table A.21). Third, our firm and labor market results are similar - if anything even stronger - if we exclude all two-digit industries that were directly affected by the other bilateral agreements (see panel D of Table A.6 and panel F of Table A.14). ${ }^{42}$ Fourth, using a set of qualitative questions in the IS about which policy-related factors hampered firms' innovation efforts, we show that there were no other changes in firms' political and regulatory environment (such as the access to the EU market) that changed differently between treated and control firms in the period of interest. Only one factor correlates systematically with the variables of interest (see Table A.22): the probability that firms perceive their innovation activities hampered by "labor market regulation for foreigners." This is likely a direct consequence of the labor market liberalizations.

Overall, these results suggest that factors such as the other bilateral agreements are unlikely to be a main driving force behind our results. Nevertheless, we cannot rule out that there are some other factors that may have contributed to differences in the growth of certain outcomes between the re-

\footnotetext{
${ }^{42}$ We proxy exposure to these agreements using a classification by Bühler et al. (2011) who study how the trade liberalization caused by the bilateral agreements affected plant growth in Switzerland. The authors carefully assess the extent to which a specific twodigit industry was affected by the six other bilateral agreements next to the free movement agreement. The authors assign industries into three categories: not affected, affected, and strongly affected. In the table, we only keep non-affected industries.
} 
gions of interest, especially given the relatively gradual implementation of the policy and the focus on longer-term outcomes. Arguably, however, several of our heterogeneity analyses - such as the results in Figure 6-lend credibility to our empirical strategy: in the cross-section of firms, the reform effects are generally largest among firms that we may expect to profit most from a better access to skilled foreign workers.

\subsection{Moving up the management ladder}

Finally, we test a last adjustment channel consistent with our theoretical framework: the absorption of $\mathrm{CBW}$ with no adverse wage effects may be explained by a reallocation of natives across tasks, enhancing their complementarity to CBW. As highly educated CBW were primarily employed in technical, scientific, and engineering jobs, native workers had an incentive to move towards the higher end of managerial jobs (similar as in Peri and Sparber, 2011; Peri et al., 2015b). Our previous evidence on increased firm entry suggest that there may well be an increased demand for managers. As management positions require knowledge of local culture, laws and norms, and possibly a local network of contacts, these positions are typically more accessible to natives than to foreigners.

To analyze whether the reform affected natives' probability to pursue a management position, we use the Swiss Labor Force Surveys (SLFS) 19962009. ${ }^{43}$ The SLFS identifies workers that are in the top executive level ("Direktion/Geschäftsleitung") of a firm. In Table A.23 in the appendix, we estimate whether the free movement policy affected the number of native workers in executive boards. The results suggest that the reform increased the share and number of highly educated native workers in these positions. The estimated effect is sizeable: the likelihood that a native holds a top-tier position increases by 18 percent relative to the pre-reform average. We do not find evidence of an effect on the share of lower educated natives working

\footnotetext{
${ }^{43}$ We impose similar sample restrictions and use similar definitions regarding skill groups, worker characteristics, and geography as in the labor market analysis with the SSES data (see Appendix B.1).
} 
in top management positions. These findings suggest that high-qualified native workers were more likely to become top-tier managers, possibly as a consequence of the imperfect substitutability with CBW. Using a different identification strategy, Basten and Siegenthaler (2019) also find that the immigrant inflows in Switzerland in the 2002-2011 period caused natives to move towards jobs with higher managerial content.

Table 6: Effect of the free movement policy on wages of highly educated natives in different management ranks

\begin{tabular}{|c|c|c|c|c|}
\hline & \multirow{2}{*}{$\begin{array}{l}\text { All highly } \\
\text { educated }\end{array}$} & \multicolumn{2}{|c|}{ Wage by manag. rank } & \multirow{2}{*}{$\begin{array}{c}\text { Const. manag. } \\
\text { rank shares }\end{array}$} \\
\hline & & High and middle & Low and no & \\
\hline & (1) & (2) & (3) & (4) \\
\hline Free $_{t} \cdot I\left(d_{m} \leq 15\right)$ & $\begin{array}{c}0.045^{* * *} \\
(0.015)\end{array}$ & $\begin{array}{c}0.054^{* * *} \\
(0.016)\end{array}$ & $\begin{array}{c}0.014 \\
(0.016)\end{array}$ & $\begin{array}{c}0.033^{* * *} \\
(0.011)\end{array}$ \\
\hline Free $_{t} \cdot I\left(15<d_{m} \leq 30\right)$ & $\begin{array}{c}0.015 \\
(0.012)\end{array}$ & $\begin{array}{l}0.025^{*} \\
(0.014)\end{array}$ & $\begin{array}{l}-0.012 \\
(0.014)\end{array}$ & $\begin{array}{c}0.007 \\
(0.014)\end{array}$ \\
\hline $\begin{array}{l}\text { Year and area fixed effects } \\
\text { Nuts II trend }\end{array}$ & $\begin{array}{l}\sqrt{ } \\
\sqrt{ }\end{array}$ & $\begin{array}{l}\sqrt{ } \\
\sqrt{ }\end{array}$ & $\begin{array}{l}\sqrt{ } \\
\sqrt{ }\end{array}$ & $\begin{array}{l}\sqrt{ } \\
\sqrt{ }\end{array}$ \\
\hline
\end{tabular}

Notes: This table shows the effect of the free movement policy on mean log hourly real wages of highly educated natives in different management levels based on equation (1). Municipalities in the BR 30+ minutes constitute the control group (Table A.24 provides the results with municipalities in the NBR as control group). Column 1 reports the baseline effect on all highly educated natives. In columns 2 and 3 , highly educated natives are split into those with a high/middle and low/no management rank. Column 4 reports the effect on all highly educated when the share of high/middle managers is hold at its 1998 level. This variable is the weighted average of the wages in high/middle positions $p, w_{m, t}^{p=h}$ and wages in low/no management positions, $w_{m, t}^{p=l}$ using the share of these groups' employment in $1998, \gamma_{m},^{\prime} 98=L^{p=h} / L$ and $\left(1-\gamma_{m,{ }^{\prime} 98}\right)$, as weights i.e. $\tilde{w}_{m, t}=w_{m, t}^{p=h} \gamma_{m,{ }^{\prime} 98}+w_{m, t}^{p=l}\left(1-\gamma_{m,{ }^{\prime} 98}\right)$. Freet is one from year 2004 onward. $\left(d_{i} \leq x\right)$ and $\left(y<d_{i} \leq z\right)$ indicate whether a municipality is located less than $x$ travel minutes or between $y$ and $z$ travel minutes from the next border crossing, respectively. Distance interactions with the transition phase are omitted for brevity. Regressions are weighted using the total number of natives in a cell. Robust standard errors, clustered by commuting zone, are given in parentheses. ${ }^{* * *}$, **, *, denote statistical significance at the $1 \%, 5 \%$ and $10 \%$ level, respectively.

How much of the positive reform effect on wages of high-qualified natives can be attributed to the increase in the share of better-paying management positions among them? We analyze this question in Table 6 using the SSES, which also contains information about the management rank associated to individuals' jobs. The first column reproduces our baseline effect on the wage of highly educated native workers in the free movement period. The next two columns show that this baseline effect is concentrated in higher management positions (column 2) in contrast to low/no management positions (column 3 ), corroborating the evidence that the reform increased the demand for 
workers in executive positions. In column 4, we calculate wages for highly educated natives holding the share of workers in management positions at its 1998 level. In this case, the estimated wage effect only amounts to $70 \%$ of the actual wage effect (cf. columns 1 and 4). This simple calculation indicates that roughly $30 \%$ of the wage growth of high-qualified natives arises because they moved to higher management positions.

\section{Conclusion}

This study sheds light on the effects of fully opening the Swiss labor market to CBW on the number and types of cross-border workers hired in Switzerland, on wages and employment of native workers, and on the number, employment, sales, productivity, and innovation activities of Swiss firms. Empirically, we exploit the sequential introduction of the free movement of persons and the fact that CBW mobility affected Swiss regions close to the border earlier and more strongly.

We show that the greater availability of CBW produced a progressive and significant increase in their employment in municipalities close to the border, while it had virtually no effect beyond 30 minutes driving distance from the border. Nevertheless, natives working in municipalities close to the border did not experience a statistically significant reduction in average log hourly wages, log employment, or log number of full-time equivalents after the liberalization, relative to municipalities further away from the border. Instead, we find evidence that wages of highly educated natives increased as a consequence of the reform, despite the fact that two thirds of the new CBW were also highly educated. We show that the positive wage effect resulted from pushing some of the natives to managerial and high-paying occupations, from stimulating productivity and job growth in incumbent firms, from attracting new firms, and from promoting firms' innovation activities. Most of these effects are most prominent in skill-intensive sectors and in firms that revealed shortages of skilled workers before the reform. 
Overall, our evidence is consistent with growth in number of jobs sufficient to absorb the CBW inflow without native displacement or wage decline.

Our results have at least three important insights that future research could extend. First, they highlight the important role of firms in determining the labor market effects of immigration. The policy changes affected the dynamics of capital investment, firm growth and productivity, indicating that firms recognized the opportunities created from a better access to highly skilled CBW. Second, our findings corroborate claims of business leaders that opening the border for foreign workers can benefit firms' performance. There has been little systematic research whether and which firms profit from increased access to foreign workers. Third, our results suggest that the gradual and predictable implementation of the reform may have played a central role in enabling adjustments by firms that allowed absorbing the increased supply of CBW. We encourage further studies that focus on changes in immigration policies to gain insights how immigration policy can foster firms' success without harming the labor market opportunities of native workers.

\section{References}

Aksu, Ege, Refik Erzan, and Murat G. Kirdar, "The Impact of Mass Migration of Syrians on the Turkish Labor Market," IZA Discussion Paper No. $12050,2018$.

BAK, "Bedeutung der Personenfreizügigkeit aus Branchensicht. Ergebnisse einer Unternehmensbefragung," Technical Report, BAKBasel Economic Research and Consultancy 2013.

Bartik, Timothy J, "Who Benefits from State and Local Economic Development Policies?," Books from Upjohn Press, 1991.

Basten, Christoph Carl and Michael Siegenthaler, "Do immigrants take or create residents' jobs? Evidence from free movement of workers in Switzerland," Scandinavian Journal of Economics, 2019, 121 (3).

Beerli, Andreas and Giovanni Peri, "The Labor Market Effects of Opening the Border: Evidence from Switzerland," NBER Working Paper No. 21319, Issued in July 2015, Revised in May 2018, 2018.

_, Ronald Indergand, and Johannes Kunz, "The Supply of Foreign Talent: How Skill-Biased Technology Drives the Skill Mix of Immigrants," KOF Working Papers, No. 436, 2017. 
Borjas, George J., "The labor demand curve is downward sloping: reexamining the impact of immigration on the labor market," The Quarterly Journal of Economics, 2003, 118 (4), 1335-1374.

_ , "Native internal migration and the labor market impact of immigration," The Journal of Human Resources, 2006, 41 (2), 221-258.

Borjas, George J, Immigration economics, Harvard University Press, 2014.

Borjas, George J. and Kirk B. Doran, "The collapse of the Soviet Union and the productivity of American mathematicians," The Quarterly Journal of Economics, 2012, 127 (3), 1143-1203.

B,S,S. Volkswirtschaftliche Beratung, "Schätzung der Kosten und Vereinfachung der Regulierungen im Bereich der Zulassung von ausländischen Erwerbstätigen zum schweizerischen Arbeitsmarkt," Technical Report, B,S,S. Volkswirtschaftliche Beratung 2013.

Bühler, Stefan, Marco Helm, and Michael Lechner, "Trade Liberalization and Growth: Plant-Level Evidence from Switzerland," University of St. Gallen, School of Economics and Political Science Working Paper No. 1133, 2011.

Card, David and Giovanni Peri, "Immigration Economics: A Review," unpublished manuscript, 2016.

Chassambouli, Andri and Giovanni Peri, "The Economic Effect of Immigration Policies: Analyzing and Simulating the U.S. Case," NBER Working Papers No 25074, 2018.

- and Theodore Palivos, "A search-equilibrium approach to the effects of immigration on labor market outcomes," International Economic Review, 2014, $55(1), 111-129$.

Colella, F., R. Lalive, S.O. Sakalli, and M. Thoenig, "Inference with Arbitrary Clustering," Mimeo University of Lausanne, 2018.

Combes, Pierre-Philippe and Laurent Gobillon, "The Empirics of Agglomeration Economies," in Gilles Duranton, J. Vernon Henderson, and William C. Strange, eds., Handbook of Regional and Urban Economics, Vol. 5A 2015, pp. 247-346.

Conley, Timothy G., "GMM estimation with cross sectional dependence," Journal of Econometrics, 1999, 92 (1), 1-45.

Diamond, Rebecca, "The Determinants and Welfare Implications of US Workers' Diverging Location Choices by Skill: 1980-2000," American Economic Review, 2016, 106 (3), 479-524.

Doran, Kirk B., Alexander Gelber, and Adam Isen, "The effects of highskilled immigration policy on firms: evidence from H1-B visa lotteries," NBER Working Paper No. 20668, 2015. 
Dustmann, Christian and Albrecht Glitz, "How do industries and firms respond to changes in local labor supply?," Journal of Labor Economics, 2015, 33 (3), 711-750.

_ , Uta Schönberg, and Jan Stuhler, "The impact of immigration: Why do studies reach such different results?," Journal of Economic Perspectives, 2016, $30(4), 31-56$.

_ , Uta Schönberg, and Jan Stuhler, "Labor Supply Shock and the Dynamics of Local Wages and Employment," The Quarterly Journal of Economics, 2017, $132(1), 435-483$.

Gerfin, Michael and Boris Kaiser, "The effects of immigration on wages. An application of the structural skill-cell approach," Swiss Journal of Economics and Statistics, 2010, 146 (4), 709-739.

Ghosh, Anirban, Anna Maria Mayda, and Francesc Ortega, "The impact of skilled foreign workers on firms: an investigation of publicly traded US firms," IZA Discussion Paper No. 8684, 2014.

Glaeser, Edward L. and David C. Mare, "Cities and Skills," Journal of Labor Economics, 2001, 19 (2), 316-342.

Henneberger, Fred and Alexandre Ziegler, "Empirische Überprüfung des Auftretens von Lohndruck aufgrund des Immigrationsdrucks aus den EU17/EFTA-Mitgliedstaaten," Diskussionspapiere des Forschungsinstituts für Arbeit und Arbeitsrecht an der Universität St. Gallen No. 125, 2011.

Hornung, Erik, "Immigration and the Diffusion of Technology: The Huguenot Diaspora in Prussia," American Economic Review, 2014, 104 (1), 84-122.

Hunt, Jennifer, "Which immigrants are most innovative and entrepreneurial? Distinctions by entry visa," Journal of Labor Economics, 2011, 29 (3), 417-457.

- and Marjolaine Gauthier-Loiselle, "How much does immigration boost innovation?," American Economic Journal: Macroeconomics, 2010, 2 (2), 3156.

Iranzo, Susana and Giovanni Peri, "Schooling Externalities, Technology, and Productivity: Theory and Evidence from U.S. States," The Review of Economics and Statistics, 2009, 91 (2), 420-431.

Jaeger, David A., Joakim Ruist, and Jan Stuhler, "Shift-Share Instruments and Dynamic Adjustments: the Case of Immigration," NBER Working Paper No. 24285, 2019.

Kerr, Sari Pekkala, William R. Kerr, and William F Lincoln, "Firms and the Economics of Skilled Immigration," NBER Working Paper No. 20069, 2014.

_, _, and William F. Lincoln, "Skilled Immigration and the Employment Structures of US Firms," Journal of Labor Economics, 2015, 33 (S1), S147S186. 
Kerr, William R., "U.S. High-Skilled Immigration, Innovation, and Entrepreneurship: Empirical Approaches and Evidence," NBER Working Paper No. $1937 r, 2013$.

Kerr, William R and William F Lincoln, "The Supply Side of Innovation: H-1B Visa Reforms and US Ethnic Invention," Journal of Labor Economics, 2010, 28 (3), 473-508.

Krusell, Per, Lee E. Ohanian, José-Víctor Ríos-Rull, and Giovanni L. Violante, "Capital-skill complementarity and inequality: a macroeconomic analysis," Econometrica, 2000, 68 (5), 1029-1053.

Lee, David S., "Training, Wages, and Sample Selection: Estimating Sharp Bounds on Treatment Effects," The Review of Economic Studies, 2009, 76, 1071-1102.

Lewis, Ethan, "Immigration, skill mix, and capital skill complementarity," The Quarterly Journal of Economics, 2011, 126 (2), 1029-1069.

Losa, Fabio Beniamino, Maurizio Bigotta, and Gonzalez Oscar, "La libre circulation: joies ou douleurs?," Technical Report 2014.

Mitaritonna, Cristina, Gianluca Orefice, and Giovanni Peri, "Immigrants and Firms' Outcomes: Evidence from France," European Economic Review, $2017,96(1), 62-82$.

Moretti, Enrico, "Workers' Education, Spillovers, and Productivity: Evidence from Plant-Level Production Functions," The American Economic Review, 2004, 94 (3), 656-690.

Moser, Petra, Alessandra Voena, and Fabian Waldinger, "German Jewish Émigrés and US invention," American Economic Review, 2014, 104 (10), 32223255 .

Müller, Tobias and Roman Graf, "The Effects of Free Movement of Persons on the Distribution of Wages in Switzerland," Mimeo, 2015.

Olney, William W., "Immigration and firm expansion," Journal of Regional Science, 2013, 53 (1), 142-157.

Ottaviano, Gianmarco I.P. and Giovanni Peri, "Rethinking the effects of immigration on wages," Journal of the European Economic Association, 2012, $10(1), 152-197$.

Paserman, M. Daniele, "Do high-skill immigrants raise productivity? Evidence from Israeli manufacturing firms, 1990-1999," IZA Journal of Migration, 2013, $2(1), 1-31$.

Peri, Giovanni, "The effect of immigration on productivity: Evidence from US states," Review of Economics and Statistics, 2012, 94 (1), 348-358. 
- and Chad Sparber, "Highly educated immigrants and native occupational choice," Industrial Relations: A Journal of Economy and Society, 2011, 50 (3), $385-411$.

_ , Kevin Shih, and Chad Sparber, "Foreign and native skilled workers: what can we learn from H1-B lotteries?," NBER Working Paper No. 21175, 2015.

_ , _ , and _ , "STEM workers, H1-B Visas and Productivity in US Cities," Journal of Labor Economics, 2015, 33 (S1), S225-S255.

Pissarides, Christopher A., Equilibrium unemployment theory, MIT Press, 2000 .

Ruffner, Jan and Michael Siegenthaler, "From Labor to Cash Flow? The Abolition of Immigration Restrictions and the Performance of Swiss Firms," SSRN Working Paper, KOF Swiss Economic Institute 2017.

Waugh, Michael E., "Firm Dynamics and Immigration: The Case of HighSkilled Immigration," in Gordon H. Hanson, William R. Kerr, and Sarah Turner, eds., High-Skilled Migration to the United States and its Economic Consequences, University of Chicago Press 2018, pp. 205-238. 


\section{Appendix}

\section{For Online publication}

\section{A The Swiss labor market around the time of the reform}

During the first half of the 1990s, Switzerland experienced a prolonged phase of economic stagnation. Employment fell by 3\% between 1991 and 1996 and registered unemployment increased to $5 \%$ in the mid-1990s. This unemployment rate was high in a historical perspective. Switzerland had official unemployment rates of almost $0 \%$ during many years of the post-war era. Consequences of the restructuring process associated with the economic stagnation in the early 1990s were an increasingly human capital-intensive economy and changes in the occupational and industrial structure, leading to an increase in the relative demand for skills (Puhani, 2005).

The macroeconomic situation improved in the late 1990s, with GDP picking up and the official unemployment rate falling below $2 \%$ in 1998. In this recovery, Swiss firms increasingly reported that they struggle to find suitable skilled workers. At the same time, the skill mix of new immigrants improved substantially relative to earlier periods (Beerli et al., 2017). The macroeconomic situation worsened when the dot-com bubble burst. Switzerland entered a phase of economic stagnation between 2001 and mid-2003. Unemployment increased to $3.5 \%$.

The stagnation phase ended towards the end of 2003. Switzerland entered a relatively extended boom phase with high GDP growth rates, falling unemployment, and very high employment growth relative to previous years. Even the Great Recession of 2007/2008 left only small marks in Switzerland. After a drop in 2009, the Swiss economy recovered fast and strongly. GDP grew at 3\% in 2010, more than offsetting the fall in the year before. Employment growth also picked up substantially in 2010 after a stagnation in 2009.

Overall, the number of employees increased by $15.2 \%$ between 2003 and 2013, from 4.2 to 4.8 million persons. A large part of this increase in employment was attributable to increased employment of EU workers. Switzerland's growth in hours worked in this period was remarkable even in international perspective. For instance, Germany, for which the recent surge in employment has been the subject of several studies, had lower employment growth than Switzerland from 2002 to 2013. Remarkably, Switzerland had high employment growth despite solid real wage increases. Siegenthaler et al. (2016) dubbed this phenomenon the Swiss "job miracle". 


\section{B Data construction}

Table A.1 provides an overview of the data sets, their samples, variables, and unit of analysis, as used in the labor market and the firm-level analysis, respectively.

\section{B.1 Sample construction and variables used for labor market analysis}

Swiss Earnings Structure Survey The analysis of the reform effects on immigration and on wages and employment of native workers is based on data from the Swiss Earnings Structure Survey (SESS). The SESS is a stratified random sample of private and public firms with at least 3 full-time equivalents from the manufacturing and service sectors. It is available in even years between 1994 and 2010 and covers between 16.6\% (1996) and 50\% (2010) of total employment in Switzerland. We restrict the sample and define the key variables as follows:

- Sample restriction in the SESS: The sample includes individuals with age between 18 and 65 years working in the private sector with non-missing information on nationality, place of work, education, wages, full-time equivalents, and other basic demographics. We only keep workers employed in private-sector firms, as the coverage of the public sector is not complete throughout our analysis period.

- Definition of immigrants and natives: The group we call resident immigrants hold either an L permit (4 to 12 months) or a B permit (1 to 6 years). Cross-border workers hold a G permit. Natives are individuals with Swiss nationality, either born in Switzerland or naturalized. The foreign-born individuals with a permanent residence permit (C permit) can be considered as long-time immigrants. This group excluded in our analysis, although they could reasonably be considered as native residents. We exclude them because some immigrants are likely to switch from an $\mathrm{L}$ or B permit to a $\mathrm{C}$ permit within our sample period. As we do not observe these changes in our data, we would have individuals that switch between immigrants and natives within the sample if we included long-time immigrants. Reassuringly, however, our labor market results are very similar if we count long-time immigrants as natives.

- Construction of real hourly wages and full-time equivalent employment: The dataset contains the gross monthly wage for each individual worker (in the month of October) in Swiss Francs. This measure includes social transfers, bonuses, and one-twelfth of additional yearly payments. We divide this measure by the number of hours worked in October, and use the consumer price index to deflate it into the real hourly wage of an individual worker at 2010 constant prices. When analyzing wage outcomes we trim our sample by excluding individuals with wages above the 99th percentile of real hourly wages in each year. We express full-time equivalent (FTE) employment as a fraction of the number of hours worked by a full-time worker, so that one unit is FTE.

- Assignment to border region and driving time to border: We use an official crosswalk from the Federal Statistical Office (FSO) to link zip codes of work places of workers in the SESS to municipalities. As the number of municipalities (and zip codes) changed over 
time due to mergers, we use the municipality definition in year 2000 as a time-invariant unit. Observations with outdated zip codes that could not be linked (less than $0.3 \%$ ) were dropped. We allocate municipalities to the border region and the non-border region as defined below for the firm-level analysis. Similarly, we use driving time to the nearest border crossing calculated for establishments $d_{i}$ in the business census (BC) averaged at the municipality level as $d_{m}$ using establishment employment in 1998 as weights.

- Firm tenure: Firms were asked to indicate each employee's affiliation with the firm in number of years. In the raw data, workers with less than one year of firm tenure are coded with a missing value between 1994 and 2002. Hence, we cannot distinguish workers with zero and missing values of firm tenure in these years. ${ }^{44}$ To adopt a consistent, albeit imperfect, definition of firm tenure, we recoded all missing and zero values to one in all years.

Swiss Labor Force Survey Since we cannot track individuals across years in the SESS, we use the Swiss Labor Force Survey (SLFS) as a complementary data set to investigate to which degree the effects on local employment can be decomposed into effects on in- and outflows of regional employment and their net effect (see Table A.11 discussed in Appendix C). The SLFS is the equivalent of the US Current Population Survey and was conducted in the second quarter of the year in our period of interest. It covers roughly $17^{\prime} 000$ individuals (or $0.5 \%$ of households) prior to 2002 and about 50'000 (1.5\%) from 2002 onward. As information on their municipality of work is available from 1996, we use yearly data between 1996 and 2009. In this period, most individuals were interviewed up to five consecutive years. We consider, however, only individuals' information in two consecutive years as only this sample is of meaningful size. Using information on the labor force status, place of work and other individual characteristics in two consecutive years, we can decompose the change in total private sector employment of natives in education group $e$ in municipality $i$ into its net-flows (in- minus outflow):

$$
L_{i, t+1}^{e}-L_{i, t}^{e}=\text { Netflow } w_{i, t+1, t}^{e}=I n_{i, t+1, t}^{e}-O u t_{i, t+1, t}^{e}
$$

Individuals are considered as inflows to local employment in municipality $m$ in year $t+1$, (1) if they were employed in another municipality in the same distance bin in $t,(2)$ if they were employed in a municipality located in another distance bin in the border region (0-15, $15-30,>30$ minutes) or in the non-border region in $t,(3)$ if they were not employed (either unemployed or out of the labor force) in $t$, or (4) if they were not in the sample. The latter group includes all individuals who were not covered in the SLFS or who were in the SLFS but did not belong to group e, e.g. they had another nationality status than native, they were not employed in the private sector, they were not in the relevant age range (18-64), they had a different education level, or they had a missing value in any of these variables. Outflows of local employment between year $t$ and $t+1$ are coded analogously. Using indi-

\footnotetext{
${ }^{44}$ From year 2002 onward, the survey instructed employers to indicate "zero years" in case a worker was employed less than one full year. No such instruction was given in the years 2000 and 1998. In 1994 and 1996, they were instructed to round to full years.
} 
viduals' average survey weight in the SLFS, we compute total group specific employment $L_{i, t}^{e}$ as well as total in- and outflow and their components (1)-(4), i.e. $I N_{i, t+1, t}^{e} \equiv \sum_{c=1}^{4} I N_{i, t+1, t}^{e, c}$ and $O U T_{i, t+1, t}^{e} \equiv \sum_{c=1}^{4} O U T_{i, t+1, t}^{e, c}$. The change in a municipality $i$ 's local employment between 1998 (the base year) and $T$ is then just the cumulative of the total yearly net-flows to this municipality which can be disaggregated into net-flows from components (1) to (4) i.e. $L_{i, T}^{e}-L_{i, 1998}^{e}=\sum_{t=1998}^{T-1} N_{\text {etflow }}^{e}{ }_{i, t+1, t}=\sum_{c=1}^{4} \sum_{t=1998}^{T-1}$ Netflow $_{i, t+1, t}^{e, c}$.

In the difference-in-difference regression framework with outcomes in levels, we can approximate the change in the log employment of a municipality by with its employment growth, i.e. the change in employment in between 1998 and year $T$ standardized with its employment in 1998, i.e. $\ln L_{i, T}^{e}-\ln L_{i, 1998}^{e} \approx \frac{L_{m, T}^{e}}{L_{i, 1998}^{e}}-\frac{L_{i, 1998}^{e}}{L_{i, 1998}^{e}}$. The latter can be decomposed into net-flows from (1)-(4) as follows:

$$
\frac{L_{i, T}^{e}}{L_{i, 1998}^{e}}-\frac{L_{i, 1998}^{e}}{L_{i, 1998}^{e}}=\frac{\left[\sum_{c=1}^{4} \sum_{t=1998}^{T-1} N e t f l o w_{i, t+1, t}^{e, c}\right]+L_{i, 1998}^{e}}{L_{i, 1998}^{e}}-\frac{L_{i, 1998}^{e}}{L_{i, 1998}^{e}}
$$

Table A.11 shows the effect of the reform on total local native employment by education group in column 1, i.e. the dependent variable is a municipalities current employment standardized with its employment in 1998, i.e. $L_{i, T}^{e} / L_{i, 1998}^{e}$. In the following columns the dependent variable is the standardized cumulative net-flows (1) from employment in other municipalities in same distance bin (column 2), [ $\sum_{t=1998}^{T-1} N$ etflow $\left.w_{i, t+1, t}^{e, 1}+\mathrm{L}_{i, 1998}^{e}\right] / L_{i, 1998}^{e}$, (2) from employment in municipalities in other distance bins (column 3), [ $\sum_{t=1998}^{T-1} N$ etflow $\left.{ }_{i, t+1, t}^{e, 2}+\mathrm{L}_{i, 1998}^{e}\right] / L_{i, 1998}^{e}$, (3) from non-employment (column 4), $\left[\sum_{t=1998}^{T-1} N\right.$ etflow $\left.w_{i, t+1, t}^{e, 3}+L_{i, 1998}^{e}\right] / L_{i, 1998}^{e}$, and (4) from out of the sample (column 5), $\left[\sum_{t=1998}^{T-1} N_{\text {etflow }}^{e, 4}, t+1, t+\mathrm{L}_{i, 1998}^{e}\right] / L_{i, 1998}^{e}$.

In subsection 7.6, we exploit the rich information in the SLFS to construct the share of workers by education group $e$ working in top executive boards ("Direktion/Geschäftsleitung") of a firm. Similarly as for the analysis of in- and outflows, we only use the years 1996-2009 in which we have information on the municipality of work of individuals.

\section{B.2 Sample construction and variables used for firm-level analysis}

Our firm-level estimation are based on the innovation surveys (IS) and the Swiss business censuses (BC). In the IS, the raw data contains answers for 1989, 2172, 2586, 2555, 2141, 2363, and 2034 firms for the seven years of the survey, representing an average response rate of $35 \% .{ }^{45}$ Moreover, the following comments on the construction of our analyses samples should be mentioned. Ruffner and Siegenthaler (2017) provide extensive sensitivity checks that show that our main results are not sensitive to imposing these sample restrictions:

- Sample restrictions in the $B C$ : Our analyses with the $\mathrm{BC}$ are based on all firms that participated in the censuses 1991-2011. We exclude establishments from the agricultural sector as well as public sector firms, as these sectors are not covered in the other datasets used in the analysis. Since the censuses do no provide information on the split between foreign and Swiss workers in 1991 and 2011, the results on the foreign employment share

\footnotetext{
${ }^{45}$ The questionnaires can be downloaded from www.kof.ethz.ch/en/surveys.
} 
are restricted to the 1995-2008 period. Moreover, the BC in 2011 is based on register data. Many variables available for the earlier waves are no longer available because of this change. Consequently, we update certain firm characteristics in 2011 using data from the same establishments in 2008.

- Deletion of microfirms in the $B C$ : In the BC, we discard firms with less than 3 FTE in 1998 in order to conform with the sample restrictions in the SSES. The population of firms sampled in the IS is firms with 5 or more FTE workers.

- Outliers: In both datasets, we discard a very small number of extreme outliers that have a strong leverage on the precision (not the point estimate) of the estimates. In the IS, we delete a small number of observations that report to have relocated from one year to another and at the same time report large changes in sales. Closer inspection of these cases revealed that most of them have implausibly large changes in sales and employment in one year. It is likely that some of these cases are due to changes in the reporting unit (e.g. from firm to establishment or vice versa). In the BC, we compute deviations from within-firm means in log FTE employment and discard all firms with observations that lie above the $99.9 \%$ quantile or below the $0.1 \%$ quantile of the distribution of this variable.

- Assignment of municipalities to border and non-border region: The border region is classified based on official documents of the Swiss Federal Statistical Office. In cases where no official documents were available, the classification is based on direct information gathered at cantonal statistical offices. The border region is slightly differently classified compared to previous studies (Losa et al., 2014) in the canton of Valais, based on information provided by the statistical office of the canton of Valais. All municipalities in the region Upper Valais and Lower Valais until Saint-Maurice (St-Gingolph, Port-Valais, Vouvry, Vionnaz, Collombey-Muraz, Monthey, Troistorrents, Val-d'Illiez, Champéry, Massongex, St-Maurice, Mex, Evionnaz, Salvan, Finhaut, Martigny-Combe, Orsières) are classified as border region. The other municipalities in the canton are classified as non-border region. The results are, however, not sensitive to the differential treatment of these municipalities.

\section{- Computation of distance to nearest border crossing}

For each unit (establishment or firm), we construct the distance (travel duration) to the nearest border crossing $\left(d_{i}\right)$ in minutes. In the $\mathrm{BC}$, these computations are based on the exact geographic coordinates of each establishment. In the IS, we use the zip code the questionnaire was sent to. We assign each establishment/firm to the location observed in 1998. The data on the location of border crossings in Switzerland necessary to construct $d_{i}$ come from Henneberger and Ziegler (2011) and refer to the year 2010. We also use the BC 1995 and 1998 to compute an employment-weighted distance to the border for each municipality.

- Assignment of units to border and non-border region: In the BC, we assign establishments to the border and non-border region based on the municipality code of each establishment. In the KOF innovation data, we assign firms to the BR and CR depending upon the 
address the survey was sent to. Because the unit of observation is a firm and not an establishment in the IS, multi-establishment firms are assigned to a treatment or control group based on the location of their headquarters. In both datasets, we exclude a very small number of firms located in municipalities where we could not establish whether they belonged to the $\mathrm{BR}$ or $\mathrm{CR}$.

- Measurement of establishment entry and exit: In every wave of the BC, an establishment is considered a new entrant if its establishment identifier is new. Exiting establishments are those whose identifiers disappears in the next $\mathrm{BC}$ wave. There are two reasons why we observe establishments with new establishment identifiers in the BC. The first is the actual creation of a new firm. The second is that a firm is created by a merger of incumbent firms. The former represents the large majority of cases. We count the number of entering and exiting establishments per municipality and $\mathrm{BC}$ wave to construct their share relative to the total number of establishments in a municipality in 1998. We analyze the effect on entrants using the years 1991-2008. For exiting establishments we use the years 19912011. We cannot use the census in 2011 in the firm entry analysis because this census uses a more encompassing definition of what counts as an establishment compared to the previous censuses. Therefore, many establishment entries between 2008 and 2011 result from the change in the definition, and we cannot identify those. 


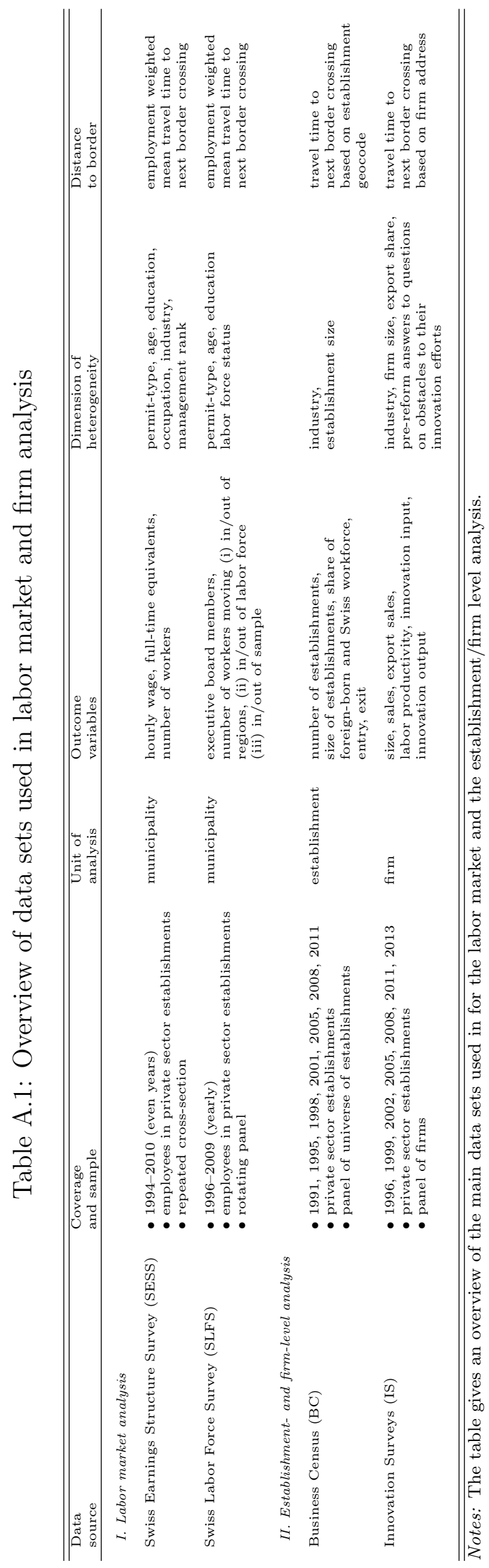




\section{B.3 Construction of Bartik control}

The Bartik control is a proxy for industry-driven local demand shocks. It absorbs local variation in employment or wages (by education group) resulting from national level changes of sectors which are strongly represented in a particular region. In other words, if, for instance, employment in a given industry increased (decreased) nationally, areas in which that industry represented a significant share of employment must have experienced a positive (negative) relative change in the demand for workers relative to those where that industry is not present. The Bartik control is defined at the level of the "commuting zone", which is an aggregation of municipalities often used to represent local labor markets. There are 106 commuting zones in the whole of Switzerland. We define the sector-driven employment growth for group $e$ in a commuting zone $c z$ in year $t$ as:

$$
\widetilde{E M P}_{c z, t}^{e}=\sum_{i \in\{1,50\}}\left(E M P_{i, c z, 1994}^{e} \times \frac{E M P_{-c z, i, t}^{e}}{E M P_{-c z, i, 1994}^{e}}\right)
$$

where $E M P_{i, c z, 1994}^{e}$ is the employment level of group $e$ (which could be, alternately, all workers or a specific education group of workers) in commuting zone $c z$ and (2-digit) industry $i$ in the earliest available year, 1994. $\frac{E M P_{-c z, i, t}^{e}}{E M P_{-c z, i, 1994}^{e}}$ is the group employment growth factor between 1994 and year $t$ for the industry nationally, excluding the commuting zone $c z .{ }^{46}$

When we consider the wage as outcome, we use a Bartik measure also based on national wage growth:

$$
\widetilde{w_{c z, t}^{e}}=\sum_{i \in\{1,50\}} s_{i, c z, 1990}\left(w_{i, c z, 1994}^{e} \times \frac{w_{-c z, i, t}^{e}}{w_{-c z, i, 1994}^{e}}\right)
$$

where $w_{i, c z, 1994}^{e}$ is the initial log hourly wage payed in (2-digit) industry $i$ for education group $e$ in commuting zone $c z$ in the first available wave in 1994 and $\frac{w_{-c z, i, t}^{e}}{w_{-c z, i, 1994}^{e}}$ measures industry wage growth for that group on the national level (excluding commuting zone $c z$ ). Wage growth is aggregated using each industry's employment share in $1990 s_{c z, i, 1990}$ taken from the national Census.

\section{Analysis of worker flows}

To interpret the estimates of the reform effects on wages and employment by natives as causal, workers in the control group must not be affected by the inflow of CBW due to the reform. This condition would be violated if native workers responded to the inflow of CBW by moving from treated to the control municipalities or vice versa, hence questioning our assumption that the latter constitute a valid control group. ${ }^{47}$

\footnotetext{
${ }^{46}$ From the list of industries, we dropped the industry 'Recycling' which was not available in all years.

${ }^{47}$ In the case of flows from the treatment to the control region, employment would increase in the control region and wages would fall, attenuating (overstating) the effects on wage (employment) that the regional comparison in the DiD may detect (see discussion in Dustmann et al. (2017)). The absence of strong negative employment effects on any group of native workers in our case make this particular concern less plausible. However, flows of highly skilled natives in the reverse direction, from the control region to the treatment region as a response to the inflow of $\mathrm{CBW}$, could be consistent with the positive wage and employment effects we find, if effects from human capital externalities outweigh competition effects among highly skilled (see e.g. Moretti, 2004).
} 
To investigate the importance of such worker flows, we use the Swiss Labor Force Survey, a complementary data set available yearly between 1996 and 2009. Most individuals in the SLFS were interviewed for two consecutive years. We exploit information on each worker's place of work and employment status in the previous year (next year) to total calculate the number of workers flowing in or out of local employment. This allows decomposing a municipality's change in local employment between 1998 and any other year $T$ into the sum of yearly net-flows (1) from employment in other municipalities in the same distance bin, (2) or from other distance bins (including the control group, the BR 30+ or the NBR), (3) from non-employment or (4) from out of the sample between 1998 and $T .^{48}$

The estimates presented in Appendix Table A.11 show no differential changes in total netflows in both treatment regions compared to both control groups (BR 30+ in panel I.A and NBR in panel II.D). For highly educated natives, the increase we observe in their employment when the BR 30+ constitutes the control group is consistent with an increased net-inflow from nonemployment. When municipalities in the NBR constitute the control group, however, estimates do not allow a clear conclusion. For lower educated workers changes in employment are generally lower and the estimates effects on their net-flows are not very robust across different control groups. These results are consistent estimates in column 6, which shows that the reform did not lead to significant changes in population size of municipalities in the treated regions.

\footnotetext{
${ }^{48}$ The last category, for instance, includes workers that move to public sector employment, drop out of our age range 18-64, etc. See Appendix B.1 for details on construction of these variables.
} 


\section{Appendix figures}

Figure A.1: Effect of free movement policy on various outcomes of incumbent firms, by control group

\section{A. FTE employment}

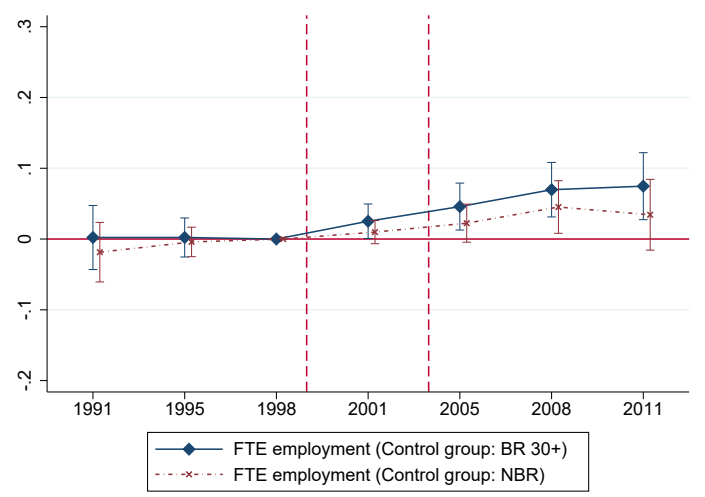

C. Value added per FTE worker

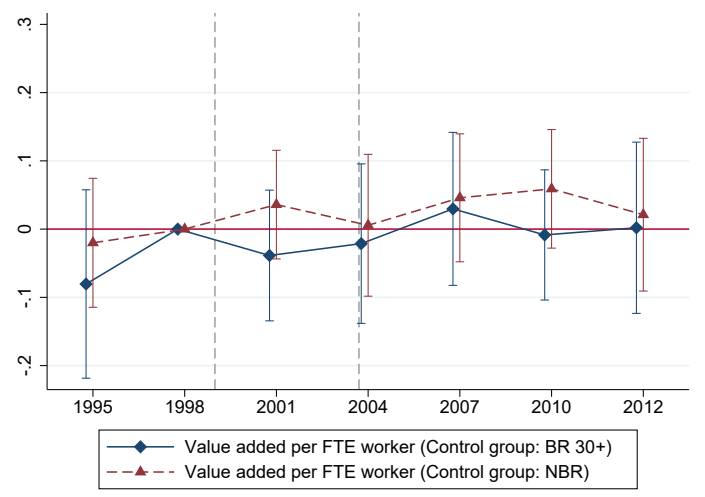

B. Sales

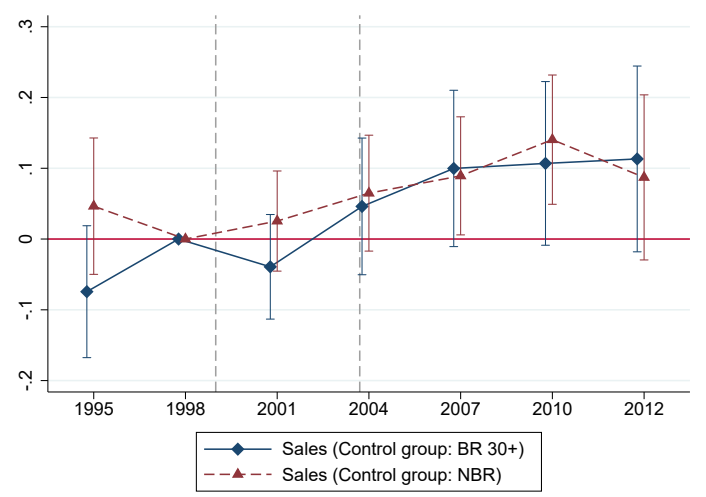

D. Number of patent applications



Notes: The panel plot the sequence of effects, and associated $95 \%$ confidence intervals, of the free movement policy on highly treated private-sector firms. The event studies are based on separate regressions of equation (2) using either of the two control groups (municipalities in the BR located more than 30 travel minutes to the border and municipalities in the NBR), as indicated in the legend. The regressions in panel A are based on establishment-level data from the BC 1991-2011. The dependent variable is log total FTE employment. The dependent variable in panel B is log total sales earned in year before the innovation surveys (IS) 1996-2013. The dependent variable in panel $\mathrm{C}$ is $\log$ value added per FTE worker in the year before the IS 1996-2013. The dependent variable in panel D is the IHS of the number of patent applications that a firm filed in the year of the survey and the two years before the surveys 1996-2013. The regressions in panel A are weighted using average establishment size (in FTE) as weight. All regressions control for firm fixed effects, year fixed effects, and NUTS-II trends. Standard errors are clustered by commuting zone. 
Figure A.2: Effect of free movement policy on FTE employment of incumbent establishments by broad sector (control group: NBR)

\section{Total FTE employment}



B. FTE employment of foreigners relative to FTE employment in 1998

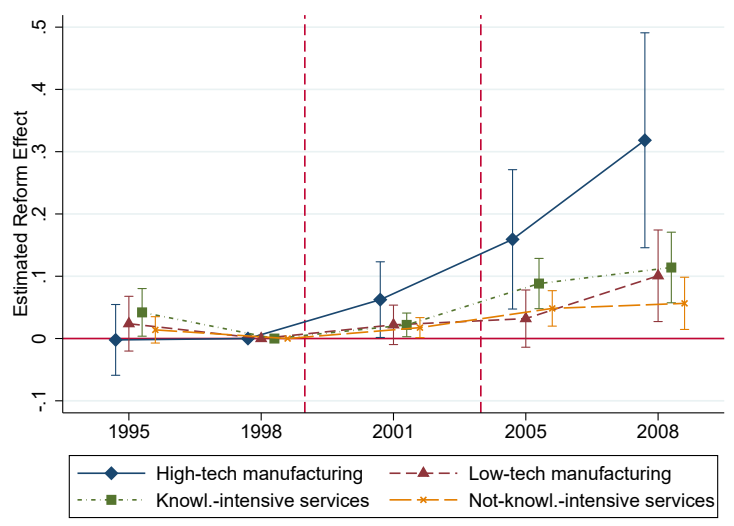

C. FTE employment of natives relative to FTE employment in 1998

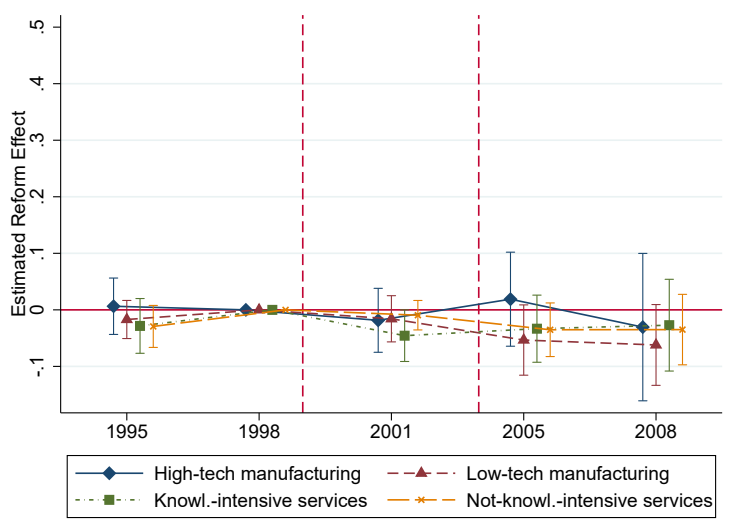

Notes: The figure estimates the effect of the free movement policy on FTE employment of incumbent establishments using private-sector establishment-level data from the BC. It plots event study coefficients and associated 95\% confidence intervals for highly treated establishments based on equation (2), estimated separately by establishments' broad sector of economic activity. The regressions control for establishment fixed effects, year fixed effects, and linear NUTS-II trends. The control group is establishments in the NBR. In panel A, the dependent variable is log FTE employment. In panel B, it is FTE employment of foreigners as a share of total employment in 1998. In panel C, it is FTE employment of Swiss nationals as a share of total employment in 1998. The samples cover the 1995-2008 period because the BC in 1991 and 2011 do not contain information on workers' nationality. All regressions are weighted using average establishment size (in FTE). Standard errors are clustered by commuting zone. Figure A.3 provides the same regressions for an approximate log outcome. 
Figure A.3: Effect of free movement policy on FTE employment by nationality (inverse hyperbolic sine)

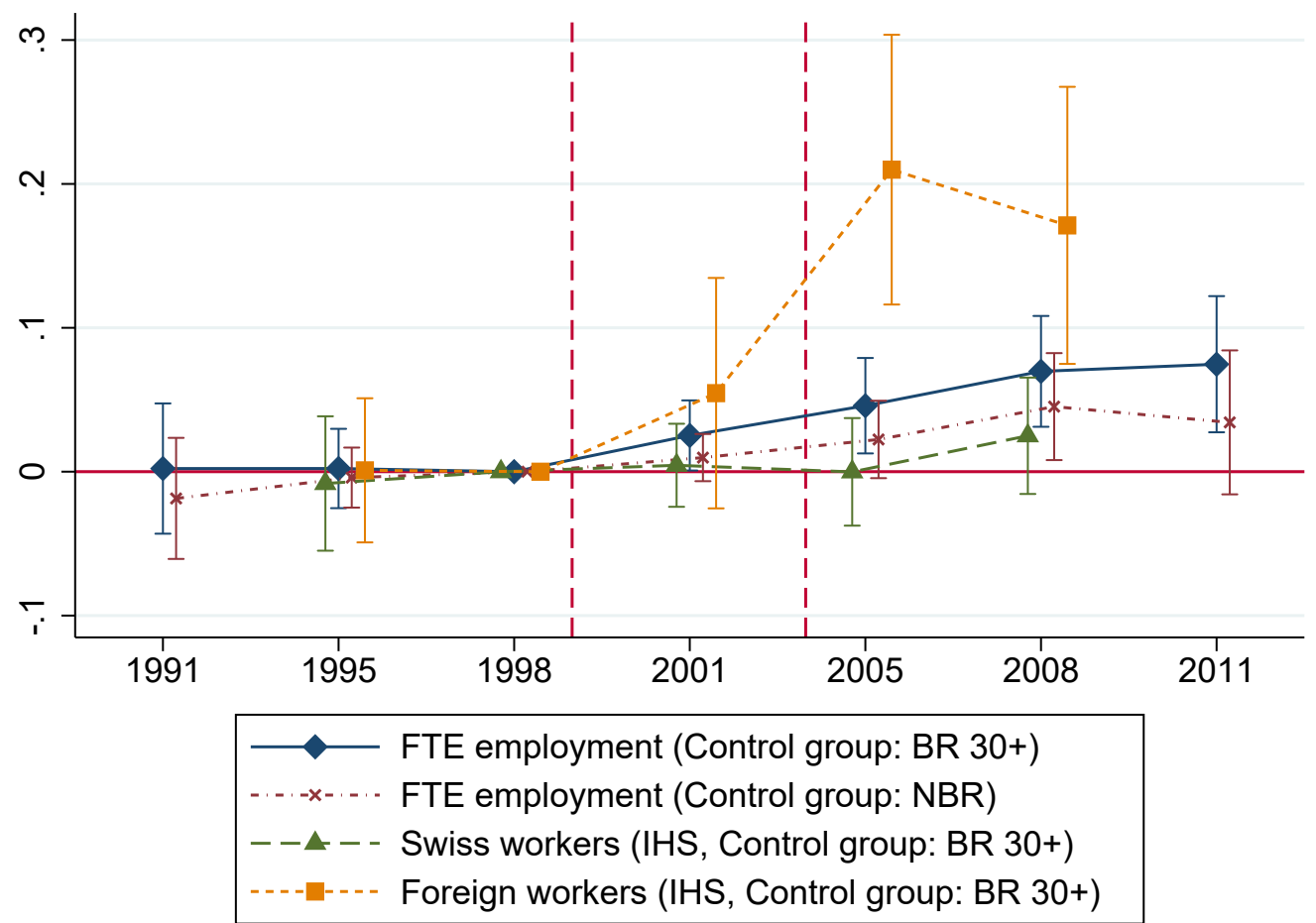

Notes: The figure plots the sequence of effects, and associated $95 \%$ confidence intervals, of the free movement policy on FTE employment of highly treated private-sector firms. The event studies are based on separate regressions of our main regression model using one of the two control groups (municipalities in the BR located more than 30 travel minutes to the border and municipalities in the NBR). The regressions are based on establishment-level data from the BC $1991-2011$. The dependent variables are log total FTE employment and the inverse hyperbolic sine (IHS) of establishments' FTE employment of Swiss and foreign nationals. The IHS of outcome $y$ is $\operatorname{IHS}(y)=\ln \left(y+\sqrt{1+y^{2}}\right)$. The IHS approximates the log of an outcome but has the advantage that it is defined at 0. All regressions control for establishment fixed effects, year fixed effects, and NUTS-II trends. The regressions are weighted using average establishment size (in FTE) as weight. Standard errors are clustered by commuting zone. 
Figure A.4: Effect of free movement policy by firms' pre-reform export share

(a) All private sector firms

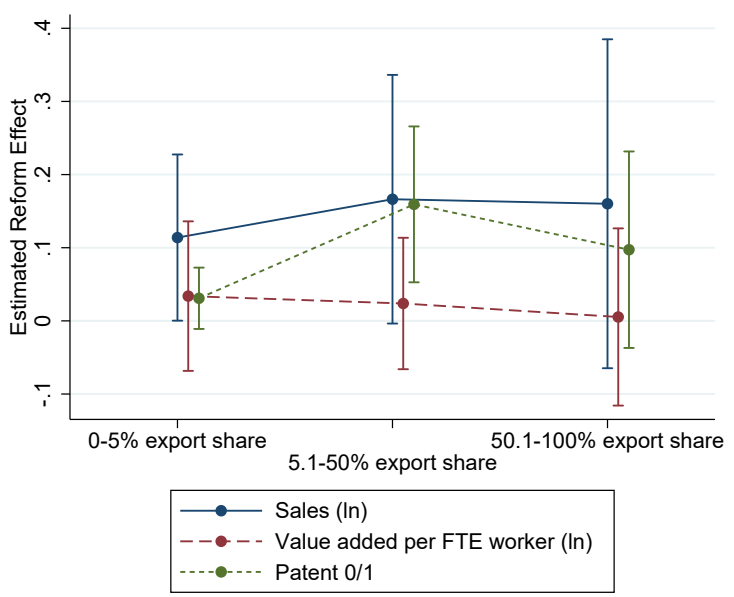

(b) Manufacturing only

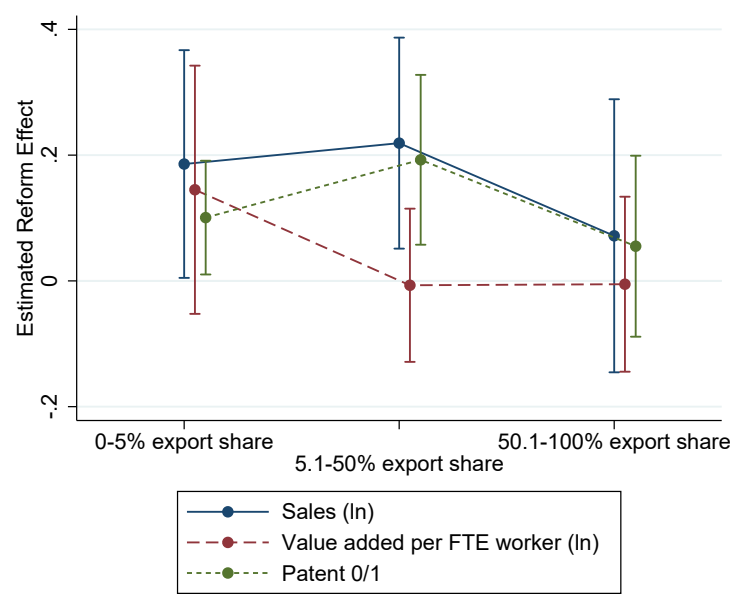

Notes: The figure studies whether the effects of the free movement policy depend on firms' export status. The coefficients are estimated using a version of our baseline regression model (equation (1)) augmented with interactions between our main treatment indicators (i.e. Freet $\left.\times I\left(d_{i}<15\right)\right)$ and indicator variables for the respective export shares. The regressions are based on firm-level data from the IS 1996-2013. We control for firm fixed effects, year fixed effects, and NUTS-II trends. The sample is restricted to the BR. The dependent variables are firms' log total sales, log value added per FTE worker, and the probability to file a patent application in the three years before the survey. Panel A uses our baseline firm sample in the IS. Panel B is restricted to manufacturing. Standard errors are clustered by commuting zone. The two subfigures show that the estimated reform effects are similar between firms with different initial export share. The exception is the patenting effect that is driven by firms with intermediate export share. This, however, results from the fact that the patenting effect is concentrated in manufacturing firms, which in Switzerland are more likely to export than the rest of the firms. If we focus on the manufacturing sector only, the patenting effect has no obvious relationship to firms' export status (panel B). 


\section{E Appendix tables}

Table A.2: Cross-border workers residing in Switzerland and abroad

\begin{tabular}{|c|c|c|c|c|c|c|}
\hline & \multicolumn{5}{|c|}{ 3-Years Average, in Thousands } & \multirow{2}{*}{$\begin{array}{r}\text { Average } \\
\text { Annual } \\
\text { Change }\end{array}$} \\
\hline & $\begin{array}{c}1999- \\
2001\end{array}$ & $\begin{array}{l}2002- \\
2004\end{array}$ & $\begin{array}{l}2005- \\
2007\end{array}$ & $\begin{array}{l}2008- \\
2010\end{array}$ & $\begin{array}{c}2011- \\
2013\end{array}$ & \\
\hline $\begin{array}{l}\text { Swiss border workers working } \\
\text { in Switzerland and living abroad }\end{array}$ & NA & NA & 10 & 8 & 15 & 0.63 \\
\hline $\begin{array}{l}\text { Foreign border workers working } \\
\text { in Switzerland and living abroad }\end{array}$ & 144 & 167 & 188 & 221 & 261 & 7.81 \\
\hline $\begin{array}{l}\text { Swiss border workers working } \\
\text { abroad and living in Switzerland }\end{array}$ & NA & 6 & 9 & 9 & 10 & 0.4 \\
\hline $\begin{array}{l}\text { Foreign border workers working } \\
\text { abroad and living in Switzerland }\end{array}$ & NA & 5 & 7 & 10 & 13 & 0.7 \\
\hline
\end{tabular}

Notes: This table provides data on the number of CBW on both sides of the Swiss border. In the three-year period from 2002 to 2004, 11,000 CBW living in Switzerland worked in neighboring countries. In the threeyear period 2011-2013, the number had increased to 23,000 (+12,000). There were approximately 100,000 additional CBW working in Switzerland but living in neighboring countries in the same period. Source: Swiss Federal Statistical Office. 
Table A.3: Characteristics of natives and cross-border workers in the border region, 1998 and 2010

\begin{tabular}{|c|c|c|c|c|c|c|}
\hline \multirow[b]{2}{*}{ Panel A: Worker characteristics } & \multicolumn{2}{|c|}{ Native workers } & \multicolumn{2}{|c|}{ Cross-border workers } & \multicolumn{2}{|c|}{ Resident immigrants } \\
\hline & 1998 & $\begin{array}{c}\Delta 2010 \\
-1998 \\
\end{array}$ & 1998 & $\begin{array}{c}\Delta 2010 \\
-1998 \\
\end{array}$ & 1998 & $\begin{array}{c}\Delta 2010 \\
-1998 \\
\end{array}$ \\
\hline \multicolumn{7}{|l|}{ Demographic characteristics } \\
\hline Share highly educated & 0.200 & 0.062 & 0.153 & 0.126 & 0.185 & 0.152 \\
\hline Share lower educated & 0.800 & -0.062 & 0.847 & -0.126 & 0.815 & -0.152 \\
\hline Mean age & 39.70 & 1.50 & 39.70 & 0.80 & 33.70 & 1.70 \\
\hline Share male & 0.598 & -0.054 & 0.693 & -0.033 & 0.665 & -0.067 \\
\hline Mean tenure & 9.30 & -1.10 & 9.50 & -2.30 & 4.20 & -1.30 \\
\hline Mean log hourly real wage & 3.566 & 0.032 & 3.455 & 0.079 & 3.305 & 0.182 \\
\hline \multicolumn{7}{|l|}{ Management positions } \\
\hline Share top management & 0.066 & 0.009 & 0.019 & 0.009 & 0.033 & 0.003 \\
\hline Share middle management & 0.088 & -0.004 & 0.052 & 0.011 & 0.051 & 0.023 \\
\hline Share lower management & 0.238 & -0.033 & 0.189 & 0.026 & 0.141 & 0.036 \\
\hline Share no management & 0.608 & 0.028 & 0.739 & -0.045 & 0.775 & -0.062 \\
\hline \multicolumn{7}{|l|}{ Occupation groups } \\
\hline Share high-paying occupations & 0.242 & 0.025 & 0.159 & 0.074 & 0.137 & 0.113 \\
\hline Share middle-paying occupations & 0.394 & -0.029 & 0.244 & 0.015 & 0.167 & 0.047 \\
\hline Share low-paying occupations & 0.364 & 0.004 & 0.597 & -0.089 & 0.697 & -0.160 \\
\hline \multicolumn{7}{|l|}{ Industries } \\
\hline Agriculture/Fishing/Mining & 0.004 & 0.002 & 0.005 & 0.001 & 0.005 & 0.001 \\
\hline Manufacturing & 0.265 & -0.060 & 0.461 & -0.081 & 0.226 & -0.053 \\
\hline Utilities & 0.007 & 0.001 & 0.001 & 0.002 & 0.001 & 0.001 \\
\hline Construction & 0.068 & 0.001 & 0.127 & -0.019 & 0.161 & -0.054 \\
\hline Wholesale/Retail/Repair & 0.203 & 0.007 & 0.144 & 0.009 & 0.100 & 0.034 \\
\hline Hotels/Restaurants & 0.037 & 0.007 & 0.055 & -0.004 & 0.244 & -0.081 \\
\hline Transport/Communication/Storage & 0.062 & -0.014 & 0.064 & -0.010 & 0.038 & -0.006 \\
\hline Financial Intermediation & 0.107 & -0.020 & 0.021 & 0.003 & 0.037 & 0.011 \\
\hline Real Estate/R\&D/IT/Business activities & 0.113 & 0.028 & 0.056 & 0.066 & 0.077 & 0.130 \\
\hline Education & 0.022 & 0.001 & 0.007 & 0.007 & 0.015 & 0.009 \\
\hline Health & 0.083 & 0.035 & 0.042 & 0.019 & 0.065 & 0.001 \\
\hline Personal Services & 0.029 & 0.012 & 0.016 & 0.008 & 0.031 & 0.006 \\
\hline No. Workers & $1,023,236$ & 233,750 & 103,863 & 71,343 & 81,050 & 85,971 \\
\hline \multicolumn{7}{|c|}{ Panel B: Relative wage gap natives vs. cross-border workers (2004-2010) } \\
\hline \multicolumn{5}{|c|}{$\begin{array}{l}\text { (i) Municipality and year fixed effects } \\
\text { (ii) Year } \times \text { establishment } \times \text { occupation fixed effects } \\
\text { (iii) Year } \times \text { establishment } \times \text { occupation } \times \text { tenure fixed effects }\end{array}$} & $\begin{array}{l}\text { Coeff. } \\
-0.055 \\
-0.031 \\
-0.015\end{array}$ & $\begin{array}{c}\text { S.E. } \\
(0.001) \\
(0.001) \\
(0.001)\end{array}$ \\
\hline
\end{tabular}

Notes: This table shows descriptive statistics of native workers, cross-border workers and resident immigrants in 1998 and their change between 1998 and 2010. In Panel A, occupations are categorized into high-, middle- and low-paying occupations according the mean wage in 1998 (see Table A.4). Panel B reports the main coefficient of individual-level (Mincer) regressions of the log hourly wage on a dummy for cross-border workers. The sample includes natives and CBW only and is based on the years 2004-2010. All regressions control for age, age squared, marital status, sex and three education groups (tertiary, secondary, primary or less). Row (i) additionally includes municipality and year fixed effects. Row (ii) further adds year-specific establishment fixed effects interacted with fixed effects for 24 occupations in the SESS. Row (iii) also adds interactions with tenure. The table is based on sample restrictions outlined in 3.1 . This is the reason why the number of CBW reported in this table deviates from the numbers on CBW reported in section 2 . SESS data. 
Table A.4: Effect on share of total immigrants in occupation groups relative to total employment in 1998

Dependent variable: number of total immigrants in occupation relative to total employment in 1998

\begin{tabular}{|c|c|c|c|c|c|c|c|c|}
\hline & $(1)$ & $(2)$ & $(3)$ & $(4)$ & $(5)$ & $(6)$ & $(7)$ & $(8)$ \\
\hline \multicolumn{9}{|c|}{ A. High-paying occupations } \\
\hline & $\begin{array}{l}\text { Define goal } \\
\text { \& strategy } \\
\text { in firms }\end{array}$ & $\begin{array}{c}\text { Logistics, } \\
\text { strategy } \\
\text { department }\end{array}$ & $\begin{array}{l}\text { Review, } \\
\text { consult, } \\
\text { certify }\end{array}$ & Invest & $\mathrm{R} \& \mathrm{D}$ & $\begin{array}{l}\text { Analyse, } \\
\text { program, } \\
\text { operating }\end{array}$ & $\begin{array}{l}\text { Plan, } \\
\text { Design }\end{array}$ & $\begin{array}{l}\text { Edu- } \\
\text { cation }\end{array}$ \\
\hline $\begin{array}{l}\text { Freet }_{t} \cdot I\left(d_{m} \leq 15\right) \\
\text { Free }_{t} \cdot I\left(15<d_{m} \leq 30\right)\end{array}$ & $\begin{array}{c}0.004^{* * *} \\
(0.001) \\
0.000 \\
(0.000)\end{array}$ & $\begin{array}{c}0.002^{* * *} \\
(0.000) \\
0.000^{*} \\
(0.000)\end{array}$ & $\begin{array}{l}0.009^{* * *} \\
(0.002) \\
0.002^{*} \\
(0.001)\end{array}$ & $\begin{array}{c}0.002^{* * *} \\
(0.001) \\
-0.000 \\
(0.000)\end{array}$ & $\begin{array}{c}0.006^{* *} \\
(0.002) \\
0.000 \\
(0.001)\end{array}$ & $\begin{array}{c}0.004^{* * *} \\
(0.001) \\
0.001^{* *} \\
(0.001)\end{array}$ & $\begin{array}{c}0.001^{*} \\
(0.001) \\
0.001^{* *} \\
(0.001)\end{array}$ & $\begin{array}{c}0.003^{* * *} \\
(0.001) \\
0.000 \\
(0.001)\end{array}$ \\
\hline Change within occ. $(\mathrm{BR} \leq 15 \mathrm{~min})$ & 0.135 & 0.102 & 0.204 & 0.119 & 0.345 & 0.169 & 0.037 & 0.121 \\
\hline \multicolumn{9}{|c|}{ B. Middle-paying occupations } \\
\hline & $\begin{array}{l}\text { Machine } \\
\text { Operators }\end{array}$ & $\begin{array}{c}\text { Ac- } \\
\text { counting, } \\
\text { HR }\end{array}$ & Clerks & $\begin{array}{l}\text { Other } \\
\text { clerical } \\
\text { occ. }\end{array}$ & Security & $\begin{array}{c}\text { Medical, } \\
\text { nursing, } \\
\text { social tasks }\end{array}$ & $\begin{array}{c}\text { Cultural, } \\
\text { Entertain., } \\
\text { Info., Sport }\end{array}$ & Other \\
\hline $\begin{array}{l}\text { Freet }_{t} \cdot I\left(d_{m} \leq 15\right) \\
\text { Free }_{t} \cdot I\left(15<d_{m} \leq 30\right)\end{array}$ & $\begin{array}{c}0.005^{* * *} \\
(0.002) \\
0.002^{* *} \\
(0.001)\end{array}$ & $\begin{array}{c}0.004^{* * *} \\
(0.001) \\
0.001^{* * *} \\
(0.000)\end{array}$ & $\begin{array}{c}0.002^{* * *} \\
(0.001) \\
0.001^{* * *} \\
(0.000)\end{array}$ & $\begin{array}{c}0.005^{* * *} \\
(0.001) \\
0.001^{*} \\
(0.001)\end{array}$ & $\begin{array}{c}0.001^{* * *} \\
(0.000) \\
0.000^{*} \\
(0.000)\end{array}$ & $\begin{array}{c}0.004^{* * *} \\
(0.001) \\
0.001 \\
(0.001)\end{array}$ & $\begin{array}{l}0.001^{*} \\
(0.000) \\
-0.000 \\
(0.000)\end{array}$ & $\begin{array}{c}-0.008^{* *} \\
(0.003) \\
0.001 \\
(0.001)\end{array}$ \\
\hline Change within occ. $(\mathrm{BR} \leq 15 \mathrm{~min})$ & 0.079 & 0.078 & 0.038 & 0.074 & 0.141 & 0.081 & 0.077 & -0.204 \\
\hline \multicolumn{9}{|c|}{ C. Low-paying occupations } \\
\hline & $\begin{array}{l}\text { Manufac- } \\
\text { turing }\end{array}$ & $\begin{array}{l}\text { Con- } \\
\text { struction }\end{array}$ & Craft & Retail & Transport & $\begin{array}{l}\text { Manicure, } \\
\text { laundry }\end{array}$ & Cleaning & $\begin{array}{c}\text { Re- } \\
\text { stauration }\end{array}$ \\
\hline $\begin{array}{l}\text { Free }_{t} \cdot I\left(d_{m} \leq 15\right) \\
\text { Free }_{t} \cdot I\left(15<d_{m} \leq 30\right)\end{array}$ & $\begin{array}{c}0.002 \\
(0.005) \\
0.003 \\
(0.003)\end{array}$ & $\begin{array}{c}0.000 \\
(0.003) \\
0.000 \\
(0.003)\end{array}$ & $\begin{array}{l}0.000 \\
(0.000) \\
-0.000 \\
(0.001)\end{array}$ & $\begin{array}{c}0.003^{* * *} \\
(0.001) \\
0.003^{* * *} \\
(0.001)\end{array}$ & $\begin{array}{c}0.001 \\
(0.001) \\
0.001 \\
(0.001)\end{array}$ & $\begin{array}{c}0.001^{* * *} \\
(0.000) \\
0.000 \\
(0.000)\end{array}$ & $\begin{array}{c}0.002^{*} \\
(0.001) \\
0.001 \\
(0.001)\end{array}$ & $\begin{array}{c}0.002 \\
(0.004) \\
-0.000 \\
(0.004)\end{array}$ \\
\hline Change within occ. $(\mathrm{BR} \leq 15 \mathrm{~min})$ & 0.014 & 0.003 & 0.296 & 0.042 & 0.021 & 0.139 & 0.101 & 0.027 \\
\hline Observations & 9585 & 9585 & 9585 & 9585 & 9585 & 9585 & 9585 & 9585 \\
\hline $\begin{array}{l}\text { Year/Area fixed effects } \\
\text { Nuts-II trends }\end{array}$ & $\sqrt{ }$ & $\sqrt{ }$ & $\sqrt{ }$ & $\sqrt{ }$ & $\sqrt{ }$ & $\sqrt{ }$ & $\sqrt{ }$ & $\sqrt{ }$ \\
\hline
\end{tabular}

Notes: This table shows the effect of the free movement policy on the number of immigrants in an occupation standardized by total local employment in 1998 based on regression specification (1). Municipalities in the BR 30+ constitute the control group. The total number of immigrants is split into 24 mutually exclusive and exhaustive occupations categories available in the SESS. Workers with missing occupation information are allocated to the category "other occupations". Occupations are categorized into the high-, middle- and low-paying according the mean wage in 1998 . The last row in each panel indicates the change in the number of immigrants in an occupation relative to the total number of workers in that occupation in $1998, \widetilde{\delta^{o}}$. To this end, the coefficient $\delta^{o} \equiv F_{r e e_{t}} \cdot\left(d_{i} \leq 15\right)$ is scaled with $\widetilde{\delta^{o}}=\delta^{o} \times\left(\overline{E m p_{i, 1998}} / \overline{E m p_{i, 1998}^{o}}\right)$ where $\overline{E m p_{i, 1998}}$ is the average total employment and $\overline{E m p_{i, 1998}^{o}}$ is the average occupation group specific employment, both in municipalities in the border region in 1998. Free $t$ is one from year 2004 onward. The coefficients for the transition phase are included but not shown for brevity. $\left(d_{i} \leq x\right)$ and $\left(y<d_{i} \leq z\right)$ indicate whether a municipality is located less than $x$ travel minutes or between $y$ and $z$ travel minutes from the next border crossing, respectively. Regressions are weighted using the total number of workers in 1998. Robust standard errors, clustered by commuting zone, are given in parentheses. $* * *, * *, *$, denote statistical significance at the $1 \%, 5 \%$ and $10 \%$ level, respectively. SESS data. 
Table A.5: Effect of free movement policy on wages and employment of natives by education group

\begin{tabular}{|c|c|c|c|c|c|c|}
\hline \multirow[t]{3}{*}{$\overline{\text { Dependent variable }}$} & \multicolumn{3}{|c|}{$\begin{array}{l}\text { Mean log hourly wages } \\
\text { by education group }\end{array}$} & \multicolumn{3}{|c|}{$\begin{array}{l}\text { Log full-time equivalents } \\
\text { by education group }\end{array}$} \\
\hline & all & high & lower & all & high & lower \\
\hline & (1) & $(2)$ & $(3)$ & (4) & $(5)$ & (6) \\
\hline \multicolumn{7}{|c|}{ A. Baseline: Control group BR 30+ } \\
\hline Transition $_{t} \cdot I\left(d_{m} \leq 15\right)$ & $\begin{array}{c}0.014 \\
(0.010)\end{array}$ & $\begin{array}{l}0.028^{* *} \\
(0.014)\end{array}$ & $\begin{array}{l}-0.000 \\
(0.010)\end{array}$ & $\begin{array}{c}0.008 \\
(0.057)\end{array}$ & $\begin{array}{l}0.132^{*} \\
(0.075)\end{array}$ & $\begin{array}{l}-0.028 \\
(0.056)\end{array}$ \\
\hline Transition $_{t} \cdot I\left(15<d_{m} \leq 30\right)$ & $\begin{array}{l}0.019^{* *} \\
(0.009)\end{array}$ & $\begin{array}{c}0.020 \\
(0.014)\end{array}$ & $\begin{array}{c}0.008 \\
(0.009)\end{array}$ & $\begin{array}{c}0.032 \\
(0.046)\end{array}$ & $\begin{array}{l}0.122^{*} \\
(0.067)\end{array}$ & $\begin{array}{c}0.008 \\
(0.048)\end{array}$ \\
\hline Free $_{t} \cdot I\left(d_{m} \leq 15\right)$ & $\begin{array}{l}-0.002 \\
(0.021)\end{array}$ & $\begin{array}{c}0.045^{* * *} \\
(0.015)\end{array}$ & $\begin{array}{l}-0.022 \\
(0.022)\end{array}$ & $\begin{array}{c}0.040 \\
(0.045)\end{array}$ & $\begin{array}{c}0.163^{* *} \\
(0.064)\end{array}$ & $\begin{array}{l}-0.003 \\
(0.051)\end{array}$ \\
\hline Free $_{t} \cdot I\left(15<d_{m} \leq 30\right)$ & $\begin{array}{c}0.009 \\
(0.006)\end{array}$ & $\begin{array}{c}0.015 \\
(0.012)\end{array}$ & $\begin{array}{l}-0.006 \\
(0.007)\end{array}$ & $\begin{array}{c}0.059 \\
(0.039)\end{array}$ & $\begin{array}{c}0.193^{* * *} \\
(0.072)\end{array}$ & $\begin{array}{c}0.014 \\
(0.044)\end{array}$ \\
\hline Observations & 11181 & 8383 & 11045 & 11188 & 8415 & 11049 \\
\hline \multicolumn{7}{|c|}{ B. Control group: NBR } \\
\hline Transition $_{t} \cdot I\left(d_{m} \leq 15\right)$ & $\begin{array}{c}0.001 \\
(0.009)\end{array}$ & $\begin{array}{l}0.023^{* *} \\
(0.010)\end{array}$ & $\begin{array}{l}-0.007 \\
(0.008)\end{array}$ & $\begin{array}{l}-0.051 \\
(0.056)\end{array}$ & $\begin{array}{c}0.027 \\
(0.073)\end{array}$ & $\begin{array}{l}-0.074 \\
(0.058)\end{array}$ \\
\hline Transition $_{t} \cdot I\left(15<d_{m} \leq 30\right)$ & $\begin{array}{c}0.007 \\
(0.009)\end{array}$ & $\begin{array}{c}0.017 \\
(0.011)\end{array}$ & $\begin{array}{c}0.002 \\
(0.007)\end{array}$ & $\begin{array}{l}-0.017 \\
(0.041)\end{array}$ & $\begin{array}{c}0.013 \\
(0.048)\end{array}$ & $\begin{array}{l}-0.025 \\
(0.047)\end{array}$ \\
\hline Free $_{t} \cdot I\left(d_{m} \leq 15\right)$ & $\begin{array}{l}-0.005 \\
(0.020)\end{array}$ & $\begin{array}{c}0.043^{* * *} \\
(0.013)\end{array}$ & $\begin{array}{l}-0.021 \\
(0.021)\end{array}$ & $\begin{array}{l}-0.055 \\
(0.043)\end{array}$ & $\begin{array}{c}0.039 \\
(0.060)\end{array}$ & $\begin{array}{l}-0.088^{*} \\
(0.047)\end{array}$ \\
\hline Free $_{t} \cdot I\left(15<d_{m} \leq 30\right)$ & $\begin{array}{c}0.006 \\
(0.008)\end{array}$ & $\begin{array}{l}0.018^{*} \\
(0.010)\end{array}$ & $\begin{array}{l}-0.003 \\
(0.009)\end{array}$ & $\begin{array}{l}-0.018 \\
(0.034)\end{array}$ & $\begin{array}{c}0.062 \\
(0.050)\end{array}$ & $\begin{array}{l}-0.048 \\
(0.034)\end{array}$ \\
\hline Observations & 14640 & 10917 & 14447 & 14649 & 10951 & 14451 \\
\hline $\begin{array}{l}\text { Year/Area fixed effects } \\
\text { Nuts-II trends }\end{array}$ & $\begin{array}{l}\sqrt{ } \\
\sqrt{ }\end{array}$ & $\begin{array}{l}\sqrt{ } \\
\sqrt{ }\end{array}$ & $\begin{array}{l}\sqrt{ } \\
\sqrt{ }\end{array}$ & $\begin{array}{l}\sqrt{ } \\
\sqrt{ }\end{array}$ & $\begin{array}{l}\sqrt{ } \\
\sqrt{ }\end{array}$ & $\begin{array}{l}\sqrt{ } \\
\sqrt{ }\end{array}$ \\
\hline
\end{tabular}

Notes: This table shows the baseline effect of the free movement policy on wages and employment of natives by education group based on regression specification (1). In column 1-3, the dependent variable is the mean log hourly real wage by education group. The dependent variable in column 4-6 is the log number of native full-time equivalents worked by natives by education group. In panel A (panel B), municipalities in the BR 30+ (the NBR) constitute the control group. Transition $_{t}$ is one for the period between 2000 and 2003, whereas Free $t$ is one from year 2004 onward. $\left(d_{i} \leq x\right)$ and $\left(y<d_{i}<z\right)$ indicate whether a municipality is located less than $x$ travel minutes or between $y$ and $z$ travel minutes from the next border crossing, respectively. Regressions are weighted using the total number of natives in a cell. Robust standard errors, clustered by commuting zone, are given in parentheses. ${ }^{* * *},{ }^{* *},{ }^{*}$, denote statistical significance at the $1 \%, 5 \%$ and $10 \%$ level, respectively. SESS data. 
Table A.6: Main robustness checks for labor market analysis

\begin{tabular}{|c|c|c|c|c|c|c|c|}
\hline \multirow[t]{3}{*}{ Dependent variable } & \multirow{3}{*}{$\begin{array}{c}\begin{array}{c}\text { Immi- } \\
\text { grants }\end{array} \\
\text { Emp '98 } \\
(1)\end{array}$} & \multicolumn{3}{|c|}{$\begin{array}{l}\text { Mean log hourly wages } \\
\text { by education group }\end{array}$} & \multicolumn{3}{|c|}{$\begin{array}{l}\text { Log full-time equivalents } \\
\text { by education group }\end{array}$} \\
\hline & & all & high & lower & all & high & lower \\
\hline & & $(2)$ & $(3)$ & $(4)$ & $(5)$ & $(6)$ & $(7)$ \\
\hline \multicolumn{8}{|c|}{ A. Baseline with Nuts II trends } \\
\hline Free $_{t} \cdot I\left(d_{m} \leq 15\right)$ & $\begin{array}{c}0.056^{* * *} \\
(0.014)\end{array}$ & $\begin{array}{l}-0.002 \\
(0.021)\end{array}$ & $\begin{array}{c}0.045^{* * *} \\
(0.015)\end{array}$ & $\begin{array}{l}-0.022 \\
(0.022)\end{array}$ & $\begin{array}{c}0.040 \\
(0.045)\end{array}$ & $\begin{array}{c}0.163^{* *} \\
(0.064)\end{array}$ & $\begin{array}{l}-0.003 \\
(0.051)\end{array}$ \\
\hline Freet $_{t} \cdot I\left(15<d_{m} \leq 30\right)$ & $\begin{array}{l}0.022^{* * *} \\
(0.008)\end{array}$ & $\begin{array}{c}0.009 \\
(0.006)\end{array}$ & $\begin{array}{c}0.015 \\
(0.012)\end{array}$ & $\begin{array}{l}-0.006 \\
(0.007)\end{array}$ & $\begin{array}{c}0.059 \\
(0.039)\end{array}$ & $\begin{array}{c}0.193^{* * *} \\
(0.072)\end{array}$ & $\begin{array}{c}0.014 \\
(0.044)\end{array}$ \\
\hline Observations & 9585 & 11181 & 8383 & 11045 & 11188 & 8415 & 11049 \\
\hline \multicolumn{8}{|c|}{ B. Including Bartik } \\
\hline Free $_{t} \cdot I\left(d_{m} \leq 15\right)$ & $\begin{array}{c}0.056^{* * *} \\
(0.014)\end{array}$ & $\begin{array}{c}0.006 \\
(0.017)\end{array}$ & $\begin{array}{c}0.045^{* * *} \\
(0.015)\end{array}$ & $\begin{array}{l}-0.017 \\
(0.019)\end{array}$ & $\begin{array}{c}0.041 \\
(0.046)\end{array}$ & $\begin{array}{c}0.163^{* *} \\
(0.063)\end{array}$ & $\begin{array}{l}-0.006 \\
(0.053)\end{array}$ \\
\hline Free $_{t} \cdot I\left(15<d_{m} \leq 30\right)$ & $\begin{array}{l}0.022^{* * *} \\
(0.008)\end{array}$ & $\begin{array}{l}0.014^{*} \\
(0.008)\end{array}$ & $\begin{array}{c}0.016 \\
(0.012)\end{array}$ & $\begin{array}{l}-0.001 \\
(0.007)\end{array}$ & $\begin{array}{c}0.059 \\
(0.038)\end{array}$ & $\begin{array}{l}0.193^{* *} \\
(0.073)\end{array}$ & $\begin{array}{c}0.011 \\
(0.043)\end{array}$ \\
\hline Observations & 9585 & 11181 & 8383 & 11045 & 11188 & 8415 & 11049 \\
\hline \multicolumn{8}{|c|}{ C. Nuts II regions $\mathrm{X}$ year fixed effects } \\
\hline Free $_{t} \cdot I\left(d_{m} \leq 15\right)$ & $\begin{array}{c}0.060^{* * *} \\
(0.014)\end{array}$ & $\begin{array}{c}0.001 \\
(0.020)\end{array}$ & $\begin{array}{c}0.048^{* * *} \\
(0.014)\end{array}$ & $\begin{array}{l}-0.020 \\
(0.021)\end{array}$ & $\begin{array}{c}0.037 \\
(0.047)\end{array}$ & $\begin{array}{c}0.172^{* *} \\
(0.066)\end{array}$ & $\begin{array}{l}-0.008 \\
(0.053)\end{array}$ \\
\hline Free $_{t} \cdot I\left(15<d_{m} \leq 30\right)$ & $\begin{array}{l}0.022^{* * *} \\
(0.008)\end{array}$ & $\begin{array}{l}0.008 \\
(0.007)\end{array}$ & $\begin{array}{c}0.015 \\
(0.013)\end{array}$ & $\begin{array}{l}-0.006 \\
(0.007)\end{array}$ & $\begin{array}{c}0.059 \\
(0.039)\end{array}$ & $\begin{array}{c}0.186^{* *} \\
(0.075)\end{array}$ & $\begin{array}{c}0.015 \\
(0.044)\end{array}$ \\
\hline Observations & 9585 & 11181 & 8383 & 11045 & 11188 & 8415 & 11049 \\
\hline \multicolumn{8}{|c|}{ D. Baseline omitting nuts II trends } \\
\hline Free $_{t} \cdot I\left(d_{m} \leq 15\right)$ & $\begin{array}{c}0.064^{* * *} \\
(0.023)\end{array}$ & $\begin{array}{l}-0.017 \\
(0.036)\end{array}$ & $\begin{array}{c}0.027 \\
(0.023)\end{array}$ & $\begin{array}{l}-0.033 \\
(0.035)\end{array}$ & $\begin{array}{c}0.051 \\
(0.051)\end{array}$ & $\begin{array}{c}0.143^{* *} \\
(0.070)\end{array}$ & $\begin{array}{c}0.023 \\
(0.067)\end{array}$ \\
\hline Free $_{t} \cdot I\left(15<d_{m} \leq 30\right)$ & $\begin{array}{c}0.021^{* *} \\
(0.011)\end{array}$ & $\begin{array}{l}-0.000 \\
(0.006)\end{array}$ & $\begin{array}{c}0.012 \\
(0.013)\end{array}$ & $\begin{array}{c}-0.016^{* *} \\
(0.008)\end{array}$ & $\begin{array}{l}0.080^{*} \\
(0.042)\end{array}$ & $\begin{array}{c}0.217^{* * *} \\
(0.076)\end{array}$ & $\begin{array}{c}0.033 \\
(0.050)\end{array}$ \\
\hline
\end{tabular}

E. Baseline excluding industries exposed to bilateral agreements on trade

\begin{tabular}{lccccccc} 
Free $_{t} \cdot I\left(d_{m} \leq 15\right)$ & $0.044^{* * *}$ & -0.001 & $0.051^{* * *}$ & -0.021 & $0.144^{*}$ & $0.272^{* * *}$ & 0.107 \\
& $(0.015)$ & $(0.020)$ & $(0.013)$ & $(0.019)$ & $(0.084)$ & $(0.089)$ & $(0.100)$ \\
Free $_{t} \cdot I\left(15<d_{m} \leq 30\right)$ & 0.020 & $0.017^{*}$ & 0.020 & -0.003 & $0.105^{* *}$ & $0.315^{* * *}$ & 0.048 \\
& $(0.013)$ & $(0.009)$ & $(0.013)$ & $(0.010)$ & $(0.047)$ & $(0.084)$ & $(0.051)$ \\
Observations & 8802 & 10308 & 6896 & 10138 & 10315 & 6928 & 10140 \\
\hline Year/Area fixed effects & $\sqrt{ }$ & $\sqrt{ }$ & $\sqrt{ }$ & $\sqrt{ }$ & $\sqrt{ }$ & $\sqrt{ }$ & $\sqrt{ }$ \\
\hline \hline
\end{tabular}

Notes: This table documents the robustness the reform effect on wages and employment of natives by education group based on regression specification (1). In column 1, the dependent variable is the total number of immigrants standardized by total employment in 1998. In column $2-4$, the dependent variable is the mean log hourly real wage by education group. The dependent variable in column 5-7 is the log number of native full-time equivalents worked by natives by education group. Panel A repeats estimates from the baseline specification as in Table A.5 including Nuts-II regional trends. Panel $\mathrm{B}$ adds the Bartik measure, computed separately for wages (Column 2-4) and full-time equivalents (Column 1, 5-7) by education group, as control for sector-driven trends as specified in Appendix B.3. Panel C instead includes full interactions of fixed effects at the level of Nuts-II regions and years instead of regional trends. In Panel D NUTS-II trends are omitted. Panel E uses the baseline specification and the sample includes only two-digit industries that are unaffected by the bilateral agreements according to a classification by Bühler et al. (2011). Free $t$ is one for municipalities in the border region after 2004. $\left(d_{i} \leq x\right)$ and $\left(y<d_{i} \leq z\right)$ indicate whether a municipality is located less than $x$ travel minutes or between $y$ and $z$ travel minutes from the next border crossing, respectively. Distance interactions with the transition phase are omitted for brevity. Regressions are weighted using the total number of natives in a cell. Robust standard errors, clustered by commuting zone, are given in parentheses. ${ }^{* * *},{ }^{* *},{ }^{*}$, denote statistical significance at the $1 \%, 5 \%$ and $10 \%$ level, respectively. SESS data. 
Table A.7: Robustness of labor market outcomes to dropping cities

\begin{tabular}{|c|c|c|c|c|c|c|c|}
\hline \multirow[t]{3}{*}{ Dependent variable } & \multirow{3}{*}{$\begin{array}{c}\begin{array}{c}\text { Immi- } \\
\text { grants / }\end{array} \\
\text { Emp '98 } \\
(1)\end{array}$} & \multicolumn{3}{|c|}{$\begin{array}{l}\text { Mean log hourly wages } \\
\text { by education group }\end{array}$} & \multicolumn{3}{|c|}{$\begin{array}{c}\log \# \text { full-time equivalents } \\
\text { by education group }\end{array}$} \\
\hline & & all & high & lower & all & high & lower \\
\hline & & $(2)$ & (3) & (4) & $(5)$ & (6) & (7) \\
\hline \multicolumn{8}{|c|}{ A. Baseline } \\
\hline Free $_{t} \cdot I\left(d_{m} \leq 15\right)$ & $\begin{array}{c}0.056^{* * *} \\
(0.014)\end{array}$ & $\begin{array}{l}-0.002 \\
(0.021)\end{array}$ & $\begin{array}{c}0.045^{* * *} \\
(0.015)\end{array}$ & $\begin{array}{l}-0.022 \\
(0.022)\end{array}$ & $\begin{array}{c}0.040 \\
(0.045)\end{array}$ & $\begin{array}{c}0.163^{* *} \\
(0.064)\end{array}$ & $\begin{array}{l}-0.003 \\
(0.051)\end{array}$ \\
\hline Free $_{t} \cdot I\left(15<d_{m} \leq 30\right)$ & $\begin{array}{c}0.022^{* * *} \\
(0.008)\end{array}$ & $\begin{array}{c}0.009 \\
(0.006)\end{array}$ & $\begin{array}{c}0.015 \\
(0.012)\end{array}$ & $\begin{array}{l}-0.006 \\
(0.007)\end{array}$ & $\begin{array}{l}0.059 \\
(0.039)\end{array}$ & $\begin{array}{c}0.193^{* * *} \\
(0.072)\end{array}$ & $\begin{array}{r}0.014 \\
(0.044)\end{array}$ \\
\hline Observations & 9585 & 11181 & 8383 & 11045 & 11188 & 8415 & 11049 \\
\hline \multicolumn{8}{|c|}{ B. Dropping Geneva } \\
\hline Free $_{t} \cdot I\left(d_{m} \leq 15\right)$ & $\begin{array}{c}0.058^{* * *} \\
(0.018)\end{array}$ & $\begin{array}{l}-0.009 \\
(0.023)\end{array}$ & $\begin{array}{c}0.033^{* *} \\
(0.015)\end{array}$ & $\begin{array}{l}-0.024 \\
(0.024)\end{array}$ & $\begin{array}{l}0.036 \\
(0.049)\end{array}$ & $\begin{array}{c}0.139^{* *} \\
(0.067)\end{array}$ & $\begin{array}{c}0.005 \\
(0.055)\end{array}$ \\
\hline Free $_{t} \cdot I\left(15<d_{m} \leq 30\right)$ & $\begin{array}{c}0.023^{* * *} \\
(0.008)\end{array}$ & $\begin{array}{c}0.008 \\
(0.006)\end{array}$ & $\begin{array}{c}0.013 \\
(0.012)\end{array}$ & $\begin{array}{l}-0.006 \\
(0.007)\end{array}$ & $\begin{array}{c}0.059 \\
(0.039)\end{array}$ & $\begin{array}{c}0.193^{* * *} \\
(0.071)\end{array}$ & $\begin{array}{c}0.017 \\
(0.044)\end{array}$ \\
\hline Observations & 9576 & 11172 & 8374 & 11036 & 11179 & 8406 & 11040 \\
\hline \multicolumn{8}{|c|}{ C. Dropping Basel } \\
\hline Free $_{t} \cdot I\left(d_{m} \leq 15\right)$ & $\begin{array}{c}0.054^{* * *} \\
(0.016)\end{array}$ & $\begin{array}{c}0.024^{* * *} \\
(0.009)\end{array}$ & $\begin{array}{c}0.046^{* * *} \\
(0.016)\end{array}$ & $\begin{array}{c}0.006 \\
(0.008)\end{array}$ & $\begin{array}{c}0.003 \\
(0.042)\end{array}$ & $\begin{array}{c}0.157^{* *} \\
(0.063)\end{array}$ & $\begin{array}{l}-0.053 \\
(0.042)\end{array}$ \\
\hline Free $_{t} \cdot I\left(15<d_{m} \leq 30\right)$ & $\begin{array}{c}0.023^{* * *} \\
(0.008)\end{array}$ & $\begin{array}{l}0.006 \\
(0.005)\end{array}$ & $\begin{array}{c}0.015 \\
(0.012)\end{array}$ & $\begin{array}{l}-0.009 \\
(0.006)\end{array}$ & $\begin{array}{l}0.064 \\
(0.039)\end{array}$ & $\begin{array}{c}0.197^{* * *} \\
(0.072)\end{array}$ & $\begin{array}{c}0.020 \\
(0.044)\end{array}$ \\
\hline Observations & 9576 & 11172 & 8374 & 11036 & 11179 & 8406 & 11040 \\
\hline \multicolumn{8}{|c|}{ D. Dropping Lugano } \\
\hline Free $_{t} \cdot I\left(d_{m} \leq 15\right)$ & $\begin{array}{c}0.057^{* * *} \\
(0.014)\end{array}$ & $\begin{array}{l}-0.001 \\
(0.022)\end{array}$ & $\begin{array}{c}0.047^{* * *} \\
(0.015)\end{array}$ & $\begin{array}{l}-0.021 \\
(0.022)\end{array}$ & $\begin{array}{l}0.038 \\
(0.045)\end{array}$ & $\begin{array}{c}0.155^{* *} \\
(0.064)\end{array}$ & $\begin{array}{l}-0.003 \\
(0.052)\end{array}$ \\
\hline Free $_{t} \cdot I\left(15<d_{m} \leq 30\right)$ & $\begin{array}{c}0.022^{* * *} \\
(0.008)\end{array}$ & $\begin{array}{c}0.009 \\
(0.006)\end{array}$ & $\begin{array}{c}0.015 \\
(0.012)\end{array}$ & $\begin{array}{l}-0.006 \\
(0.007)\end{array}$ & $\begin{array}{l}0.059 \\
(0.039)\end{array}$ & $\begin{array}{c}0.196^{* * *} \\
(0.071)\end{array}$ & $\begin{array}{c}0.014 \\
(0.044)\end{array}$ \\
\hline Observations & 9576 & 11172 & 8374 & 11036 & 11179 & 8406 & 11040 \\
\hline \multicolumn{8}{|c|}{ E. Dropping Zurich } \\
\hline Free $_{t} \cdot I\left(d_{m} \leq 15\right)$ & $\begin{array}{c}0.056^{* * *} \\
(0.015)\end{array}$ & $\begin{array}{l}-0.003 \\
(0.021)\end{array}$ & $\begin{array}{c}0.040^{* *} \\
(0.016)\end{array}$ & $\begin{array}{l}-0.020 \\
(0.022)\end{array}$ & $\begin{array}{c}0.045 \\
(0.046)\end{array}$ & $\begin{array}{c}0.149^{* *} \\
(0.066)\end{array}$ & $\begin{array}{c}0.010 \\
(0.051)\end{array}$ \\
\hline Free $_{t} \cdot I\left(15<d_{m} \leq 30\right)$ & $\begin{array}{c}0.021^{* *} \\
(0.010)\end{array}$ & $\begin{array}{c}0.007 \\
(0.007)\end{array}$ & $\begin{array}{c}0.006 \\
(0.013)\end{array}$ & $\begin{array}{l}-0.002 \\
(0.007)\end{array}$ & $\begin{array}{l}0.078^{*} \\
(0.041)\end{array}$ & $\begin{array}{l}0.187^{* *} \\
(0.084)\end{array}$ & $\begin{array}{r}0.046 \\
(0.039)\end{array}$ \\
\hline Observations & 9576 & 11172 & 8374 & 11036 & 11179 & 8406 & 11040 \\
\hline $\begin{array}{l}\text { Year/Area fixed effects } \\
\text { Nuts-II trends }\end{array}$ & $\sqrt{ }$ & $\begin{array}{l}\sqrt{ } \\
\sqrt{ }\end{array}$ & $\sqrt{V}$ & $\begin{array}{l}\sqrt{ } \\
\sqrt{ }\end{array}$ & $\sqrt{ }$ & $\begin{array}{l}\sqrt{ } \\
\sqrt{ }\end{array}$ & $\begin{array}{l}\sqrt{ } \\
\sqrt{ }\end{array}$ \\
\hline
\end{tabular}

Notes: This table shows the robustness of the reform effect on wages and employment of natives by education group based on regression specification (1). In column 1, the dependent variable is the total number of immigrants standardized by total employment in 1998. In column $2-4$, the dependent variable is the mean log hourly real wage by education group. The dependent variable in column $5-7$ is the log number of native full-time equivalents worked by natives by education group. Panel A repeats estimates from the baseline specification as in Table A.5 with the BR 30+ as control group. In Panel B-E, Geneva, Basel, Lugano, and Zurich, respectively, are omitted from the sample (using the BR $30+$ as control group). Freet is one for municipalities in the border region after 2004. $\left(d_{i} \leq x\right)$ and $\left(y<d_{i} \leq z\right)$ indicate whether a municipality is located less than $x$ travel minutes or between $y$ and $z$ travel minutes from the next border crossing, respectively. Distance interactions with the transition phase are omitted for brevity. Regressions are weighted using the total number of natives in a cell. Robust standard errors, clustered by commuting zone, are given in parentheses. ${ }^{* * *},{ }^{* *},{ }^{*}$, denote statistical significance at the $1 \%, 5 \%$ and $10 \%$ level, respectively. SESS data. 
Table A.8: Labor market results with alternative computation of standard errors

\begin{tabular}{|c|c|c|c|c|c|c|c|}
\hline \multirow[t]{3}{*}{ Dependent variable } & \multirow{3}{*}{$\begin{array}{c}\begin{array}{c}\text { Immi- } \\
\text { grants / }\end{array} \\
\text { Emp '98 } \\
(1)\end{array}$} & \multicolumn{3}{|c|}{$\begin{array}{l}\text { Mean log hourly wages } \\
\text { by education group }\end{array}$} & \multicolumn{3}{|c|}{$\begin{array}{l}\text { Log \# full-time equivalents } \\
\text { by education group }\end{array}$} \\
\hline & & all & high & lower & all & high & lower \\
\hline & & $(2)$ & $(3)$ & $(4)$ & $(5)$ & $(6)$ & $(7)$ \\
\hline \multicolumn{8}{|c|}{ A. Baseline } \\
\hline Free $_{t} \cdot I\left(d_{m} \leq 15\right)$ & $\begin{array}{c}0.056^{* * *} \\
(0.014)\end{array}$ & $\begin{array}{l}-0.002 \\
(0.021)\end{array}$ & $\begin{array}{c}0.045^{* * *} \\
(0.015)\end{array}$ & $\begin{array}{l}-0.022 \\
(0.022)\end{array}$ & $\begin{array}{c}0.040 \\
(0.045)\end{array}$ & $\begin{array}{c}0.163^{* *} \\
(0.064)\end{array}$ & $\begin{array}{l}-0.003 \\
(0.051)\end{array}$ \\
\hline Free $_{t} \cdot I\left(15<d_{m} \leq 30\right)$ & $\begin{array}{l}0.022^{* * *} \\
(0.008)\end{array}$ & $\begin{array}{c}0.009 \\
(0.006)\end{array}$ & $\begin{array}{c}0.015 \\
(0.012)\end{array}$ & $\begin{array}{l}-0.006 \\
(0.007)\end{array}$ & $\begin{array}{c}0.059 \\
(0.039)\end{array}$ & $\begin{array}{c}0.193^{* * *} \\
(0.072)\end{array}$ & $\begin{array}{c}0.014 \\
(0.044)\end{array}$ \\
\hline $\begin{array}{l}\text { Observations } \\
\text { Number of clusters }\end{array}$ & $\begin{array}{l}9585 \\
72\end{array}$ & 11181 & 8383 & 11045 & 11188 & 8415 & 11049 \\
\hline \multicolumn{8}{|c|}{ B. SE clustered at municipality level } \\
\hline Free $_{t} \cdot I\left(d_{m} \leq 15\right)$ & $\begin{array}{c}0.056^{* * *} \\
(0.012)\end{array}$ & $\begin{array}{l}-0.002 \\
(0.019)\end{array}$ & $\begin{array}{c}0.045^{* * *} \\
(0.013)\end{array}$ & $\begin{array}{l}-0.022 \\
(0.020)\end{array}$ & $\begin{array}{c}0.040 \\
(0.039)\end{array}$ & $\begin{array}{r}0.163^{* *} \\
(0.066)\end{array}$ & $\begin{array}{l}-0.003 \\
(0.047)\end{array}$ \\
\hline Free $_{t} \cdot I\left(15<d_{m} \leq 30\right)$ & $\begin{array}{l}0.022^{* * *} \\
(0.009)\end{array}$ & $\begin{array}{c}0.009 \\
(0.007)\end{array}$ & $\begin{array}{c}0.015 \\
(0.011)\end{array}$ & $\begin{array}{l}-0.006 \\
(0.007)\end{array}$ & $\begin{array}{l}0.059^{*} \\
(0.034)\end{array}$ & $\begin{array}{c}0.193^{* * *} \\
(0.060)\end{array}$ & $\begin{array}{c}0.014 \\
(0.037)\end{array}$ \\
\hline Observations & 9585 & 11181 & 8383 & 11045 & 11188 & 8415 & 11049 \\
\hline Number of clusters & 1065 & 1464 & 1271 & 1459 & 1464 & 1273 & 1459 \\
\hline \multicolumn{8}{|c|}{ C. SE clustered at canton level } \\
\hline Free $_{t} \cdot I\left(d_{m} \leq 15\right)$ & $\begin{array}{c}0.056^{* * *} \\
(0.016)\end{array}$ & $\begin{array}{l}-0.002 \\
(0.023)\end{array}$ & $\begin{array}{c}0.045^{* *} \\
(0.016)\end{array}$ & $\begin{array}{l}-0.022 \\
(0.024)\end{array}$ & $\begin{array}{c}0.040 \\
(0.047)\end{array}$ & $\begin{array}{c}0.163^{* *} \\
(0.059)\end{array}$ & $\begin{array}{l}-0.003 \\
(0.058)\end{array}$ \\
\hline Free $_{t} \cdot I\left(15<d_{m} \leq 30\right)$ & $\begin{array}{l}0.022^{* * *} \\
(0.007)\end{array}$ & $\begin{array}{c}0.009 \\
(0.006)\end{array}$ & $\begin{array}{c}0.015^{* *} \\
(0.006)\end{array}$ & $\begin{array}{l}-0.006 \\
(0.009)\end{array}$ & $\begin{array}{c}0.059 \\
(0.036)\end{array}$ & $\begin{array}{c}0.193^{* *} \\
(0.070)\end{array}$ & $\begin{array}{c}0.014 \\
(0.044)\end{array}$ \\
\hline Observations & 9585 & 11181 & 8383 & 11045 & 11188 & 8415 & 11049 \\
\hline Number of clusters & 18 & 18 & 18 & 18 & 18 & 18 & 18 \\
\hline \multicolumn{8}{|c|}{ D. SHAC variance } \\
\hline Free $_{t} \cdot I\left(d_{m} \leq 15\right)$ & $\begin{array}{c}0.056^{* * *} \\
(0.016)\end{array}$ & $\begin{array}{l}-0.002 \\
(0.016)\end{array}$ & $\begin{array}{c}0.045^{* * *} \\
(0.014)\end{array}$ & $\begin{array}{l}-0.022 \\
(0.016)\end{array}$ & $\begin{array}{c}0.040 \\
(0.027)\end{array}$ & $\begin{array}{c}0.163^{* * *} \\
(0.053)\end{array}$ & $\begin{array}{l}-0.003 \\
(0.031)\end{array}$ \\
\hline Free $_{t} \cdot I\left(15<d_{m} \leq 30\right)$ & $\begin{array}{l}0.022^{* * *} \\
(0.007)\end{array}$ & $\begin{array}{c}0.009 \\
(0.007)\end{array}$ & $\begin{array}{r}0.015^{* *} \\
(0.007)\end{array}$ & $\begin{array}{l}-0.006 \\
(0.007)\end{array}$ & $\begin{array}{c}0.059^{* *} \\
(0.026)\end{array}$ & $\begin{array}{c}0.193^{* * *} \\
(0.055)\end{array}$ & $\begin{array}{c}0.014 \\
(0.027)\end{array}$ \\
\hline Observations & 9585 & 11181 & 8383 & 11045 & 11188 & 8415 & 11049 \\
\hline $\begin{array}{l}\text { Year and area fixed effects } \\
\text { Nuts-II trends }\end{array}$ & $\begin{array}{l}\sqrt{ } \\
\sqrt{ }\end{array}$ & $\sqrt{\sqrt{ }}$ & $\begin{array}{l}\sqrt{ } \\
\sqrt{ }\end{array}$ & $\sqrt{ }$ & $\sqrt{\sqrt{ }}$ & $\begin{array}{l}\sqrt{ } \\
\sqrt{ }\end{array}$ & $\begin{array}{l}\sqrt{ } \\
\sqrt{ }\end{array}$ \\
\hline
\end{tabular}

Notes: This table shows the robustness of the reform effect on wages and employment of natives by education group based on regression specification (1). In column 1, the dependent variable is the total number of immigrants standardized by total employment in 1998. In column $2-4$, the dependent variable is the mean log hourly real wage by education group. The dependent variable in column $5-7$ is the $\log$ number of native full-time equivalents worked by natives by education group. Panel A repeats estimates from the baseline specification as in Table A.5 with standard errors, clustered by commuting zone. In panel B and $\mathrm{C}$ standard errors are clustered at the level of municipalities and Cantons, respectively. In panel D, we report standard errors based on the Spatial Heteroscedasticity and Autocorrelation Consistent (SHAC) variance estimator initially proposed by Conley (1999) and recently advanced by Colella et al. (2018). This estimator allows for correlation between areas that are geographically close but belong to different regional units. Following Dustmann et al. (2017), we use a uniform kernel and a bandwidth of 100 kilometers. Free $e_{t}$ is one for municipalities in the border region after 2004. $\left(d_{i} \leq x\right)$ and $\left(y<d_{i} \leq z\right)$ indicate whether a municipality is located less than $x$ travel minutes or between $y$ and $z$ travel minutes from the next border crossing, respectively. Distance interactions with the transition phase are omitted for brevity. Regressions are weighted using the total number of natives in a cell. ${ }^{* * *}{ }^{* *}{ }^{*}$, denote statistical significance at the $1 \%, 5 \%$ and $10 \%$ level, respectively. SESS data. 
Table A.9: Effect of free movement policy on wage levels of natives by sector of employment (control group: NBR)

Dependent variable: mean log hourly wage of natives by education group and sector of employment

\begin{tabular}{|c|c|c|c|c|}
\hline \multirow[t]{3}{*}{ Category of employment } & \multicolumn{2}{|c|}{ Manufacturing } & \multicolumn{2}{|c|}{ Services } \\
\hline & High-tech & Low-tech & $\begin{array}{l}\text { Knowl.- } \\
\text { intensive }\end{array}$ & $\begin{array}{c}\text { Not-Knowl. } \\
\text { intensive }\end{array}$ \\
\hline & $(1)$ & $(2)$ & $(3)$ & $(4)$ \\
\hline
\end{tabular}

A. All education groups

$\begin{array}{lcccc}\text { Free }_{t} \cdot I\left(d_{m} \leq 15\right) & 0.029^{*} & 0.016 & 0.015 & -0.011 \\ & (0.017) & (0.016) & (0.018) & (0.020) \\ \text { Free }_{t} \cdot I\left(15<d_{m} \leq 30\right) & -0.011 & 0.019 & -0.002 & 0.005 \\ & (0.015) & (0.013) & (0.012) & (0.013)\end{array}$

E. Highly educated

$\begin{array}{lcccc}\text { Free }_{t} \cdot I\left(d_{m} \leq 15\right) & 0.006 & 0.003 & 0.058^{* * *} & 0.071^{* * *} \\ & (0.018) & (0.029) & (0.015) & (0.022) \\ \text { Free }_{t} \cdot I\left(15<d_{m} \leq 30\right) & 0.032^{* *} & 0.028 & 0.009 & 0.037 \\ & (0.015) & (0.020) & (0.013) & (0.025)\end{array}$

F. Lower educated

\begin{tabular}{lcccc} 
Free $_{t} \cdot I\left(d_{m} \leq 15\right)$ & $0.033^{*}$ & 0.010 & -0.008 & -0.021 \\
& $(0.018)$ & $(0.015)$ & $(0.017)$ & $(0.019)$ \\
Free $_{t} \cdot I\left(15<d_{m} \leq 30\right)$ & -0.008 & 0.010 & -0.008 & -0.006 \\
& $(0.016)$ & $(0.013)$ & $(0.012)$ & $(0.013)$ \\
\hline Year/Area fixed effects & $\sqrt{ }$ & $\sqrt{ }$ & $\sqrt{ }$ & $\sqrt{ }$ \\
Nuts-II trends & $\sqrt{ }$ & $\sqrt{ }$ & $\sqrt{ }$ & $\sqrt{ }$ \\
\hline
\end{tabular}

Notes: This table shows the effect on wages of natives by sector of employment and education based on regression specification (1). Municipalities in the NBR constitute the control group. High-tech manufacturing is NACE Rev 1.1 industries $24,29,30,31,32,33,34$ and 35 excluding 35.1. Low-tech manufacturers are the remainder manufacturing categories. Knowledge-intensive services are NACE Rev 1.1 industries 61, 62, 64, 65-67, 70-74, 80, 85, 92. Not knowledgeintensive services are the remainder service sector categories. Freet is one from year 2004 onward. $\left(d_{i} \leq x\right)$ and $\left(y<d_{i} \leq z\right)$ indicate whether a municipality is located less than $x$ travel minutes or between $y$ and $z$ travel minutes from the next border crossing, respectively. Distance interactions with the transition phase are omitted for brevity. Regressions are weighted using the total number of natives in a cell. Robust standard errors, clustered by commuting zone, are given in parentheses. ${ }^{* * *},{ }^{* *},{ }^{*}$, denote statistical significance at the $1 \%, 5 \%$ and $10 \%$ level, respectively. SESS data. 
Table A.10: Effect of free movement policy on immigrants by education group relative to total employment 1998, by sector of employment

Dependent variable: number of immigrants by sector of employment and education standardized by total sectoral employment in 1998

\begin{tabular}{|c|c|c|c|c|}
\hline \multirow[t]{3}{*}{ Category of employment } & \multicolumn{2}{|c|}{ Manufacturing } & \multicolumn{2}{|c|}{ Services } \\
\hline & High-tech & Low-tech & $\begin{array}{l}\text { Knowl.- } \\
\text { intensive }\end{array}$ & $\begin{array}{c}\text { Not-Knowl. } \\
\text { intensive }\end{array}$ \\
\hline & (1) & $(2)$ & $(3)$ & (4) \\
\hline
\end{tabular}

I. Control group: BR 30+

$\begin{array}{lcccc}\text { Free }_{t} \cdot I\left(d_{m} \leq 15\right) & 0.069^{*} & -0.033 & 0.084^{* * *} & 0.046^{* *} \\ \text { Free }_{t} \cdot I\left(15<d_{m} \leq 30\right) & (0.038) & (0.021) & (0.015) & (0.021) \\ & 0.033 & -0.004 & 0.033^{* *} & 0.006 \\ (0.024) & (0.011) & (0.014) & (0.016)\end{array}$

B. Highly educated

$\begin{array}{lcccc}\text { Free }_{t} \cdot I\left(d_{m} \leq 15\right) & 0.037^{* *} & 0.008^{*} & 0.058^{* * *} & 0.025^{* * *} \\ \text { Free }_{t} \cdot I\left(15<d_{m} \leq 30\right) & (0.017) & (0.005) & (0.007) & (0.008) \\ & 0.009 & -0.000 & 0.021^{* *} & 0.003 \\ & (0.011) & (0.003) & (0.008) & (0.004)\end{array}$

C. Lower educated

$\begin{array}{lcccc}\text { Free }_{t} \cdot I\left(d_{m} \leq 15\right) & 0.031 & -0.041^{* *} & 0.026^{* *} & 0.021 \\ & (0.029) & (0.020) & (0.011) & (0.016) \\ \text { Free }_{t} \cdot I\left(15<d_{m} \leq 30\right) & 0.024 & -0.003 & 0.012 & 0.003 \\ & (0.017) & (0.010) & (0.008) & (0.014)\end{array}$

II. Control group: NBR

D. All education groups

$\begin{array}{lcccc}\text { Free }_{t} \cdot I\left(d_{m} \leq 15\right) & 0.076^{*} & -0.047^{* *} & 0.042^{*} & 0.027 \\ & (0.041) & (0.023) & (0.024) & (0.020) \\ \text { Free }_{t} \cdot I\left(15<d_{m} \leq 30\right) & 0.043 & -0.016 & -0.002 & -0.012 \\ & (0.028) & (0.014) & (0.014) & (0.016)\end{array}$

E. Highly educated

$\begin{array}{lcccc}\text { Free }_{t} \cdot I\left(d_{m} \leq 15\right) & 0.033^{* *} & 0.007 & 0.028^{* *} & 0.025^{* * *} \\ \text { Free }_{t} \cdot I\left(15<d_{m} \leq 30\right) & (0.014) & (0.005) & (0.012) & (0.009) \\ & 0.007 & -0.002 & -0.005 & 0.003 \\ (0.012) & (0.004) & (0.008) & (0.006)\end{array}$

F. Lower educated

\begin{tabular}{lcccc} 
Free $_{t} \cdot I\left(d_{m} \leq 15\right)$ & 0.043 & $-0.054^{* *}$ & 0.014 & 0.002 \\
& $(0.034)$ & $(0.022)$ & $(0.015)$ & $(0.015)$ \\
Free $_{t} \cdot I\left(15<d_{m} \leq 30\right)$ & $0.036^{*}$ & -0.015 & 0.003 & -0.015 \\
& $(0.021)$ & $(0.012)$ & $(0.010)$ & $(0.014)$ \\
\hline \hline Year/Area fixed effects & $\sqrt{ }$ & $\sqrt{ }$ & $\sqrt{ }$ & $\sqrt{ }$ \\
Nuts-II trends & $\sqrt{ }$ & $\sqrt{ }$ & $\sqrt{ }$ & $\sqrt{ }$ \\
\hline
\end{tabular}

Notes: This table shows the effect of the free movement policy on the number of immigrants by sector of employment and education group standardized by total sectoral employment in 1998 based on regression specification (1). In panel A and $\mathrm{D}$ the sample includes immigrants from all education groups. In panel $\mathrm{B}$ and $\mathrm{E}$ (panel $\mathrm{C}$ and $\mathrm{F}$ ), the sample includes highly (lower) educated immigrants. In panel I.A-C municipalities in the BR 30+ are in the control group. In panel II.D-F municipalities in the NBR are the control group. High-tech manufacturing is NACE Rev 1.1 industries 24, 29, 30, 31, 32, 33, 34 and 35 excluding 35.1. Low-tech manufacturers are the remainder manufacturing categories. Knowledge-intensive services are NACE Rev 1.1 industries $61,62,64,65-67,70-74,80,85,92$. Not knowledge-intensive services are the remainder service sector categories. Freet is one from year 2004 onward. $\left(d_{i} \leq x\right)$ and $\left(y<d_{i} \leq z\right)$ indicate whether a municipality is located less than $x$ travel minutes or between $y$ and $z$ travel minutes from the next border crossing, respectively. Distance interactions with the transition phase are omitted for brevity. Regressions are weighted using the total employment in 1998 in a cell. Robust standard errors, clustered by commuting7zone, are given in parentheses. ${ }^{* * *},{ }^{* *},{ }^{*}$, denote statistical significance at the $1 \%, 5 \%$ and $10 \%$ level, respectively. SESS data. 
Table A.11: Effect of free movement policy on native employment and cumulative netflows of natives into local employment

\begin{tabular}{|c|c|c|c|c|c|c|}
\hline \multirow{3}{*}{ Dependent variable } & \multirow{3}{*}{$\begin{array}{c}\text { Emp / } \\
\text { Emp '98 } \\
(1)\end{array}$} & \multicolumn{4}{|c|}{ Cumulative net-flows from/to (In-Out) } & \multirow{3}{*}{$\begin{array}{c}\text { Pop / } \\
\text { Pop '98 } \\
(6) \\
\end{array}$} \\
\hline & & $\begin{array}{c}\text { Emp in } \\
\text { same bin } \\
\text { (other mun) }\end{array}$ & $\begin{array}{l}\text { Emp in } \\
\text { other } \\
\text { bins }\end{array}$ & $\begin{array}{l}\text { Non- } \\
\text { emp }\end{array}$ & Other & \\
\hline & & $(2)$ & $(3)$ & $(4)$ & $(5)$ & \\
\hline \multicolumn{7}{|c|}{ I. Control group: BR 30+ } \\
\hline \multicolumn{7}{|c|}{ A. All education groups } \\
\hline Freet $\cdot I\left(d_{m} \leq 15\right)$ & $\begin{array}{c}0.052 \\
(0.077)\end{array}$ & $\begin{array}{l}-0.011 \\
(0.026)\end{array}$ & $\begin{array}{c}0.013 \\
(0.040)\end{array}$ & $\begin{array}{l}-0.038 \\
(0.042)\end{array}$ & $\begin{array}{c}0.088 \\
(0.106)\end{array}$ & $\begin{array}{c}0.067 \\
(0.051)\end{array}$ \\
\hline Free $_{t} \cdot I\left(15<d_{m} \leq 30\right)$ & $\begin{array}{c}0.086 \\
(0.074)\end{array}$ & $\begin{array}{l}-0.009 \\
(0.024)\end{array}$ & $\begin{array}{c}0.005 \\
(0.049)\end{array}$ & $\begin{array}{l}-0.026 \\
(0.026)\end{array}$ & $\begin{array}{c}0.115 \\
(0.102)\end{array}$ & $\begin{array}{c}0.049 \\
(0.034)\end{array}$ \\
\hline Observations & 5189 & 5189 & 5189 & 5189 & 5189 & 15334 \\
\hline \multicolumn{7}{|c|}{ B. Highly educated } \\
\hline Free $_{t} \cdot I\left(d_{m} \leq 15\right)$ & $\begin{array}{c}0.203 \\
(0.158)\end{array}$ & $\begin{array}{l}-0.063 \\
(0.059)\end{array}$ & $\begin{array}{c}0.055 \\
(0.074)\end{array}$ & $\begin{array}{c}0.164^{* * *} \\
(0.060)\end{array}$ & $\begin{array}{c}0.047 \\
(0.221)\end{array}$ & $\begin{array}{c}0.080 \\
(0.098)\end{array}$ \\
\hline Freet $_{t} \cdot I\left(15<d_{m} \leq 30\right)$ & $\begin{array}{c}0.228 \\
(0.174)\end{array}$ & $\begin{array}{l}-0.074 \\
(0.046)\end{array}$ & $\begin{array}{c}0.004 \\
(0.073)\end{array}$ & $\begin{array}{c}0.069 \\
(0.043)\end{array}$ & $\begin{array}{c}0.229 \\
(0.265)\end{array}$ & $\begin{array}{c}0.017 \\
(0.087)\end{array}$ \\
\hline Observations & 1654 & 1654 & 1654 & 1654 & 1654 & 6301 \\
\hline \multicolumn{7}{|c|}{ C. Lower educated } \\
\hline Freet $_{t} \cdot I\left(d_{m} \leq 15\right)$ & $\begin{array}{c}0.008 \\
(0.067)\end{array}$ & $\begin{array}{l}-0.010 \\
(0.030)\end{array}$ & $\begin{array}{l}-0.010 \\
(0.043)\end{array}$ & $\begin{array}{c}-0.093^{* *} \\
(0.043)\end{array}$ & $\begin{array}{c}0.122 \\
(0.105)\end{array}$ & $\begin{array}{c}0.040 \\
(0.051)\end{array}$ \\
\hline Free $_{t} \cdot I\left(15<d_{m} \leq 30\right)$ & $\begin{array}{c}0.049 \\
(0.072)\end{array}$ & $\begin{array}{l}-0.002 \\
(0.027)\end{array}$ & $\begin{array}{l}-0.004 \\
(0.050)\end{array}$ & $\begin{array}{l}-0.048 \\
(0.035)\end{array}$ & $\begin{array}{c}0.104 \\
(0.095)\end{array}$ & $\begin{array}{c}0.043 \\
(0.035)\end{array}$ \\
\hline Observations & 4529 & 4529 & 4529 & 4529 & 4529 & 13937 \\
\hline \multicolumn{7}{|c|}{ II. Control group: NBR } \\
\hline \multicolumn{7}{|c|}{ D. All education groups } \\
\hline Free $_{t} \cdot I\left(d_{m} \leq 15\right)$ & $\begin{array}{c}0.078 \\
(0.078)\end{array}$ & $\begin{array}{c}0.007 \\
(0.025)\end{array}$ & $\begin{array}{c}0.017 \\
(0.026)\end{array}$ & $\begin{array}{l}-0.020 \\
(0.032)\end{array}$ & $\begin{array}{c}0.074 \\
(0.088)\end{array}$ & $\begin{array}{c}0.043 \\
(0.046)\end{array}$ \\
\hline Free $_{t} \cdot I\left(15<d_{m} \leq 30\right)$ & $\begin{array}{l}0.121^{*} \\
(0.062)\end{array}$ & $\begin{array}{c}0.008 \\
(0.023)\end{array}$ & $\begin{array}{c}0.030 \\
(0.019)\end{array}$ & $\begin{array}{c}0.001 \\
(0.026)\end{array}$ & $\begin{array}{c}0.082 \\
(0.063)\end{array}$ & $\begin{array}{c}0.032 \\
(0.033)\end{array}$ \\
\hline Observations & 6417 & 6417 & 6417 & 6417 & 6417 & 19662 \\
\hline \multicolumn{7}{|c|}{ E. Highly educated } \\
\hline Free $_{t} \cdot I\left(d_{m} \leq 15\right)$ & $\begin{array}{l}0.293^{*} \\
(0.173)\end{array}$ & $\begin{array}{l}-0.007 \\
(0.083)\end{array}$ & $\begin{array}{c}0.069 \\
(0.064)\end{array}$ & $\begin{array}{c}0.021 \\
(0.083)\end{array}$ & $\begin{array}{c}0.210 \\
(0.262)\end{array}$ & $\begin{array}{c}0.074 \\
(0.102)\end{array}$ \\
\hline Freet $_{t} \cdot I\left(15<d_{m} \leq 30\right)$ & $\begin{array}{l}0.301^{*} \\
(0.173)\end{array}$ & $\begin{array}{l}-0.033 \\
(0.086)\end{array}$ & $\begin{array}{c}0.056 \\
(0.059)\end{array}$ & $\begin{array}{l}-0.072 \\
(0.089)\end{array}$ & $\begin{array}{c}0.350 \\
(0.286)\end{array}$ & $\begin{array}{l}-0.014 \\
(0.084)\end{array}$ \\
\hline Observations & 2068 & 2068 & 2068 & 2068 & 2068 & 7778 \\
\hline \multicolumn{7}{|c|}{ F. Lower educated } \\
\hline Free $_{t} \cdot I\left(d_{m} \leq 15\right)$ & $\begin{array}{c}0.039 \\
(0.069)\end{array}$ & $\begin{array}{l}-0.003 \\
(0.031)\end{array}$ & $\begin{array}{l}-0.001 \\
(0.029)\end{array}$ & $\begin{array}{l}-0.055 \\
(0.039)\end{array}$ & $\begin{array}{c}0.098 \\
(0.081)\end{array}$ & $\begin{array}{c}0.032 \\
(0.042)\end{array}$ \\
\hline Free $_{t} \cdot I\left(15<d_{m} \leq 30\right)$ & $\begin{array}{c}0.087 \\
(0.057)\end{array}$ & $\begin{array}{c}0.007 \\
(0.027)\end{array}$ & $\begin{array}{c}0.020 \\
(0.021)\end{array}$ & $\begin{array}{c}0.006 \\
(0.033)\end{array}$ & $\begin{array}{c}0.053 \\
(0.056)\end{array}$ & $\begin{array}{c}0.044 \\
(0.031)\end{array}$ \\
\hline Observations & 5681 & 5681 & 5681 & 5681 & 5681 & 17882 \\
\hline Year/Area fixed effects & $\sqrt{ }$ & $\sqrt{ }$ & $\sqrt{ }$ & $\sqrt{ }$ & $\sqrt{ }$ & $\sqrt{ }$ \\
\hline Nuts-II trends & $\sqrt{ }$ & $\sqrt{ }$ & $\sqrt{ }$ & $\sqrt{ }$ & $\sqrt{ }$ & $\sqrt{ }$ \\
\hline
\end{tabular}

Notes: This table shows the effect of the free movement policy on native employment, their cumulative net-flows into from local employment and on native population based on regression specification (1). In column 1, the dependent variable is native employment in municipality $m$ in year $t$ divided by native employment in 1998 in the same municipality. Changes in total employment can be decomposed into four cumulative net-flows components (column 2-5). See Appendix B.1 for details on the construction of these variables. In column 2, the dependent variable is the cumulative net-flow (inflow minus outflow) from other municipalities in the same distance bin $(0-15,15-30,30+$ or NBR) standardized by total employment in 1998. In column 3 , the dependent variable is the cumulative net-flow from municipalities in other bins. Column 4 shows cumulative net-flows from non-employment (unemployment or out of the labor force). Column 5 shows cumulative net-flows from a residual category other (out of the sample, age range, missing values, etc.). In column 6 , the dependent variable is the population in municipality $m$ in year $t$ standardized by its population in 1998. In Panel I.A to I.C municipalities in the border region farther away than 30 minutes constitute the control group. In Panel II.D to II.F municipalities in the non-border region are the control group. Free $t_{t}$ is one from year 2004 onward. $\left(d_{i} \leq x\right)$ and $\left(y<d_{i} \leq z\right)$ indicate whether a municipality is located less than $x$ travel minutes or between $y$ and $z$ travel minutes from the next border crossing, respectively. Distance interactions with the transition phase are omitted for brevity. Regressions are weighted using the total number of natives 1998 . Robust standard errors, clustered by commuting zone, are given in parentheses. ${ }^{* * *},{ }^{* *},{ }^{*}$, denote statistical significance at the $1 \%, 5 \%$ and $10 \%$ level, respectively. SLFS data 1996-2009. 
Table A.12: Characteristics of firms depending on pre-reform skill shortage

\begin{tabular}{|c|c|c|c|c|c|c|}
\hline & \multicolumn{2}{|c|}{$\begin{array}{c}(1) \\
\text { No shortage }\end{array}$} & \multicolumn{2}{|c|}{$\begin{array}{c}(2) \\
\text { Moderate }\end{array}$} & \multicolumn{2}{|c|}{$\begin{array}{c}(3) \\
\text { High shortage }\end{array}$} \\
\hline & mean & sd & mean & sd & mean & sd \\
\hline FTE employment (ln) & 3.84 & $(1.52)$ & 4.26 & $(1.48)$ & 3.95 & $(1.43)$ \\
\hline Firm age & 47.83 & $(47.10)$ & 48.63 & $(38.22)$ & 45.52 & $(37.56)$ \\
\hline High-tech manufacturing & 0.18 & $(0.38)$ & 0.25 & $(0.43)$ & 0.22 & $(0.41)$ \\
\hline Low-tech manufacturing & 0.25 & $(0.43)$ & 0.34 & $(0.47)$ & 0.34 & $(0.47)$ \\
\hline Knowl.-intensive services & 0.18 & $(0.38)$ & 0.13 & $(0.33)$ & 0.11 & $(0.32)$ \\
\hline Not-knowl.-intensive services & 0.27 & $(0.44)$ & 0.19 & $(0.39)$ & 0.23 & $(0.42)$ \\
\hline Firms with R\&D expenditures & 0.42 & $(0.49)$ & 0.58 & $(0.49)$ & 0.52 & $(0.50)$ \\
\hline Export share in sales (\%) & 19.03 & $(31.43)$ & 23.58 & $(33.38)$ & 20.93 & $(31.96)$ \\
\hline Firms with foreign owner & 0.12 & $(0.32)$ & 0.11 & $(0.31)$ & 0.12 & $(0.32)$ \\
\hline Share academics in workforce $(\%)$ & 17.26 & $(20.50)$ & 17.07 & $(17.80)$ & 16.49 & $(18.95)$ \\
\hline Value added per FTE worker (ln) & 11.77 & $(0.59)$ & 11.76 & $(0.55)$ & 11.72 & $(0.64)$ \\
\hline Number of competitors & 28.24 & $(29.49)$ & 26.32 & $(27.86)$ & 28.89 & $(29.07)$ \\
\hline Highly hampered by LMRF & 0.05 & $(0.23)$ & 0.12 & $(0.33)$ & 0.27 & $(0.44)$ \\
\hline Travel minutes to border & 31.80 & $(20.21)$ & 30.84 & $(19.22)$ & 31.29 & $(19.19)$ \\
\hline Observations & 1096 & & 1755 & & 609 & \\
\hline
\end{tabular}

Notes: The table shows average firm characteristics using data from the KOF innovation surveys 1996 and 1999. Entries represent averages per region of all firm-year observations in the surveys. We differentiate firms that differed in the extent to which they reported that their innovation efforts were negatively affected by a "shortage of specialized personnel". The original variable has a 5-point Likert scale. Firms that have "no shortage" are firms with a less than 2, "moderate shortage" firms have a value between 2 and 4, and "high shortage" firms have a value greater than or equal to 4 . High-tech manufacturing is NACE rev. 1.1 industries 24 and 29-35 excluding 35.1. "Highly hampered by LMRF" are firms that reported that their innovation efforts were strongly negatively affected by labor market regulation for foreigners in 1996 and/or 1999 . 
Table A.13: Further heterogeneity of firm-level effects of free movement policy

\begin{tabular}{cccc}
\hline \hline & $(1)$ & $(2)$ & $(3)$ \\
& FE & FE & FE \\
VARIABLES & Sales & Produc- & Patent \\
& & tivity & count \\
\hline
\end{tabular}

\begin{tabular}{|c|c|c|c|}
\hline \multicolumn{4}{|l|}{ A: Firm size } \\
\hline Free $_{t} * I\left(d_{i} \leq 15\right)$ & $\begin{array}{c}0.136^{* *} \\
(0.060)\end{array}$ & $\begin{array}{l}-0.001 \\
(0.041)\end{array}$ & $\begin{array}{c}0.128^{* * *} \\
(0.043)\end{array}$ \\
\hline Free $_{t} * I\left(d_{i} \leq 15\right) * I(F T E \geq 100)$ & $\begin{array}{l}-0.045 \\
(0.061)\end{array}$ & $\begin{array}{c}0.098^{* * *} \\
(0.034)\end{array}$ & $\begin{array}{l}-0.007 \\
(0.060)\end{array}$ \\
\hline \multicolumn{4}{|l|}{ B: High vs. low CBW share } \\
\hline Free $_{t} * I\left(d_{i} \leq 15\right)$ & $\begin{array}{c}0.119^{* *} \\
(0.053)\end{array}$ & $\begin{array}{c}0.005 \\
(0.035)\end{array}$ & $\begin{array}{c}0.144^{* * *} \\
(0.046)\end{array}$ \\
\hline Free $_{t} * I\left(d_{i} \leq 15\right) *$ Ind. CBW share $\geq 10 \%$ & $\begin{array}{c}0.010 \\
(0.053)\end{array}$ & $\begin{array}{c}0.082 \\
(0.061)\end{array}$ & $\begin{array}{c}-0.051 \\
(0.063)\end{array}$ \\
\hline \multicolumn{4}{|l|}{ C: Export status } \\
\hline Free $_{t} * I\left(d_{i} \leq 15\right)$ & $\begin{array}{c}0.134^{* *} \\
(0.054)\end{array}$ & $\begin{array}{l}-0.019 \\
(0.044)\end{array}$ & $\begin{array}{c}0.102^{* *} \\
(0.039)\end{array}$ \\
\hline Free $_{t} * I\left(d_{i} \leq 15\right) *$ Exporter & $\begin{array}{c}0.001 \\
(0.047) \\
\end{array}$ & $\begin{array}{c}0.064 \\
(0.041) \\
\end{array}$ & $\begin{array}{c}0.062 \\
(0.060)\end{array}$ \\
\hline
\end{tabular}

Notes: Each panel contains separate regressions of our baseline firm-level DiD model (specification 1) using the IS 19962013, augmented with one or several interactions between indicators for subgroups of firms and Transition $_{t} * I\left(d_{i} \leq 15\right)$, Transition $_{t} * I\left(15<d_{i}<30\right)$, Free $_{t} * I\left(d_{i}<15\right)$, and Free $t * I\left(15<d_{i}<30\right)$. In the table, we focus on the effects on highly treated firms in the free movement phase. The indicators refer to firm size (in terms of FTE employment, panel A), whether the firm operates in an industry with a cross-border worker share exceeding $10 \%$ in 1998 in the BR (panel B), and firms' export share in sales (panel C). All regressions account for firm fixed effects, period fixed effects, and linear trends per Nuts-II region. The dependent variable in column 1 is firms' log total sales. The dependent variable in column 2 is firms' $\log$ value added per FTE worker. The dependent variable in column 3 is the inverse hyperbolic sine of the number of patent application filed by the firm in the three years preceding the survey. Freet is a dummy equal to one from year 2004 onward. $I\left(d_{i} \leq x\right)$ indicate whether a firm is located less than $x$ travel minutes from the next border crossing. Standard errors are clustered by commuting zone. 
Table A.14: Main robustness checks for firm-level results

\begin{tabular}{|c|c|c|c|c|c|c|}
\hline VARIABLES & $\begin{array}{c}(1) \\
\text { FE } \\
\text { Foreign } \\
\text { employ. }\end{array}$ & $\begin{array}{c}(2) \\
\text { FE } \\
\text { Establ. size } \\
\text { BC }\end{array}$ & $\begin{array}{c}(3) \\
\text { FE } \\
\text { Firm size } \\
\text { IS }\end{array}$ & $\begin{array}{c}(4) \\
\text { FE } \\
\text { Sales }\end{array}$ & $\begin{array}{c}(5) \\
\text { FE } \\
\text { Productivity }\end{array}$ & $\begin{array}{c}(6) \\
\text { FE } \\
\text { Patents } \\
0 / 1\end{array}$ \\
\hline \multicolumn{7}{|c|}{ A. Baseline } \\
\hline Free $_{t} * I\left(d_{i} \leq 15\right)$ & $\begin{array}{c}0.085^{* * *} \\
(0.020)\end{array}$ & $\begin{array}{c}0.062 * * * \\
(0.022)\end{array}$ & $\begin{array}{c}0.098^{* *} \\
(0.046)\end{array}$ & $\begin{array}{c}0.120^{* *} \\
(0.050)\end{array}$ & $\begin{array}{c}0.037 \\
(0.035)\end{array}$ & $\begin{array}{c}0.064^{* *} \\
(0.027)\end{array}$ \\
\hline Free $_{t} * I\left(15<d_{i} \leq 30\right)$ & $\begin{array}{c}0.034^{* * *} \\
(0.012)\end{array}$ & $\begin{array}{c}0.055^{* *} \\
(0.023)\end{array}$ & $\begin{array}{l}0.091^{*} \\
(0.046)\end{array}$ & $\begin{array}{c}0.049 \\
(0.044)\end{array}$ & $\begin{array}{l}-0.042 \\
(0.039)\end{array}$ & $\begin{array}{c}0.018 \\
(0.024)\end{array}$ \\
\hline Free $_{t} * I\left(d_{i} \leq 15\right)$ & $\begin{array}{c}0.088^{* * *} \\
(0.022)\end{array}$ & $\begin{array}{l}\text { B. Control g } \\
0.036^{*} \\
(0.020)\end{array}$ & $\begin{array}{c}\text { oup: NBR } \\
0.040 \\
(0.037)\end{array}$ & $\begin{array}{l}0.072^{*} \\
(0.042)\end{array}$ & $\begin{array}{c}0.040 \\
(0.036)\end{array}$ & $\begin{array}{l}0.048^{*} \\
(0.025)\end{array}$ \\
\hline Free $_{t} * I\left(15<d_{i} \leq 30\right)$ & $\begin{array}{c}0.037^{* * *} \\
(0.012)\end{array}$ & $\begin{array}{l}0.036^{* *} \\
(0.017)\end{array}$ & $\begin{array}{c}0.033 \\
(0.035)\end{array}$ & $\begin{array}{c}0.001 \\
(0.035)\end{array}$ & $\begin{array}{l}-0.040 \\
(0.038)\end{array}$ & $\begin{array}{c}0.002 \\
(0.017)\end{array}$ \\
\hline \multicolumn{7}{|c|}{ C. Omitting linear time trends } \\
\hline Free $_{t} * I\left(d_{i} \leq 15\right)$ & $\begin{array}{c}0.096^{* * *} \\
(0.021)\end{array}$ & $\begin{array}{c}0.059^{* *} \\
(0.027)\end{array}$ & $\begin{array}{c}0.097^{* *} \\
(0.046)\end{array}$ & $\begin{array}{c}0.119^{* *} \\
(0.050)\end{array}$ & $\begin{array}{c}0.037 \\
(0.035)\end{array}$ & $\begin{array}{c}0.064^{* *} \\
(0.026)\end{array}$ \\
\hline Free $_{t} * I\left(15<d_{i} \leq 30\right)$ & $\begin{array}{c}0.031^{* *} \\
(0.013)\end{array}$ & $\begin{array}{c}0.055^{* *} \\
(0.025)\end{array}$ & $\begin{array}{c}0.091^{* *} \\
(0.046)\end{array}$ & $\begin{array}{c}0.049 \\
(0.044)\end{array}$ & $\begin{array}{l}-0.042 \\
(0.039)\end{array}$ & $\begin{array}{c}0.020 \\
(0.024)\end{array}$ \\
\hline \multicolumn{7}{|c|}{ D. Industry-period effects } \\
\hline Free $_{t} * I\left(d_{i} \leq 15\right)$ & $\begin{array}{c}0.079^{* * *} \\
(0.020)\end{array}$ & $\begin{array}{c}0.060^{* * *} \\
(0.022)\end{array}$ & $\begin{array}{c}0.088^{* *} \\
(0.042)\end{array}$ & $\begin{array}{c}0.114^{* *} \\
(0.047)\end{array}$ & $\begin{array}{c}0.042 \\
(0.036)\end{array}$ & $\begin{array}{c}0.066^{* *} \\
(0.027)\end{array}$ \\
\hline Free $_{t} * I\left(15<d_{i} \leq 30\right)$ & $\begin{array}{c}0.030^{* *} \\
(0.012)\end{array}$ & $\begin{array}{c}0.055^{* *} \\
(0.021)\end{array}$ & $\begin{array}{l}0.087^{* *} \\
(0.043)\end{array}$ & $\begin{array}{c}0.047 \\
(0.042)\end{array}$ & $\begin{array}{l}-0.028 \\
(0.040)\end{array}$ & $\begin{array}{c}0.017 \\
(0.024)\end{array}$ \\
\hline \multicolumn{7}{|c|}{ E. Nuts-II period effects } \\
\hline 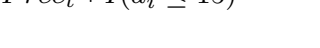 & $(0.021)$ & $(0.022)$ & $(0.046)$ & $(0.047)$ & $(0.038)$ & $(0.027)$ \\
\hline Free $_{t} * I\left(15<d_{i} \leq 30\right)$ & $\begin{array}{c}0.034^{* * *} \\
(0.012)\end{array}$ & $\begin{array}{c}0.055^{* *} \\
(0.022)\end{array}$ & $\begin{array}{l}0.101^{* *} \\
(0.045)\end{array}$ & $\begin{array}{c}0.059 \\
(0.047)\end{array}$ & $\begin{array}{l}-0.047 \\
(0.039)\end{array}$ & $\begin{array}{c}0.020 \\
(0.023)\end{array}$ \\
\hline \multicolumn{7}{|c|}{ F. Canton-period effects } \\
\hline Freet $* I\left(d_{i} \leq 15\right)$ & $\begin{array}{l}0.077^{*} \\
(0.045)\end{array}$ & $\begin{array}{c}0.035 \\
(0.031)\end{array}$ & $\begin{array}{c}0.168^{* * *} \\
(0.060)\end{array}$ & $\begin{array}{c}0.134^{* *} \\
(0.067)\end{array}$ & $\begin{array}{c}0.005 \\
(0.055)\end{array}$ & $\begin{array}{c}0.086^{* * *} \\
(0.032)\end{array}$ \\
\hline Free $_{t} * I\left(15<d_{i} \leq 30\right)$ & $\begin{array}{c}0.024^{* *} \\
(0.011)\end{array}$ & $\begin{array}{c}0.035 \\
(0.022)\end{array}$ & $\begin{array}{c}0.146^{* * *} \\
(0.054)\end{array}$ & $\begin{array}{c}0.096 \\
(0.061)\end{array}$ & $\begin{array}{l}-0.064 \\
(0.049)\end{array}$ & $\begin{array}{c}0.031 \\
(0.025)\end{array}$ \\
\hline \multicolumn{7}{|c|}{ G. Allowing for firm exit and entry } \\
\hline Freet $* I\left(d_{i} \leq 15\right)$ & $\begin{array}{c}0.094^{* * *} \\
(0.015)\end{array}$ & $\begin{array}{c}0.050^{* * *} \\
(0.017)\end{array}$ & $\begin{array}{c}0.097^{* *} \\
(0.047)\end{array}$ & $\begin{array}{c}0.120^{* *} \\
(0.050)\end{array}$ & $\begin{array}{c}0.037 \\
(0.035)\end{array}$ & $\begin{array}{c}0.064^{* *} \\
(0.027)\end{array}$ \\
\hline Free $_{t} * I\left(15<d_{i} \leq 30\right)$ & $\begin{array}{c}0.039^{* * *} \\
(0.010)\end{array}$ & $\begin{array}{c}0.056^{* * *} \\
(0.016)\end{array}$ & $\begin{array}{l}0.087^{*} \\
(0.046)\end{array}$ & $\begin{array}{c}0.046 \\
(0.044)\end{array}$ & $\begin{array}{l}-0.043 \\
(0.039)\end{array}$ & $\begin{array}{c}0.017 \\
(0.024)\end{array}$ \\
\hline \multicolumn{7}{|c|}{ H. Cross-section of firms in 1998} \\
\hline Freet $_{t} * I\left(d_{i} \leq 15\right)$ & $\begin{array}{c}0.101^{* * *} \\
(0.019)\end{array}$ & $\begin{array}{c}0.054^{* *} \\
(0.021)\end{array}$ & $\begin{array}{c}0.116^{* *} \\
(0.050)\end{array}$ & $\begin{array}{c}0.136^{* *} \\
(0.053)\end{array}$ & $\begin{array}{c}0.027 \\
(0.035)\end{array}$ & $\begin{array}{c}0.068^{* *} \\
(0.029)\end{array}$ \\
\hline Free $_{t} * I\left(15<d_{i} \leq 30\right)$ & $\begin{array}{c}0.036^{* * * *} \\
(0.012)\end{array}$ & $\begin{array}{c}0.050^{* * *} \\
(0.016)\end{array}$ & $\begin{array}{c}0.098^{* *} \\
(0.048)\end{array}$ & $\begin{array}{c}0.053 \\
(0.045)\end{array}$ & $\begin{array}{l}-0.052 \\
(0.039)\end{array}$ & $\begin{array}{c}0.023 \\
(0.024)\end{array}$ \\
\hline Free $_{t} * I\left(d_{i} \leq 15\right)$ & $\begin{array}{c}0.116^{* * *} \\
(0.036)\end{array}$ & $\begin{array}{l}\text { I. Includin } \\
0.092^{* * *} \\
(0.035)\end{array}$ & $\begin{array}{l}\text { outliers } \\
0.088^{*} \\
(0.049)\end{array}$ & $\begin{array}{c}0.109 * * \\
(0.054)\end{array}$ & $\begin{array}{c}0.026 \\
(0.041)\end{array}$ & $\begin{array}{c}0.063^{* *} \\
(0.027)\end{array}$ \\
\hline Free $_{t} * I\left(15<d_{i} \leq 30\right)$ & $\begin{array}{c}0.049 \\
(0.035)\end{array}$ & $\begin{array}{c}0.037 \\
(0.040)\end{array}$ & $\begin{array}{l}0.080^{*} \\
(0.047)\end{array}$ & $\begin{array}{c}0.036 \\
(0.045)\end{array}$ & $\begin{array}{l}-0.042 \\
(0.038)\end{array}$ & $\begin{array}{c}0.018 \\
(0.024)\end{array}$ \\
\hline Freet $* I\left(d_{i} \leq 15\right)$ & $\begin{array}{c}0.067^{* * *} \\
(0.014)\end{array}$ & $\begin{array}{c}\text { J. Unexposed } \\
0.076^{* * *} \\
(0.027)\end{array}$ & $\begin{array}{l}\text { Bilaterals } \\
0.101^{*} \\
(0.057)\end{array}$ & $\begin{array}{c}0.139^{* *} \\
(0.060)\end{array}$ & $\begin{array}{c}0.054 \\
(0.038)\end{array}$ & $\begin{array}{c}0.036 \\
(0.024)\end{array}$ \\
\hline Free $_{t} * I\left(15<d_{i} \leq 30\right)$ & $\begin{array}{c}0.026^{* *} \\
(0.012)\end{array}$ & $\begin{array}{c}0.063^{* *} \\
(0.025) \\
\end{array}$ & $\begin{array}{l}0.095^{*} \\
(0.055) \\
\end{array}$ & $\begin{array}{c}0.083 \\
(0.054) \\
\end{array}$ & $\begin{array}{l}-0.006 \\
(0.045)\end{array}$ & $\begin{array}{l}-0.016 \\
(0.026) \\
\end{array}$ \\
\hline
\end{tabular}

Notes: This table shows the robustness of the effect of the free movement policy with separate regressions, based on the baseline firm/establishment-level specification 1 using the BC (columns 1 and 2) and the IS (columns 3-6). All regressions account for establishment (BC) or firm (IS) fixed effects and period fixed effects, and all include linear trends per NUTS-II region (except panel C). The dependent variables are equivalent to those in Table 4 of the paper. The estimations in columns 1 and 2 are weighted using establishments' average size (in FTE). Panel A repeats our baseline results. In panel $\mathrm{B}$, highly and slightly treated firms are compared to establishments/firms in the non-border region (NBR). Panel $\mathrm{C}$ excludes the linear trends by region that are part of our baseline specification. In panels $\mathrm{D}$, $\mathrm{E}$, and F, we control for industry-period fixed effects (FE), NUTS-II-period FE, and canton-period FE, respectively. The regressions in panel $\mathrm{G}$ is not restricted to private-sector firms present throughout 1991-2011. Instead, we include firms that enter and exit in the sample period. Panel $\mathrm{H}$ focuses on the cross-section of firms/establishments existing in 1998. Panel I includes the few outliers dropped from the main samples. The regressions in panel $\mathrm{J}$ are restricted to two-digit industries that are unaffected by the bilateral agreements according to the classification by Bühler et al. (2011). Free $t$ is a dummy variable equal to one from year 2004 onward. $I\left(d_{i} \leq x\right)$ and $I\left(y<d_{i} \leq z\right)$ indicate whether a firm is located less than $x$ travel minutes or between $y$ and $z$ travel minutes from the next border crossing, respectively. The variables capturing the transition effects are included in the regression but omitted for brevity. Standard errors are clustered by commuting zone. ${ }^{* * *},{ }^{* *},{ }^{*}$, denote stą 9 stical significance at the $1 \%, 5 \%$ and $10 \%$ level, respectively. 
Table A.15: Firm results with alternative standard errors

\begin{tabular}{|c|c|c|c|c|}
\hline Dependent variable & $\begin{array}{c}\text { FTE (ln, IS) } \\
(1)\end{array}$ & $\begin{array}{c}\text { Sales }(\ln , \mathrm{IS}) \\
(2)\end{array}$ & $\begin{array}{c}\text { Value added per FTE } \\
(3)\end{array}$ & $\begin{array}{c}\text { Patents } 0 / 1 \\
(4)\end{array}$ \\
\hline \multicolumn{5}{|l|}{ A. Commuting zone } \\
\hline Free $_{t} * I\left(d_{i} \leq 15\right)$ & $\begin{array}{c}0.099 * * \\
(0.046)\end{array}$ & $\begin{array}{l}0.121^{* *} \\
(0.050)\end{array}$ & $\begin{array}{c}0.037 \\
(0.035)\end{array}$ & $\begin{array}{c}0.064^{* *} \\
(0.027)\end{array}$ \\
\hline Free $_{t} * I\left(15<d_{i} \leq 30\right)$ & $\begin{array}{l}0.092^{* *} \\
(0.046)\end{array}$ & $\begin{array}{c}0.050 \\
(0.044)\end{array}$ & $\begin{array}{l}-0.042 \\
(0.039)\end{array}$ & $\begin{array}{c}0.018 \\
(0.024)\end{array}$ \\
\hline Observations & 10,863 & 10,063 & 8,628 & 10,640 \\
\hline Number of clusters & 73 & 73 & 73 & 73 \\
\hline \multicolumn{5}{|l|}{ B. Firm } \\
\hline Free $_{t} * I\left(d_{i} \leq 15\right)$ & $\begin{array}{c}0.099^{* *} \\
(0.041)\end{array}$ & $\begin{array}{c}0.121^{* * *} \\
(0.046)\end{array}$ & $\begin{array}{c}0.037 \\
(0.038)\end{array}$ & $\begin{array}{c}0.064^{* * *} \\
(0.023)\end{array}$ \\
\hline Free $_{t} * I\left(15<d_{i} \leq 30\right)$ & $\begin{array}{c}0.092^{* *} \\
(0.039)\end{array}$ & $\begin{array}{c}0.050 \\
(0.041)\end{array}$ & $\begin{array}{l}-0.042 \\
(0.037)\end{array}$ & $\begin{array}{c}0.018 \\
(0.022)\end{array}$ \\
\hline Number of clusters & 4417 & 4193 & 3767 & 4368 \\
\hline \multicolumn{5}{|l|}{ C. Canton } \\
\hline Free $_{t} * I\left(d_{i} \leq 15\right)$ & $\begin{array}{c}0.099 * * \\
(0.042)\end{array}$ & $\begin{array}{c}0.121^{* * *} \\
(0.028)\end{array}$ & $\begin{array}{c}0.037 \\
(0.044)\end{array}$ & $\begin{array}{c}0.064^{* *} \\
(0.026)\end{array}$ \\
\hline Free $_{t} * I\left(15<d_{i} \leq 30\right)$ & $\begin{array}{c}0.092^{* *} \\
(0.042)\end{array}$ & $\begin{array}{c}0.050^{* *} \\
(0.019)\end{array}$ & $\begin{array}{l}-0.042 \\
(0.045)\end{array}$ & $\begin{array}{c}0.018 \\
(0.023)\end{array}$ \\
\hline Number of clusters & 23 & 23 & 22 & 23 \\
\hline \multicolumn{5}{|l|}{ D. Industry } \\
\hline Free $_{t} * I\left(d_{i} \leq 15\right)$ & $\begin{array}{c}0.099 * * \\
(0.042)\end{array}$ & $\begin{array}{l}0.121^{* *} \\
(0.046)\end{array}$ & $\begin{array}{c}0.037 \\
(0.042)\end{array}$ & $\begin{array}{c}0.064^{* *} \\
(0.028)\end{array}$ \\
\hline Free $_{t} * I\left(15<d_{i} \leq 30\right)$ & $\begin{array}{c}0.092^{* * *} \\
(0.034)\end{array}$ & $\begin{array}{c}0.050 \\
(0.041)\end{array}$ & $\begin{array}{l}-0.042 \\
(0.038)\end{array}$ & $\begin{array}{c}0.018 \\
(0.028)\end{array}$ \\
\hline Number of clusters & 67 & 67 & 66 & 67 \\
\hline E. SHAC variance & & & & \\
\hline Free $_{t} * I\left(d_{i} \leq 15\right)$ & $\begin{array}{c}0.099 * * * \\
(0.023)\end{array}$ & $\begin{array}{c}0.121^{* * *} \\
(0.015)\end{array}$ & $\begin{array}{c}0.037 \\
(0.029)\end{array}$ & $\begin{array}{c}0.064^{* * *} \\
(0.018)\end{array}$ \\
\hline Free $_{t} * I\left(15<d_{i} \leq 30\right)$ & $\begin{array}{c}0.092^{* * *} \\
(0.031)\end{array}$ & $\begin{array}{c}0.050 \\
(0.033)\end{array}$ & $\begin{array}{l}-0.042 \\
(0.029)\end{array}$ & $\begin{array}{c}0.018 \\
(0.015)\end{array}$ \\
\hline
\end{tabular}

Notes: This table shows the robustness of effect of the free movement policy on firm outcomes with alternative standard errors. All panels contain separate regressions of our baseline models specification (1) based on the IS data (see Table 4 for information). In panel A, standard errors are clustered on the level of commuting zone (our baseline strategy). In panels B, C, and D standard errors are clustered on the firm, cantonal and two-digit industry (NACE rev. 2) level, respectively. In panel E, we report standard errors based on the Spatial Heteroscedasticity and Autocorrelation Consistent (SHAC) variance estimator proposed by Conley (1999). This estimator allows for correlation between areas that are geographically close but belong to different regional units. Following Dustmann et al. (2017), we use a uniform kernel and a bandwidth of 100 kilometers. Transition interactions are included in the regression but omitted for brevity. All regressions account for establishment/firm fixed effects, period fixed effects, and linear trends per NUTS-II region. ${ }^{* * *},{ }^{* *},{ }^{*}$, denote statistical significance at the $1 \%, 5 \%$ and $10 \%$ level, respectively. 
Table A.16: Sensitivity of results based on innovation surveys to weighting

\begin{tabular}{|c|c|c|c|c|c|c|c|c|}
\hline VARIABLES & $\begin{array}{c}(1) \\
\text { FE } \\
\text { FTE (ln) }\end{array}$ & $\begin{array}{c}(2) \\
\text { FE } \\
\text { FTE (ln) }\end{array}$ & $\begin{array}{c}(3) \\
\text { FE } \\
\text { Sales }\end{array}$ & $\begin{array}{c}(4) \\
\text { FE } \\
\text { Sales }\end{array}$ & $\begin{array}{c}(5) \\
\text { FE } \\
\text { Produc- } \\
\text { tivity }\end{array}$ & $\begin{array}{c}(6) \\
\text { FE } \\
\text { Produc- } \\
\text { tivity }\end{array}$ & $\begin{array}{c}(7) \\
\text { FE } \\
\text { Patent } \\
\text { appl. 0/1 }\end{array}$ & $\begin{array}{c}\text { (8) } \\
\text { FE } \\
\text { Patent } \\
\text { appl. } 0 / 1\end{array}$ \\
\hline Transition $_{t} * I\left(d_{i} \leq 15\right)$ & $\begin{array}{c}0.015 \\
(0.033)\end{array}$ & $\begin{array}{l}-0.017 \\
(0.080)\end{array}$ & $\begin{array}{c}-0.004 \\
(0.036)\end{array}$ & $\begin{array}{c}0.066 \\
(0.122)\end{array}$ & $\begin{array}{c}-0.001 \\
(0.036)\end{array}$ & $\begin{array}{l}-0.033 \\
(0.143)\end{array}$ & $\begin{array}{c}0.017 \\
(0.019)\end{array}$ & $\begin{array}{c}0.003 \\
(0.036)\end{array}$ \\
\hline Transition $_{t} * I\left(15<d_{i} \leq 30\right)$ & $\begin{array}{c}0.035 \\
(0.029)\end{array}$ & $\begin{array}{l}-0.065 \\
(0.053)\end{array}$ & $\begin{array}{c}-0.008 \\
(0.033)\end{array}$ & $\begin{array}{c}-0.099 \\
(0.082)\end{array}$ & $\begin{array}{l}-0.044 \\
(0.035)\end{array}$ & $\begin{array}{l}-0.117 \\
(0.137)\end{array}$ & $\begin{array}{l}0.004 \\
(0.015)\end{array}$ & $\begin{array}{c}-0.147^{*} \\
(0.078)\end{array}$ \\
\hline Free $_{t} * I\left(d_{i} \leq 15\right)$ & $\begin{array}{c}0.098^{* *} \\
(0.046)\end{array}$ & $\begin{array}{c}0.168 \\
(0.108)\end{array}$ & $\begin{array}{c}0.120^{* *} \\
(0.050)\end{array}$ & $\begin{array}{c}0.435^{* *} \\
(0.176)\end{array}$ & $\begin{array}{c}0.037 \\
(0.035)\end{array}$ & $\begin{array}{c}0.100 \\
(0.080)\end{array}$ & $\begin{array}{c}0.064^{* *} \\
(0.027)\end{array}$ & $\begin{array}{c}0.078^{* *} \\
(0.037)\end{array}$ \\
\hline Free $_{t} * I\left(15<d_{i} \leq 30\right)$ & $\begin{array}{l}0.091^{*} \\
(0.046)\end{array}$ & $\begin{array}{c}0.132 \\
(0.107)\end{array}$ & $\begin{array}{c}0.049 \\
(0.044)\end{array}$ & $\begin{array}{c}-0.139 \\
(0.133)\end{array}$ & $\begin{array}{l}-0.042 \\
(0.039)\end{array}$ & $\begin{array}{l}-0.029 \\
(0.063)\end{array}$ & $\begin{array}{c}0.018 \\
(0.024)\end{array}$ & $\begin{array}{l}-0.179 \\
(0.131)\end{array}$ \\
\hline $\begin{array}{l}\text { Number of firms } \\
\text { Firm effects } \\
\text { Period effects } \\
\text { Nuts-II trends } \\
\text { Weights }\end{array}$ & $\begin{array}{c}10,871 \\
4,422 \\
\sqrt{ } \\
\sqrt{ } \\
\sqrt{ }\end{array}$ & $\begin{array}{c}10,871 \\
4,422 \\
\sqrt{ } \\
\sqrt{ } \\
\sqrt{ } \\
\sqrt{ }\end{array}$ & $\begin{array}{c}10,071 \\
4,198 \\
\sqrt{ } \\
\sqrt{ } \\
\sqrt{ }\end{array}$ & $\begin{array}{c}10,071 \\
4,198 \\
\sqrt{ } \\
\sqrt{ } \\
\sqrt{ } \\
\sqrt{ }\end{array}$ & $\begin{array}{c}8,633 \\
3,770 \\
\sqrt{ } \\
\sqrt{ } \\
\sqrt{ }\end{array}$ & $\begin{array}{c}8,633 \\
3,770 \\
\sqrt{ } \\
\sqrt{ } \\
\sqrt{ } \\
\sqrt{ }\end{array}$ & $\begin{array}{c}10,647 \\
4,372 \\
\sqrt{ } \\
\sqrt{ } \\
\sqrt{ }\end{array}$ & $\begin{array}{c}10,647 \\
4,372 \\
\sqrt{ } \\
\sqrt{ } \\
\sqrt{ } \\
\sqrt{ }\end{array}$ \\
\hline \multicolumn{9}{|c|}{$\begin{array}{l}\text { Notes: The table presents robustness of the results of firm-level regressions specification (1) using the IS } 1996-2013 \text { and } \\
\text { different weighting schemes. The dependent variables are firms' log FTE employment (columns } 1 \text { and } 2 \text { ), } \log \text { total sales } \\
\text { (columns } 3 \text { and 4), log value added per FTE worker (columns } 5 \text { and } 6 \text { ), and a dummy equal to } 1 \text { if a firm filed at least } \\
\text { one patent application in the three years preceding the survey (columns } 7 \text { and } 8 \text { ). The regressions in odd columns are } \\
\text { unweighted, those in even columns are weighted using average firm size (in FTE) as weight. All regressions account for firm } \\
\text { fixed effects, period fixed effects, and linear trends per NUTS-II region. Transition } t \text { is a dummy equal to one between } 1999 \\
\text { and } 2003 \text {, whereas Free } \text { is one from year } 2004 \text { onward. } I\left(d_{i} \leq x\right) \text { and } I\left(y<d_{i} \leq z \text { ) indicate whether a firm is located }\right. \\
\text { less than } x \text { travel minutes or between } y \text { and } z \text { travel minutes from the next border crossing, respectively. Standard errors } \\
\text { are clustered by commuting zone. }{ }^{* * *},{ }^{* *},{ }^{*} \text {, denote statistical significance at the } 1 \%, 5 \% \text { and } 10 \% \text { level, respectively. }\end{array}$} \\
\hline
\end{tabular}


Table A.17: Robustness of firm results to dropping large cities

\begin{tabular}{|c|c|c|c|c|c|c|}
\hline VARIABLES & $\begin{array}{c}(1) \\
\text { FE } \\
\text { Foreign } \\
\text { employ. }\end{array}$ & $\begin{array}{c}(2) \\
\text { FE } \\
\text { Establ. size } \\
\text { BC }\end{array}$ & $\begin{array}{c}(3) \\
\text { FE } \\
\text { Firm size } \\
\text { IS }\end{array}$ & $\begin{array}{l}(4) \\
\mathrm{FE} \\
\text { Sales }\end{array}$ & $\begin{array}{c}(5) \\
\text { FE } \\
\text { Productivity }\end{array}$ & $\begin{array}{c}(6) \\
\text { FE } \\
\text { Patents } \\
0 / 1 \\
\end{array}$ \\
\hline \multicolumn{7}{|c|}{ A. Baseline } \\
\hline Transition $_{t} * I\left(d_{i} \leq 15\right)$ & $\begin{array}{c}0.025^{* * *} \\
(0.009)\end{array}$ & $\begin{array}{c}0.024 \\
(0.017)\end{array}$ & $\begin{array}{c}0.015 \\
(0.033)\end{array}$ & $\begin{array}{l}-0.004 \\
(0.036)\end{array}$ & $\begin{array}{l}-0.001 \\
(0.036)\end{array}$ & $\begin{array}{c}0.017 \\
(0.019)\end{array}$ \\
\hline Transition $_{t} * I\left(15<d_{i} \leq 30\right)$ & $\begin{array}{c}0.031^{* * *} \\
(0.007)\end{array}$ & $\begin{array}{c}0.049^{* * *} \\
(0.016)\end{array}$ & $\begin{array}{c}0.035 \\
(0.029)\end{array}$ & $\begin{array}{l}-0.008 \\
(0.033)\end{array}$ & $\begin{array}{l}-0.044 \\
(0.035)\end{array}$ & $\begin{array}{c}0.004 \\
(0.015)\end{array}$ \\
\hline Free $_{t} * I\left(d_{i} \leq 15\right)$ & $\begin{array}{c}0.085^{* * *} \\
(0.020)\end{array}$ & $\begin{array}{c}0.062^{* * *} \\
(0.022)\end{array}$ & $\begin{array}{c}0.098^{* *} \\
(0.046)\end{array}$ & $\begin{array}{c}0.120^{* *} \\
(0.050)\end{array}$ & $\begin{array}{c}0.037 \\
(0.035)\end{array}$ & $\begin{array}{r}0.064^{* *} \\
(0.027)\end{array}$ \\
\hline Free $_{t} * I\left(15<d_{i} \leq 30\right)$ & $\begin{array}{c}0.034^{* * *} \\
(0.012)\end{array}$ & $\begin{array}{c}0.055^{* *} \\
(0.023)\end{array}$ & $\begin{array}{l}0.091^{*} \\
(0.046)\end{array}$ & $\begin{array}{c}0.049 \\
(0.044)\end{array}$ & $\begin{array}{l}-0.042 \\
(0.039)\end{array}$ & $\begin{array}{c}0.018 \\
(0.024)\end{array}$ \\
\hline \multicolumn{7}{|c|}{ B. Dropping Geneva } \\
\hline Transition $_{t} * I\left(d_{i} \leq 15\right)$ & $\begin{array}{c}0.030^{* * *} \\
(0.010)\end{array}$ & $\begin{array}{l}0.028 \\
(0.021)\end{array}$ & $\begin{array}{c}0.017 \\
(0.035)\end{array}$ & $\begin{array}{l}-0.012 \\
(0.036)\end{array}$ & $\begin{array}{c}0.005 \\
(0.037)\end{array}$ & $\begin{array}{c}0.016 \\
(0.020)\end{array}$ \\
\hline Transition $_{t} * I\left(15<d_{i} \leq 30\right)$ & $\begin{array}{c}0.031^{* * *} \\
(0.008)\end{array}$ & $\begin{array}{c}0.049^{* * *} \\
(0.016)\end{array}$ & $\begin{array}{c}0.035 \\
(0.029)\end{array}$ & $\begin{array}{l}-0.008 \\
(0.033)\end{array}$ & $\begin{array}{l}-0.044 \\
(0.035)\end{array}$ & $\begin{array}{c}0.004 \\
(0.015)\end{array}$ \\
\hline Free $_{t} * I\left(d_{i} \leq 15\right)$ & $\begin{array}{c}0.091^{* * *} \\
(0.025)\end{array}$ & $\begin{array}{c}0.059^{* *} \\
(0.024)\end{array}$ & $\begin{array}{l}0.101^{* *} \\
(0.048)\end{array}$ & $\begin{array}{r}0.107^{* *} \\
(0.049)\end{array}$ & $\begin{array}{c}0.043 \\
(0.036)\end{array}$ & $\begin{array}{r}0.069^{* *} \\
(0.026)\end{array}$ \\
\hline Free $_{t} * I\left(15<d_{i} \leq 30\right)$ & $\begin{array}{c}0.034^{* * *} \\
(0.013)\end{array}$ & $\begin{array}{l}0.055^{* *} \\
(0.023)\end{array}$ & $\begin{array}{l}0.091^{*} \\
(0.046)\end{array}$ & $\begin{array}{c}0.049 \\
(0.044)\end{array}$ & $\begin{array}{l}-0.042 \\
(0.039)\end{array}$ & $\begin{array}{c}0.018 \\
(0.024)\end{array}$ \\
\hline \multicolumn{7}{|c|}{ C. Dropping Basel } \\
\hline Transition $_{t} * I\left(d_{i} \leq 15\right)$ & $\begin{array}{c}0.024^{* * *} \\
(0.009)\end{array}$ & $\begin{array}{l}0.034^{* *} \\
(0.015)\end{array}$ & $\begin{array}{c}0.019 \\
(0.035)\end{array}$ & $\begin{array}{l}-0.003 \\
(0.039)\end{array}$ & $\begin{array}{l}-0.007 \\
(0.037)\end{array}$ & $\begin{array}{c}0.009 \\
(0.019)\end{array}$ \\
\hline Transition $_{t} * I\left(15<d_{i} \leq 30\right)$ & $\begin{array}{c}0.031^{* * *} \\
(0.008)\end{array}$ & $\begin{array}{c}0.049^{* * *} \\
(0.016)\end{array}$ & $\begin{array}{c}0.035 \\
(0.029)\end{array}$ & $\begin{array}{l}-0.008 \\
(0.033)\end{array}$ & $\begin{array}{l}-0.044 \\
(0.035)\end{array}$ & $\begin{array}{c}0.004 \\
(0.015)\end{array}$ \\
\hline Free $_{t} * I\left(d_{i} \leq 15\right)$ & $\begin{array}{c}0.080^{* * *} \\
(0.021)\end{array}$ & $\begin{array}{c}0.067^{* * * *} \\
(0.022)\end{array}$ & $\begin{array}{l}0.093^{*} \\
(0.048)\end{array}$ & $\begin{array}{c}0.113^{* *} \\
(0.053)\end{array}$ & $\begin{array}{c}0.034 \\
(0.037)\end{array}$ & $\begin{array}{r}0.057^{* *} \\
(0.028)\end{array}$ \\
\hline Free $_{t} * I\left(15<d_{i} \leq 30\right)$ & $\begin{array}{c}0.034^{* * *} \\
(0.012)\end{array}$ & $\begin{array}{c}0.054^{* *} \\
(0.022)\end{array}$ & $\begin{array}{l}0.091^{*} \\
(0.046)\end{array}$ & $\begin{array}{c}0.049 \\
(0.044)\end{array}$ & $\begin{array}{l}-0.042 \\
(0.039)\end{array}$ & $\begin{array}{c}0.018 \\
(0.024)\end{array}$ \\
\hline \multicolumn{7}{|c|}{ D. Dropping Lugano } \\
\hline Transition $_{t} * I\left(d_{i} \leq 15\right)$ & $\begin{array}{c}0.025^{* * *} \\
(0.008)\end{array}$ & $\begin{array}{c}0.023 \\
(0.017)\end{array}$ & $\begin{array}{c}0.009 \\
(0.032)\end{array}$ & $\begin{array}{l}-0.011 \\
(0.034)\end{array}$ & $\begin{array}{l}-0.000 \\
(0.036)\end{array}$ & $\begin{array}{c}0.018 \\
(0.019)\end{array}$ \\
\hline Transition $_{t} * I\left(15<d_{i} \leq 30\right)$ & $\begin{array}{c}0.031^{* * *} \\
(0.007)\end{array}$ & $\begin{array}{c}0.049^{* * *} \\
(0.016)\end{array}$ & $\begin{array}{c}0.035 \\
(0.029)\end{array}$ & $\begin{array}{l}-0.008 \\
(0.033)\end{array}$ & $\begin{array}{l}-0.044 \\
(0.035)\end{array}$ & $\begin{array}{c}0.004 \\
(0.015)\end{array}$ \\
\hline Free $_{t} * I\left(d_{i} \leq 15\right)$ & $\begin{array}{c}0.084^{* * *} \\
(0.020)\end{array}$ & $\begin{array}{c}0.061^{* * *} \\
(0.022)\end{array}$ & $\begin{array}{c}0.096^{* *} \\
(0.046)\end{array}$ & $\begin{array}{r}0.116^{* *} \\
(0.050)\end{array}$ & $\begin{array}{c}0.034 \\
(0.035)\end{array}$ & $\begin{array}{r}0.066^{* *} \\
(0.027)\end{array}$ \\
\hline Free $_{t} * I\left(15<d_{i} \leq 30\right)$ & $\begin{array}{c}0.034^{* * *} \\
(0.012)\end{array}$ & $\begin{array}{c}0.055^{* *} \\
(0.023)\end{array}$ & $\begin{array}{l}0.091^{*} \\
(0.046)\end{array}$ & $\begin{array}{c}0.049 \\
(0.044)\end{array}$ & $\begin{array}{l}-0.042 \\
(0.039)\end{array}$ & $\begin{array}{c}0.018 \\
(0.024)\end{array}$ \\
\hline \multicolumn{7}{|c|}{ E. Dropping Zurich } \\
\hline Transition $_{t} * I\left(d_{i} \leq 15\right)$ & $\begin{array}{c}0.025^{* * *} \\
(0.009)\end{array}$ & $\begin{array}{l}0.027 \\
(0.017)\end{array}$ & $\begin{array}{c}0.021 \\
(0.034)\end{array}$ & $\begin{array}{l}-0.002 \\
(0.037)\end{array}$ & $\begin{array}{l}-0.001 \\
(0.038)\end{array}$ & $\begin{array}{c}0.023 \\
(0.019)\end{array}$ \\
\hline Transition $_{t} * I\left(15<d_{i} \leq 30\right)$ & $\begin{array}{c}0.028^{* * *} \\
(0.009)\end{array}$ & $\begin{array}{c}0.047^{* *} \\
(0.018)\end{array}$ & $\begin{array}{c}0.035 \\
(0.032)\end{array}$ & $\begin{array}{l}-0.023 \\
(0.034)\end{array}$ & $\begin{array}{l}-0.047 \\
(0.039)\end{array}$ & $\begin{array}{l}0.007 \\
(0.017)\end{array}$ \\
\hline Free $_{t} * I\left(d_{i} \leq 15\right)$ & $\begin{array}{c}0.084^{* * * *} \\
(0.021)\end{array}$ & $\begin{array}{c}0.067 * * * \\
(0.022)\end{array}$ & $\begin{array}{l}0.095^{*} \\
(0.049)\end{array}$ & $\begin{array}{c}0.113^{* *} \\
(0.052)\end{array}$ & $\begin{array}{c}0.042 \\
(0.036)\end{array}$ & $\begin{array}{c}0.065^{* *} \\
(0.028)\end{array}$ \\
\hline Free $_{t} * I\left(15<d_{i} \leq 30\right)$ & $\begin{array}{c}0.033^{* *} \\
(0.015)\end{array}$ & $\begin{array}{c}0.068^{* * *} \\
(0.023)\end{array}$ & $\begin{array}{c}0.084 \\
(0.051)\end{array}$ & $\begin{array}{c}0.042 \\
(0.048) \\
\end{array}$ & $\begin{array}{l}-0.033 \\
(0.044)\end{array}$ & $\begin{array}{c}0.015 \\
(0.027)\end{array}$ \\
\hline
\end{tabular}

Notes: This table shows the robustness of effect of the free movement policy on firm/establishment outcomes using alternative sample restrictions. Each panel contains separate regressions of our baseline firm/establishment-level specification 1 using the BC (columns 1 and 2) and the IS (columns 3-6). All regressions account for establishment (BC) or firm (IS) fixed effects, period fixed effects, and linear trends per NUTS-II region. The dependent variable in column 1 is full-time equivalent (FTE) employment of foreigners as a share of total employment in 1998. The dependent variable in column 2 is establishments' log FTE employment. The dependent variable in column 3 is firms' log FTE employment. The dependent variable in column 4 is firms' log total sales. The dependent variable in column 5 is firms' log value added per FTE worker. The dependent variable in column 6 is a dummy equal to 1 if a firm filed at least one patent application in the three years preceding the survey. In each panel, we drop observations from a particular city case by case. Standard errors are clustered by commuting zone. ${ }^{* * *} \mathrm{p}<0.01,{ }^{* *} \mathrm{p}<0.05,{ }^{*} \mathrm{p}<0.1$. 
Table A.18: Effect of free movement policy on different innovation outcomes by pre-reform shortage of R\&D workers

\begin{tabular}{|c|c|c|c|c|c|c|c|}
\hline VARIABLES & $\begin{array}{c}(1) \\
R \& D \\
0 / 1\end{array}$ & $\begin{array}{c}(2) \\
\text { R\&D } \\
\text { workers } \\
\text { IHS }\end{array}$ & $\begin{array}{c}(3) \\
\text { R\&D } \\
\text { expend. } \\
\text { IHS }\end{array}$ & $\begin{array}{c}(4) \\
\text { Patent } \\
\text { appl. } \\
0 / 1\end{array}$ & $\begin{array}{c}(5) \\
\text { Process } \\
\text { innov. } \\
0 / 1 \\
\end{array}$ & $\begin{array}{c}(6) \\
\text { Product } \\
\text { innov. } \\
0 / 1\end{array}$ & $\begin{array}{c}(7) \\
\text { Sales share } \\
\text { new/impr. } \\
\text { products }\end{array}$ \\
\hline Free $_{t} * I\left(d_{i} \leq 15\right)$ & $\begin{array}{c}-0.034 \\
(0.039)\end{array}$ & $\begin{array}{l}-0.058 \\
(0.099)\end{array}$ & $\begin{array}{l}-0.599 \\
(0.575)\end{array}$ & $\begin{array}{c}0.082^{* *} \\
(0.035)\end{array}$ & $\begin{array}{c}0.012 \\
(0.047)\end{array}$ & $\begin{array}{l}-0.062 \\
(0.048)\end{array}$ & $\begin{array}{l}-0.033 \\
(0.029)\end{array}$ \\
\hline Free $_{t} * I\left(d_{i} \leq 15\right) * R \& D_{i}^{\text {short }}$ & $\begin{array}{c}0.109 \\
(0.066)\end{array}$ & $\begin{array}{c}0.364^{* *} \\
(0.143)\end{array}$ & $\begin{array}{l}1.511^{* *} \\
(0.689)\end{array}$ & $\begin{array}{l}0.073^{*} \\
(0.042)\end{array}$ & $\begin{array}{l}-0.032 \\
(0.067)\end{array}$ & $\begin{array}{c}0.216^{* * *} \\
(0.063)\end{array}$ & $\begin{array}{c}0.107^{* *} \\
(0.053)\end{array}$ \\
\hline Free $_{t} * I\left(15<d_{i} \leq 30\right)$ & $\begin{array}{l}-0.007 \\
(0.037)\end{array}$ & $\begin{array}{c}0.125 \\
(0.085)\end{array}$ & $\begin{array}{c}0.225 \\
(0.488)\end{array}$ & $\begin{array}{c}0.038 \\
(0.030)\end{array}$ & $\begin{array}{l}-0.087^{*} \\
(0.047)\end{array}$ & $\begin{array}{l}-0.013 \\
(0.032)\end{array}$ & $\begin{array}{l}-0.033 \\
(0.029)\end{array}$ \\
\hline Free $_{t} * I\left(15<d_{i} \leq 30\right) * R \& D_{i}^{\text {short }}$ & $\begin{array}{l}-0.000 \\
(0.049)\end{array}$ & $\begin{array}{l}-0.131 \\
(0.115)\end{array}$ & $\begin{array}{l}-0.600 \\
(0.734)\end{array}$ & $\begin{array}{c}0.051 \\
(0.043)\end{array}$ & $\begin{array}{c}0.085 \\
(0.063)\end{array}$ & $\begin{array}{c}0.059 \\
(0.062)\end{array}$ & $\begin{array}{l}-0.004 \\
(0.059)\end{array}$ \\
\hline Observations & 4,967 & 4,473 & 4,358 & 4,904 & 4,985 & 4,985 & 2,802 \\
\hline R-squared & 0.030 & 0.022 & 0.016 & 0.021 & 0.050 & 0.026 & 0.040 \\
\hline Number of firms & 1,560 & 1,513 & 1,480 & 1,557 & 1,560 & 1,560 & 1,245 \\
\hline Firm effects & $\sqrt{ }$ & $\sqrt{ }$ & $\sqrt{ }$ & $\sqrt{ }$ & $\sqrt{ }$ & $\sqrt{ }$ & $\sqrt{ }$ \\
\hline Period effects & $\sqrt{ }$ & $\sqrt{ }$ & $\sqrt{ }$ & $\sqrt{ }$ & $\sqrt{ }$ & $\sqrt{ }$ & $\sqrt{ }$ \\
\hline Nuts-II trends & $\sqrt{ }$ & $\sqrt{ }$ & $\sqrt{ }$ & $\sqrt{ }$ & $\sqrt{ }$ & $\sqrt{ }$ & $\sqrt{ }$ \\
\hline
\end{tabular}

Notes: The table presents results of firm-level regressions specification (1) using the IS 1996-2013 and exploiting heterogeneity with respect to pre-reform shortage of R\&D workers. The dependent variable in column 1 is a dummy equal to one if a firm reports to have R\&D activity. The dependent variables in columns 2 and 3 are the Inverse Hyperbolic Sines (IHS) of the number of $R \& D$ workers and $R \& D$ expenditures, respectively. The dependent variable in column 4 is a dummy equal to 1 if a firm filed at least one patent application in the three years preceding the survey. The dependent variables in columns 5 and 6 are dummies equal to one if a firm reports to have introduced at least one process or product innovation in the three years preceding the survey. Process innovation refers to the implementation of a new or significantly improved production or delivery method. A product innovation is defined as the introduction of a good or service that is either new or a substantially improved version of a prior good or service. The dependent variable in column 7 is the firms' sales share of new or significantly improved products. All regressions account for firm fixed effects, period fixed effects, and linear trends per NUTS-II region. Free $e_{t}$ is a dummy equal to one from year 2004 onward. The variables capturing the transition effects are included in the regression but omitted for brevity. $I\left(d_{i} \leq x\right)$ and $I\left(y<d_{i} \leq z\right)$ indicate whether a firm is located less than $x$ travel minutes or between $y$ and $z$ travel minutes from the next border crossing, respectively. $R \& D_{i}^{\text {shortage }}$ is a dummy equal to 1 if a firm reported substantial problems in finding R\&D workers in either one or the two IS in 1996 and 1999 (i.e. if the average of the corresponding original Likert scale survey item is at least 4), or 0 otherwise. Standard errors are clustered by commuting zone. ${ }^{* * *} \mathrm{p}<0.01,{ }^{*} \mathrm{p}<0.05,{ }^{*} \mathrm{p}<0.1$. 
Table A.19: Effect of free movement policy on establishment entry and exit

\begin{tabular}{|c|c|c|c|c|c|c|}
\hline VARIABLES & $\begin{array}{c}(1) \\
\text { Entry } \\
\text { all }\end{array}$ & $\begin{array}{c}(2) \\
\text { Entry } \\
\text { Low- } \\
\text { tech } \\
\text { manuf. }\end{array}$ & $\begin{array}{c}(3) \\
\text { Entry } \\
\text { High- } \\
\text { tech } \\
\text { manuf. }\end{array}$ & $\begin{array}{c}(4) \\
\text { Entry } \\
\text { Knowl.- } \\
\text { intensive } \\
\text { services }\end{array}$ & $\begin{array}{c}(5) \\
\text { Entry } \\
\text { Not knowl.- } \\
\text { intensive } \\
\text { services }\end{array}$ & $\begin{array}{c}(6) \\
\text { Exit } \\
\text { all }\end{array}$ \\
\hline Transition $_{t} * I\left(d_{i} \leq 15\right)$ & $\begin{array}{c}0.016^{* * *} \\
(0.006)\end{array}$ & $\begin{array}{c}0.012 \\
(0.010)\end{array}$ & $\begin{array}{c}0.041^{* *} \\
(0.017)\end{array}$ & $\begin{array}{c}0.018 \\
(0.012)\end{array}$ & $\begin{array}{c}0.009 * * \\
(0.004)\end{array}$ & $\begin{array}{c}-0.004 \\
(0.009)\end{array}$ \\
\hline Transition $_{t} * I\left(15<d_{i} \leq 30\right)$ & $\begin{array}{c}0.016^{* *} \\
(0.007)\end{array}$ & $\begin{array}{c}0.006 \\
(0.008)\end{array}$ & $\begin{array}{c}0.007 \\
(0.017)\end{array}$ & $\begin{array}{c}0.040^{* * *} \\
(0.013)\end{array}$ & $\begin{array}{l}-0.000 \\
(0.005)\end{array}$ & $\begin{array}{l}-0.009 \\
(0.008)\end{array}$ \\
\hline Free $_{t} * I\left(d_{i} \leq 15\right)$ & $\begin{array}{c}0.037^{* * *} \\
(0.010)\end{array}$ & $\begin{array}{c}0.033^{* * *} \\
(0.010)\end{array}$ & $\begin{array}{c}0.056^{* * *} \\
(0.019)\end{array}$ & $\begin{array}{c}0.048^{* * *} \\
(0.014)\end{array}$ & $\begin{array}{c}0.022^{* * *} \\
(0.007)\end{array}$ & $\begin{array}{c}0.002 \\
(0.007)\end{array}$ \\
\hline Free $_{t} * I\left(15<d_{i} \leq 30\right)$ & $\begin{array}{c}0.026^{* * *} \\
(0.004)\end{array}$ & $\begin{array}{c}0.011 \\
(0.009)\end{array}$ & $\begin{array}{c}0.020 \\
(0.012)\end{array}$ & $\begin{array}{c}0.041^{* * *} \\
(0.009)\end{array}$ & $\begin{array}{c}0.017^{* * *} \\
(0.004)\end{array}$ & $\begin{array}{l}-0.003 \\
(0.005)\end{array}$ \\
\hline Observations & 8,157 & 7,284 & 5,135 & 7,602 & 8,055 & 9,764 \\
\hline R-squared & 0.386 & 0.136 & 0.075 & 0.170 & 0.342 & 0.422 \\
\hline Number of municipalities & 1,636 & 1,457 & 1,027 & 1,521 & 1,615 & 1,636 \\
\hline Municipality effects & $\sqrt{ }$ & $\sqrt{ }$ & $\sqrt{ }$ & $\sqrt{ }$ & $\sqrt{ }$ & $\sqrt{ }$ \\
\hline Period effects & $\sqrt{ }$ & $\sqrt{ }$ & $\sqrt{ }$ & $\sqrt{ }$ & $\sqrt{ }$ & $\sqrt{ }$ \\
\hline Nuts-II trends & $\sqrt{ }$ & $\sqrt{ }$ & $\sqrt{ }$ & $\sqrt{ }$ & $\sqrt{ }$ & $\sqrt{ }$ \\
\hline Number of clusters & 73 & 72 & 71 & 73 & 73 & 73 \\
\hline
\end{tabular}

Notes: The table studies whether the immigration reform affected establishment entry and exit. All estimations are run at the municipality level using BC data and are restricted to the BR. The dependent variable in columns 1-5 is the number of new establishments in $t$ as a fraction of the number of establishments in 1998 in the sector. The estimation sample is based on the BC 1991-2008. The dependent variable in columns 6 is the number of establishments exiting between $t-1$ and $t$ as a fraction of the number of establishments in 1998 in the sector. The sample is based on the BC 1991-2011 in this case. All regressions account for municipality fixed effects, period fixed effects, and linear trends per NUTS-II region. Transition $t$ is a dummy equal to one between 1999 and 2003, whereas Freet is one from year 2004 onward. $I\left(d_{i} \leq x\right)$ and $I\left(y<d_{i} \leq z\right)$ indicate whether a firm is located less than $x$ travel minutes or between $y$ and $z$ travel minutes from the next border crossing, respectively. Regressions are weighted using the municipality-specific number of establishments in the sector in 1998 as the weight. Standard errors are clustered by commuting zone. ${ }^{* * *} \mathrm{p}<0.01,{ }^{* *} \mathrm{p}<0.05,{ }^{*} \mathrm{p}<0.1$. 
Table A.20: Effects of free movement policy on within-firm staffing decisions

\begin{tabular}{lcccc}
\hline & $(1)$ & $(2)$ & $(3)$ & $(4)$ \\
& $\begin{array}{c}\text { FE } \\
\text { Foreign } \\
\text { employ. }\end{array}$ & $\begin{array}{c}\text { FE } \\
\text { Foreign } \\
\text { employ. }\end{array}$ & $\begin{array}{c}\text { FE } \\
\text { Establ. } \\
\text { size } \\
(\text { FTE })\end{array}$ & $\begin{array}{c}\text { FE } \\
\text { Establ. } \\
\text { size } \\
(\text { FTE })\end{array}$ \\
VARIABLES & & & & \\
& & & & \\
Transition $_{t} * I\left(d_{i} \leq 15\right)$ & 0.029 & 0.006 & 0.009 & 0.030 \\
& $(0.019)$ & $(0.009)$ & $(0.068)$ & $(0.045)$ \\
Transition $_{t} * I\left(15<d_{i} \leq 30\right)$ & $0.050^{* * *}$ & $0.028^{* * *}$ & 0.093 & $0.089^{* *}$ \\
& $(0.015)$ & $(0.009)$ & $(0.065)$ & $(0.044)$ \\
Free $_{t} * I\left(d_{i} \leq 15\right)$ & $0.062^{* * *}$ & $0.070^{* * *}$ & $0.097^{* *}$ & $0.105^{*}$ \\
& $(0.022)$ & $(0.023)$ & $(0.037)$ & $(0.059)$ \\
Free $_{t} * I\left(15<d_{i} \leq 30\right)$ & $0.042^{* * *}$ & $0.050^{* * *}$ & $0.116^{* *}$ & $0.124^{*}$ \\
& $(0.014)$ & $(0.015)$ & $(0.054)$ & $(0.070)$ \\
& & & & \\
Observations & 54,463 & 66,188 & 72,414 & 88,080 \\
R-squared & 0.592 & 0.581 & 0.728 & 0.698 \\
Preferred sample & $\sqrt{ }$ & $\sqrt{ }$ & $\sqrt{ }$ & $\sqrt{ }$ \\
Region effects & $\sqrt{ }$ & $\sqrt{ }$ & $\sqrt{ }$ & $\sqrt{ }$ \\
Firm-period effects & $\sqrt{ }$ & $\sqrt{ }$ & $\sqrt{ }$ & $\sqrt{ }$ \\
Control group: BR 30+ & $\sqrt{ }$ & & $\sqrt{ }$ & \\
Control group: NBR & & $\sqrt{ }$ & & $\sqrt{ }$ \\
\hline
\end{tabular}

Notes: This table studies whether multi-establishment firms grow disproportionately in establishments closer to the border by including a full set of firm-period effects into the otherwise standard DiD model, specification 1. The effects are thus identified only from the comparison of establishments within the same firm. The estimation sample is private-sector establishments in the BC 1995-2008 (columns 1 and 2) and 1991-2011 (columns 3 and 4). The dependent variable in columns 1 and 2 is full-time equivalent (FTE) employment of foreigners as a share of total employment in 1998. Columns 3 and 4 show the corresponding results using log FTE employment as dependent variable. The regressions do not contain establishment fixed effects. Instead, we control for region fixed effects, i. e. a dummy equal to one for each of the four relevant regions (border region 0-15, 15-30, and 30+ minutes from the border, non-border region). We also relax the restriction that an establishment needs to be present 1991-2011 somewhat (since the number of firms with several establishments present throughout the 20-year period is very small). Instead, we focus on all establishments existing at least in 1995-2005. We observe larger increase the foreign employment share and FTE employment in highly treated establishments relative to establishments further away from the border even within the same firms. Standard errors are clustered by commuting zone. ${ }^{* * *} \mathrm{p}<0.01$, $^{* *} \mathrm{p}<0.05$, $^{*} \mathrm{p}<0.1$. 
Table A.21: Effects of free movement policy on firms' export status

\begin{tabular}{lcccc}
\hline & $(1)$ & $(2)$ & $(3)$ & $(4)$ \\
& FE & FE & FE & $\begin{array}{c}\text { FE } \\
\text { EARIABLES }\end{array}$ \\
& Export 0/1 & Export 0/1 & Export share & Export share \\
\hline Transition $_{t} * I\left(d_{i} \leq 15\right)$ & -0.010 & 0.016 & 0.401 & 0.455 \\
& $(0.027)$ & $(0.022)$ & $(0.898)$ & $(0.887)$ \\
Transition $_{t} * I\left(15<d_{i} \leq 30\right)$ & -0.037 & -0.012 & -0.695 & -0.646 \\
& $(0.025)$ & $(0.019)$ & $(0.898)$ & $(0.821)$ \\
Free $_{t} * I\left(d_{i} \leq 15\right)$ & -0.004 & -0.020 & 0.414 & 0.791 \\
& $(0.020)$ & $(0.022)$ & $(0.951)$ & $(0.792)$ \\
Free $_{t} * I\left(15<d_{i} \leq 30\right)$ & -0.007 & -0.022 & -0.243 & 0.137 \\
& $(0.017)$ & $(0.021)$ & $(0.909)$ & $(0.797)$ \\
& & & & \\
Observations $_{\text {R-squared }}$ & 10,757 & 12,495 & 10,483 & 12,193 \\
Number of firms & 0.003 & 0.003 & 0.010 & 0.008 \\
Preferred sample & 4,400 & 5,129 & 4,341 & 5,062 \\
Firm effects & $\sqrt{ }$ & $\sqrt{ }$ & $\sqrt{ }$ & $\sqrt{ }$ \\
Period effects & $\sqrt{ }$ & $\sqrt{ }$ & $\sqrt{ }$ & $\sqrt{ }$ \\
Control group: BR 30+ & $\sqrt{ }$ & $\sqrt{ }$ & $\sqrt{ }$ & $\sqrt{ }$ \\
Control group: NBR & $\sqrt{ }$ & $\sqrt{ }$ & $\sqrt{ }$ & $\sqrt{ }$ \\
\hline
\end{tabular}

Notes: The table studies the effect of the free movement policy an firm's export status based on firm-level specification 1 and the IS 1996-2013 using both control groups. The dependent variable in columns 1 and 2 is a dummy equal to one if a firm exported in the year before the survey. The dependent variable in columns 3 and 4 is firms' export share in sales in the year before the survey. Transition $t$ is a dummy equal to one between 1999 and 2003, whereas Freet is one from year 2004 onward. $I\left(d_{i} \leq x\right)$ and $I\left(y<d_{i} \leq z\right)$ indicate whether a firm is located less than $x$ travel minutes or between $y$ and $z$ travel minutes from the next border crossing, respectively. All regressions account for firm fixed effects, period fixed effects, and linear trends per NUTS-II region. Standard errors are clustered by commuting zone. ${ }^{* * *},{ }^{* *},{ }^{*}$, denote statistical significance at the $1 \%, 5 \%$ and $10 \%$ level, respectively. 


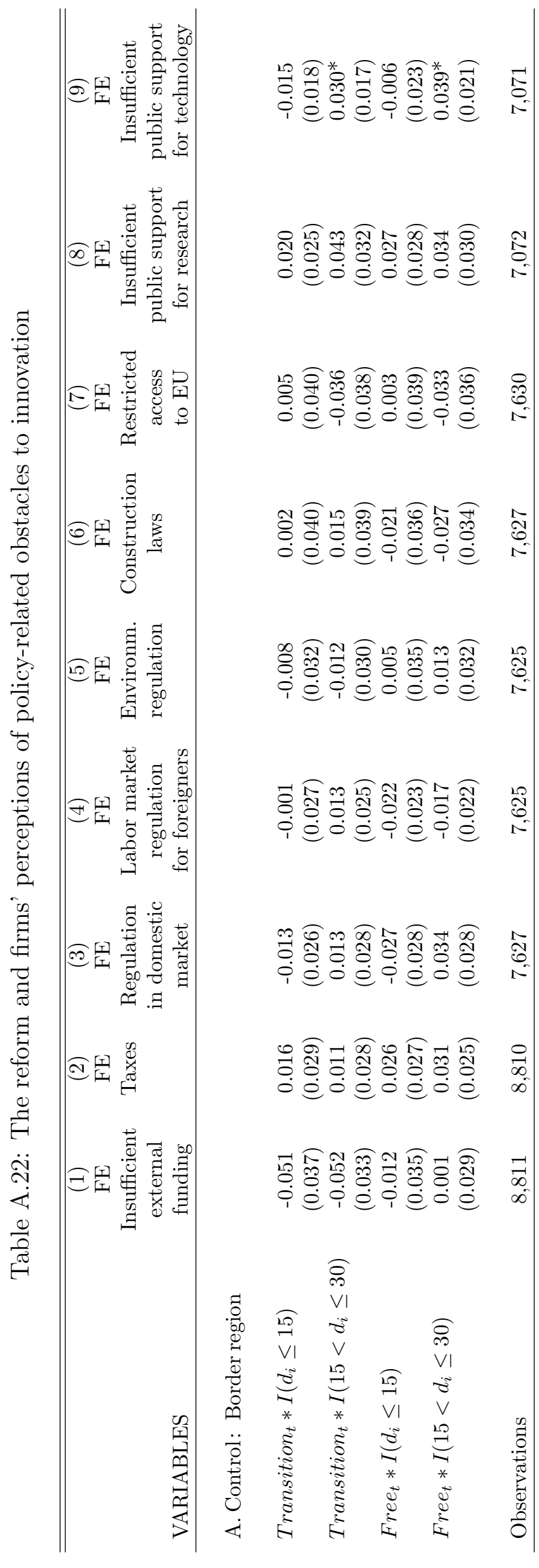

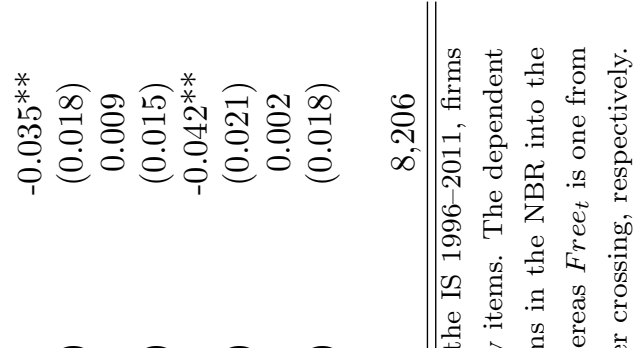



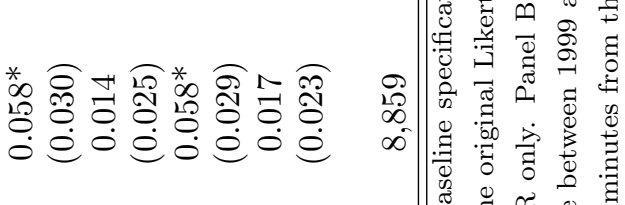

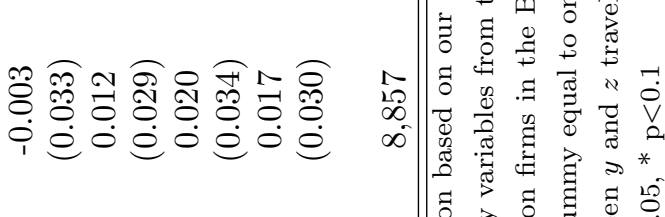

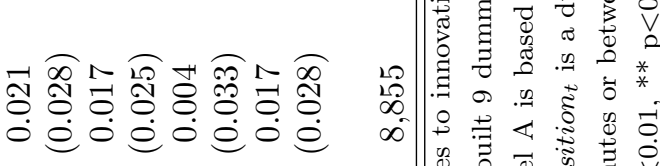

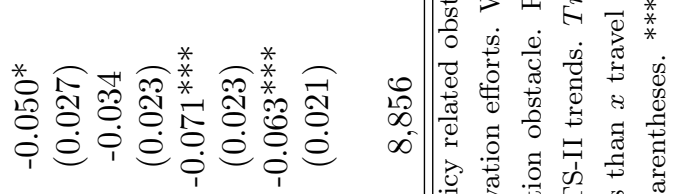

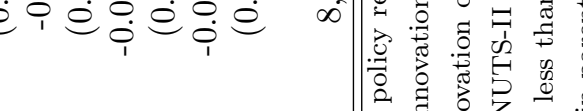



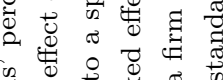

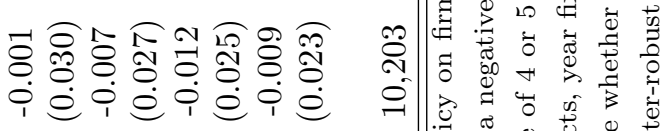



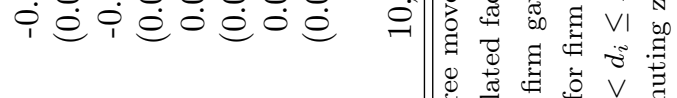

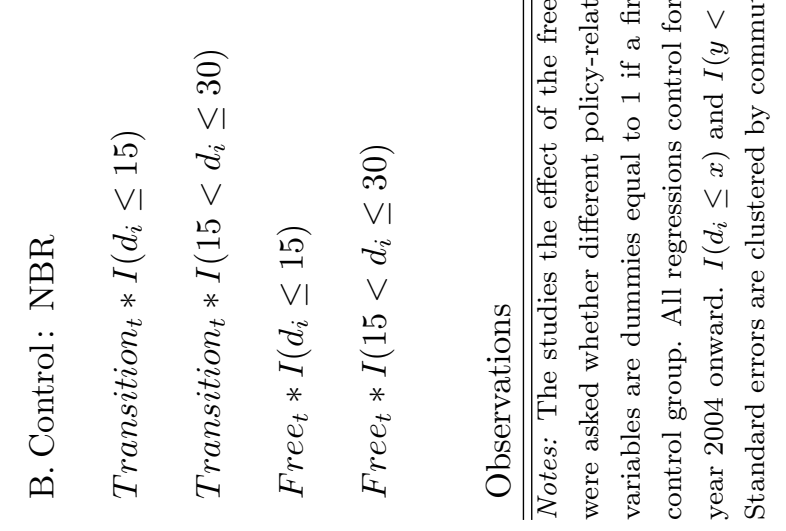


Table A.23: Effect of the free movement policy on share and number of natives in top tier management

\begin{tabular}{|c|c|c|c|c|}
\hline \multirow[t]{2}{*}{$\overline{\text { Dependent variable }}$} & \multicolumn{2}{|c|}{ Share board members } & \multicolumn{2}{|c|}{ Log (board members) } \\
\hline & $(1)$ & $(2)$ & $(3)$ & $(4)$ \\
\hline \multicolumn{5}{|c|}{ A. All education groups } \\
\hline Freet $_{t} \cdot I\left(d_{m} \leq 15\right)$ & $\begin{array}{c}0.020 \\
(0.014)\end{array}$ & $\begin{array}{l}0.030^{*} \\
(0.016)\end{array}$ & $\begin{array}{c}0.130 \\
(0.091)\end{array}$ & $\begin{array}{r}0.199^{* *} \\
(0.076)\end{array}$ \\
\hline Free $_{t} \cdot I\left(15<d_{m} \leq 30\right)$ & $\begin{array}{l}-0.005 \\
(0.012)\end{array}$ & $\begin{array}{c}0.006 \\
(0.012)\end{array}$ & $\begin{array}{c}0.066 \\
(0.101)\end{array}$ & $\begin{array}{r}0.139^{* *} \\
(0.059)\end{array}$ \\
\hline Mean Dep. Var. pre-period & 0.218 & 0.213 & & \\
\hline \multicolumn{5}{|c|}{ B. Highly educated } \\
\hline Freet $_{t} \cdot I\left(d_{m} \leq 15\right)$ & $\begin{array}{l}0.072^{*} \\
(0.039)\end{array}$ & $\begin{array}{l}0.078^{*} \\
(0.041)\end{array}$ & $\begin{array}{l}0.230^{*} \\
(0.121)\end{array}$ & $\begin{array}{c}0.249^{* *} \\
(0.123)\end{array}$ \\
\hline Free $_{t} \cdot I\left(15<d_{m} \leq 30\right)$ & $\begin{array}{c}-0.003 \\
(0.032) \\
0.386\end{array}$ & $\begin{array}{c}0.011 \\
(0.036) \\
0.382\end{array}$ & $\begin{array}{l}0.109 \\
(0.130)\end{array}$ & $\begin{array}{c}0.123 \\
(0.120)\end{array}$ \\
\hline \multicolumn{5}{|c|}{ C. Low educated } \\
\hline Freet $_{t} \cdot I\left(d_{m} \leq 15\right)$ & $\begin{array}{l}-0.006 \\
(0.014)\end{array}$ & $\begin{array}{c}0.012 \\
(0.016)\end{array}$ & $\begin{array}{l}-0.038 \\
(0.094)\end{array}$ & $\begin{array}{c}0.065 \\
(0.083)\end{array}$ \\
\hline Free $_{t} \cdot I\left(15<d_{m} \leq 30\right)$ & $\begin{array}{l}-0.015 \\
(0.013)\end{array}$ & $\begin{array}{c}0.001 \\
(0.013)\end{array}$ & $\begin{array}{l}-0.014 \\
(0.104)\end{array}$ & $\begin{array}{l}0.082 \\
(0.084)\end{array}$ \\
\hline Mean Dep. Var. pre-period & 0.169 & 0.168 & & \\
\hline $\begin{array}{l}\text { Control group: BR } 30+ \\
\text { Control group: NBR }\end{array}$ & $\sqrt{ }$ & $\sqrt{ }$ & $\sqrt{ }$ & $\sqrt{ }$ \\
\hline $\begin{array}{l}\text { Year/Area fixed effects } \\
\text { Nuts-II trends }\end{array}$ & $\sqrt{ }$ & $\sqrt{ }$ & $\sqrt{ }$ & $\sqrt{ }$ \\
\hline
\end{tabular}

Notes: This table shows the effect of the free movement policy on the share and the number of natives who are board members of firms based on regression specification (1). The dependent variable in column 1-2 is the share of native workers who are board members within an education group. In column 3 and 4 , the dependent variable is $\log$ number of native board members or their full-time equivalents, respectively, by education group. Freet is one for municipalities in the border region after 2004. $\left(d_{i} \leq x\right)$ and $\left(y<d_{i} \leq z\right)$ indicate whether a municipality is located less than $x$ travel minutes or between $y$ and $z$ travel minutes from the next border crossing, respectively. Distance interactions with the transition phase are omitted for brevity. Regressions are weighted using the total number of natives in a cell. The share of board members in each panel is computed using the pre-1999 average in each panel. Robust standard errors, clustered by commuting zone, are given in parentheses. ${ }^{* * *},{ }^{* *},{ }^{*}$, denote statistical significance at the $1 \%, 5 \%$ and $10 \%$ level, respectively. SLFS data 1996-2010. 
Table A.24: Effect of the free movement policy on wages of highly educated natives in different management ranks (control group: NBR)

Dependent variable: Average log hourly wages of highly educated natives in management ranks

\begin{tabular}{|c|c|c|c|c|}
\hline & \multirow{2}{*}{$\begin{array}{l}\text { All highly } \\
\text { educated }\end{array}$} & \multicolumn{2}{|c|}{ Wage by manag. rank } & \multirow{2}{*}{$\begin{array}{c}\text { constant manag. } \\
\text { rank shares }\end{array}$} \\
\hline & & high and middle & low and no & \\
\hline & $(1)$ & $(2)$ & $(3)$ & $(4)$ \\
\hline Free $_{t} \cdot I\left(d_{m} \leq 15\right)$ & $\begin{array}{c}0.043^{* * *} \\
(0.013)\end{array}$ & $\begin{array}{c}0.051^{* * *} \\
(0.018)\end{array}$ & $\begin{array}{c}0.032^{* * *} \\
(0.011)\end{array}$ & $\begin{array}{c}0.029^{* * *} \\
(0.010)\end{array}$ \\
\hline Free $_{t} \cdot I\left(15<d_{m} \leq 30\right)$ & $\begin{array}{l}0.018^{*} \\
(0.010)\end{array}$ & $\begin{array}{c}0.024 \\
(0.015)\end{array}$ & $\begin{array}{c}0.013 \\
(0.012)\end{array}$ & $\begin{array}{c}0.008 \\
(0.010)\end{array}$ \\
\hline $\begin{array}{l}\text { Year/Area fixed effects } \\
\text { Nuts II trend }\end{array}$ & $\sqrt{ }$ & $\sqrt{ }$ & $\begin{array}{l}\sqrt{ } \\
\sqrt{ }\end{array}$ & $\sqrt{ }$ \\
\hline
\end{tabular}

Notes: This table shows the effect of the free movement policy on mean log hourly real wages of highly educated natives in different management levels based on equation (1). Municipalities in the NBR constitute the control group. Column 1 reports the baseline effect on all highly educated natives. In column 2 and 3, highly educated natives are split into those with a high or middle positions and low or no management rank, respectively. Column 4 reports the effect on all highly educated when the share of high/middle managers is hold at its 1998 level. This variable is the weighted average of the wages in high/middle positions $p, w_{m, t}^{p=h}$ and wages in low/no management positions, $w_{m, t}^{p=l}$ using the share of these groups' employment in 1998, $\gamma_{m,{ }^{\prime} 98}=L^{p=h} / L$ and $\left(1-\gamma_{m,{ }^{\prime} 98}\right)$, as weights i.e. $\tilde{w}_{m, t}=w_{m, t}^{p=h} \gamma_{m,{ }^{\prime} 98}+w_{m, t}^{p=l}\left(1-\gamma_{m},^{\prime} 98\right)$. Free $e_{t}$ is one from year 2004 onward. $\left(d_{i} \leq x\right)$ and $\left(y<d_{i} \leq z\right)$ indicate whether a municipality is located less than $x$ travel minutes or between $y$ and $z$ travel minutes from the next border crossing, respectively. Distance interactions with the transition phase are omitted for brevity. Regressions are weighted using the total number of natives in a cell. Robust standard errors, clustered by commuting zone, are given in parentheses. ${ }^{* * *},{ }^{* *},{ }^{*}$, denote statistical significance at the $1 \%, 5 \%$ and $10 \%$ level, respectively. 


\section{References: Appendix}

Beerli, Andreas, Ronald Indergand, and Johannes Kunz, "The Supply of Foreign Talent: How Skill-Biased Technology Drives the Skill Mix of Immigrants," KOF Working Papers, No. 436, 2017.

Conley, Timothy G., "GMM estimation with cross sectional dependence," Journal of Econometrics, 1999, 92 (1), 1-45.

Dustmann, Christian, Uta Schönberg, and Jan Stuhler, "Labor Supply Shock and the Dynamics of Local Wages and Employment," The Quarterly Journal of Economics, 2017, 132 (1), 435-483.

Henneberger, Fred and Alexandre Ziegler, "Empirische Überprüfung des Auftretens von Lohndruck aufgrund des Immigrationsdrucks aus den EU17/EFTA-Mitgliedstaaten," Diskussionspapiere des Forschungsinstituts für Arbeit und Arbeitsrecht an der Universität St. Gallen No. 125, 2011.

Losa, Fabio Beniamino, Maurizio Bigotta, and Gonzalez Oscar, "La libre circulation: joies ou douleurs?," Technical Report 2014.

Puhani, Patrick A., "Relative supply and demand for skills in Switzerland," Swiss Journal of Economics and Statistics, 2005, 141 (4), 555-584.

Siegenthaler, Michael, Michael Graff, and Massimo Mannino, "The Swiss "Job Miracle"," Review of Economics, 2016, 67 (1), 53-89. 